\title{
(ख)
}

AUTARQUIA ASSOCIADA À UNIVERSIDADE DE SÃO PAULO

\section{AVALIAÇÃO MORFOLÓGICA E BIOMECÂNICA DOS EFEITOS DA RADIAÇÃO GAMA EM OSSO HUMANO LIOFILIZADO OU CONGELADO}

\author{
STEFANY PLUMERI SANTIN
}

Dissertação apresentada como parte dos requisitos para obtenção do Grau de Mestre em Ciências na Área de Tecnologia Nuclear - Aplicações

Orientadora:

Profa. Dra. Monica Beatriz Mathor 
INSTITUTO DE PESQUISAS ENERGÉTICAS E NUCLEARES

Autarquia associada à Universidade de São Paulo

\title{
AVALIAÇÃO MORFOLÓGICA E BIOMECÂNICA DOS EFEITOS DA RADIAÇÃO GAMA EM OSSO HUMANO LIOFILIZADO OU CONGELADO
}

\author{
STEFANY PLUMERI SANTIN
}

Dissertação apresentada como parte dos requisitos para obtenção do Grau de Mestre em Ciências na Área de Tecnologia Nuclear - Aplicações

Orientadora:

Profa. Dra. Monica Beatriz Mathor

Versão Corrigida

Versão Original disponível no IPEN

São Paulo

2014 


\section{DEDICATÓRIA}

Dedico este trabalho aos meus pais Sandra Plumeri Santin e Caetano Paulo Santin que sempre me incentivaram e apoiaram em todos os meus estudos e principalmente, na realização deste trabalho. Ao querido Carlos Eduardo Paschoal de Almeida por ser meu grande companheiro e ter me incentivado a progredir. 
Agradecimentos

À Dra. Monica Beatriz Mathor, por todo profissionalismo, sabedoria, ensinamentos e por ter me incentivado, dando credibilidade para eu ter autonomia. Agradeço também pela amizade, carinho e momentos de descontração. Obrigada por ter proporcionado meu crescimento pessoal e profissional.

Ao Dr. Antonio Carlos Martinho Junior, sou grata por ter me indicado para a iniciação científica, onde adquiri conhecimento para progredir. Foram diversos ensinamentos que me levaram a crescer e seguir na área acadêmica. Agradeço também pela amizade, momentos de descontração e por todos os conselhos.

Ao Augusto Luís Ubirajara dos Santos por ter me recebido e participado do projeto. Obrigada por ter sido sempre solicito, pela enorme ajuda durante 0 processamento e direcionamento deste trabalho.

Ao Dr. Anderson Zanardi de Freitas pela participação no projeto e pelo apoio. Agradeço também por todo incentivo, ajuda durante os ensaios, sugestões, diversos ensinamentos, momentos de descontração e por hoje ser um grande amigo que eu admiro.

Ao Dr. Eddy Segura Pino por ter sido presente nos momentos de dúvidas, disponibilidade, por todos os ensinamentos com respeito aos ensaios mecânicos e principalmente pela incansável ajuda. Obrigada!

Ao Djalma Batista Dias por todo aprendizado, apoio e pela ajuda durante os testes na Instron.

Ao Dr. Igor Carvalho e ao João Lucas da Horiba por me apresentarem a espectroscopia Raman e por disponibilizarem o equipamento todas as vezes que solicitei. Obrigada pela enorme compreensão!

Aos meus amigos do laboratório que durante a realização do meu trabalho fizeram meus dias mais felizes, à Patricia S. Lopes por ser tão carinhosa e sempre nos agradar, Fernando A. Neves Soares por todo apoio, profissionalismo e amizade, à Dayane Piffer Luco pelos momentos de descontração, apoio e companhia, ao Leonardo D. P. Dornelles pela ajuda e por ter sido nosso estagiário 
muito competente, ao Nelson Mendes pela sua calma e amizade, à Marcelly Umemura pelo seu jeito meigo, à Bianca Genesi por ter nos divertidos, à Daniele Steffens pela amizade, à Silvana Altran, ao Tiago por todos ensinamentos e amizade e à Fátima por todo apoio.

À Dra. Luci Diva Brocardo por ter disponibilizado o colorímetro para a realização dos ensaios.

À equipe do Banco Musculoesquelético do Hospital das Clínicas da Universidade de São Paulo. Em especial, a Graziela Maragni, Maria Aparecida Guedes, Ligia Machado e Lucas Silva por todo apoio.

Ao Uri Antebi por todo conhecimento compartilhado, amizade e parcerias.

As grandes amigas que fizeram os meus dias mais felizes, Daniele Yoshito por ter me recebido com tanto carinho e por ter me proporcionado ensinamentos valiosos, Natália Mencacci Esteves-Pedro por sua sensibilidade, conselhos e por ser um exemplo de bondade e Bianca Sufi da Silva por ter me ensinado a nunca desistir e pela sua fé incomparável!

Ao Rodrigo Crespo Mosca que solicitou três páginas merecidas de agradecimentos, mas não posso me estender muito, obrigada por tudo! Agradeço por me ter como uma irmã e ser um grande amigo que sempre me apoiou nos momentos mais difíceis, com palavras acolhedoras e com muito carinho.

Aos amigos do CQMA, à grande amiga Carolina Ferraz, que me ajudou desde o início e por ser uma amiga verdadeira e sempre muito presente. Ao Gustavo Varca, por todo apoio e amizade. Ao Henrique por toda ajuda na conclusão deste trabalho e que nos momento de desespero aparecia com um pequeno gesto para me alegrar.

Aos grandes amigos e funcionários do CTR, Fábio E. Costa, Laercio Carvalho e Yasko Kodama por todo carinho, preocupação e não tenho palavras para expressar o quanto você foi importante para mim. Ao Jorge Ambiel por ter me auxiliado durante os cortes das amostras.

Ao Paulo de Souza Santos e Pablo A. Vasquez Salvador por todo apoio, amizade e irradiação das amostras.

Aos nossos queridos secretários, Claudia Regina Nolla agradeço imensamente todo apoio desde a iniciação e principalmente pela nossa amizade, ao Marcos Cardoso Silva também pelo apoio e sempre estar disposto a ajudar. 
À Dra. Andrea Dórion Rodas pela amizade, conselhos e por todas as dicas na realização do trabalho.

À todos os amigos do Centro de Biotecnologia do IPEN.

Ao Marcelo Veloso por todo apoio e pela parceria que ampliou nossos conhecimentos e a sua orientadora Dra. Denise Maria Zezell.

Aos amigos Luiza Stecher, Clécia Souza e todos que participaram dos nossos almoços divertidos.

As chefias do CTR por terem me acolhido muito bem, Margarida M. Hamada, Leonardo Gondim e Wilson P. Calvo.

Aos professores de inglês, ao grande amigo Ubirajara Nogueira Barbosa pela incansável ajuda nos estudos da língua inglesa e por ser um grande exemplo e a querida Élide Mastena por toda a preparação para o exame de proficiência e por sempre me tratar com muito carinho.

Ao André La Paz pela oportunidade do curso de espanhol que me possibilitou participar de cursos e congressos no exterior.

À CNPq, pela bolsa concedida, ao IPEN pela oportunidade, à Agência Internacional de Energia Atômica por todo apoio, à FAPESP pelo projeto que possibilitou a compra do OCT sensível à polarização.

À Carolina Solis de Plato por toda contribuição nesta jornada, por ser uma excelente profissional e principalmente por me ajudar a seguir em frente e me levantar quando foi necessário.

Aos meus familiares que sempre me incentivaram Samara Sanchez Santin, Giulia Santin, Renzo Santin, Mauricio Bassicheto, Ivone R. Bassicheto, Marina R. Bassicheto, Vitor R. Bassicheto e Salvador Plumeri Jr.

Em especial, aos meu queridos avós, Daunice Pendezza Plumeri e Salvador Plumeri por toda dedicação, pelo infinito carinho e por terem sido o alicerce durante a minha formação.

Em especial, à minha querida e única irmã Daniele P. Santin por sempre acreditar em minha capacidade, ao meu cunhado Luciano Marques por todo carinho e ao meu mais novo e querido sobrinho e afilhado, Miguel S. M. Marques que nesta reta final veio de presente para a titia! 
À família que eu escolhi, Deisi Paschoal de Almeida, Carlos Eduardo de Almeida, Marília Paschoal de Almeida, Danilo Miguel Paschoal de Almeida e Regina Celi Paschoal por todo carinho e conforto.

Aos meus queridos amigos, em especial Luciana Siqueiros, Alvin Vanderley Madureira, Thais Munhoz Hernandez e todos de Arujá que sempre me incentivaram e apoiaram.

À todos os professores que fizeram parte da minha formação, obrigada!

À Deus por minha existência e sabedoria. 
"Não haverá borboletas se a vida não passar por longas e silenciosas metamorfoses."

Rubem ALVES 


\section{Avaliação morfológica e biomecânica dos efeitos da radiação gama em osso humano liofilizado ou congelado}

Stefany Plumeri Santin

\section{RESUMO}

Diversos pacientes são beneficiados com ossos armazenados em Bancos de Tecidos e utilizados em cirurgias reconstrutivas ortopédicas e em implantodologia como aloenxertos. No entanto, há uma intensa preocupação em garantir segurança na esterilidade do aloenxerto para proporcionar eficácia no transplante. Para minimizar possíveis contaminações utiliza-se a radiação ionizante como forma de esterilização final, desde que esta seja feita de maneira controlada, evitando possíveis modificações na matriz óssea. No presente trabalho, utilizamos as técnicas de colorimetria para avaliar modificações estéticas, Tomografia por Coerência Óptica, Tomografia por Coerência Óptica sensível à polarização, espectroscopia Raman e ensaios mecânicos de compressão para identificar as possíveis alterações na matriz óssea, ocasionadas pela forma de preservação, assim como, pelas diferentes doses de irradiação. Foram obtidas 8 amostras de fíbulas de 4 doadores, fracionadas de maneira a obter 48 amostras liofilizadas e 48 amostras congeladas. As amostras foram irradiadas com as doses de 15,25 e 50 kGy comparando os resultados com o controle não irradiado. Observamos uma diminuição na intensidade das cores iniciais, mais relacionada com o processamento e preservação das amostras, e para as amostras irradiadas somente foi observado um aumento da coloração amarelada na dose de $50 \mathrm{kGy}$. A forma de preservação por liofilização ocasionou maiores modificações na estrutura terciária do colágeno dos ossos irradiados nas diferentes doses, principalmente nas doses acima de $25 \mathrm{kGy}$, porém estas modificações não foram suficientes para alterar a organização das fibras de colágeno. Quanto à resistência mecânica, verificou-se que as amostras liofilizadas foram menos resistentes que as congeladas e nas doses de $15 \mathrm{kGy}$ e $25 \mathrm{kGy}$ em ambas as formas de preservação ocorreu uma tendência a diminuir a resistência mecânica em relação ao controle.

Palavras-chave: osso, Banco de Tecidos, esterilização, radiação ionizante. 


\title{
Morphological and biomechanical evaluation of gamma radiation \\ effects on lyophilized or frozen human bone
}

\author{
Stefany Plumeri Santin
}

\begin{abstract}
Several patients are benefited with bones stored in Tissue Banks and used in orthopedic reconstructive surgery and implantodology as allografts. However, there is a strong concern to ensure safety in sterile allograft transplantation in order to provide efficacy. To minimize a probable contamination, ionizing radiation is used as a form of final sterilization, since the procedure is done in a controlled manner, avoiding possible changes in the bone matrix. In this dissertation, the techniques of colorimetry were used to evaluate aesthetic modifications; Optical Coherence Tomography, Optical Coherence Tomography sensitive to polarization, Raman spectroscopy and mechanical compression was carried out to identify possible changes in the bone matrix, caused by the preservation method, as well as the different irradiation doses. Eight fibulae from four donors were fractionated and from that forty-eight lyophilized samples and forty-eight frozen samples were obtained. The samples were irradiated with doses of 15,25 and $50 \mathrm{kGy}$ and the results were compared with the non-irradiated control. A decrease in the intensity of the initial colors was noticed and it was more related to the processing and preservation of the samples; for the irradiated samples, only an increase in the yellowness was observed, in the $50 \mathrm{kGy}$ doses. The lyophilization preservation method caused major changes in the tertiary structure of the bone collagen irradiated at different doses, particularly at doses above $25 \mathrm{kGy}$, but these changes were not enough to change the organization of collagen fibers. Regarding the mechanical strength, were detected that lyophilized samples were less resistant than those which were frozen. With doses of $25 \mathrm{kGy}$ and $15 \mathrm{kGy}$, in both forms of preservation, the mechanical strength tended to decrease, compared to the control. Therefore, it was observed that the aesthetic and structural changes caused by the different irradiation doses depend on the processing used in the Tissue Banks, besides the preservation method selected.
\end{abstract}

Keywords: bone, Tissue Bank, sterilization, ionizing radiation. 


\section{SUMÁRIO}

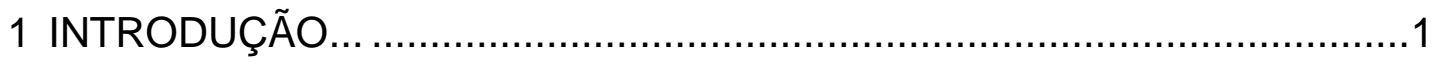

2 OBJETIVOS

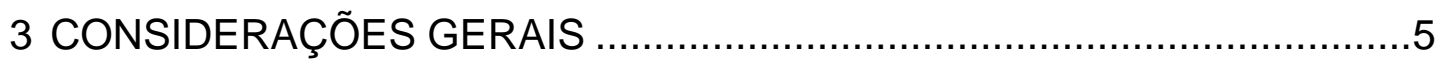

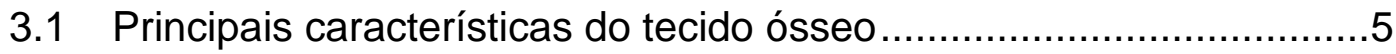

3.2 Colágeno

3.3 Aplicação de tecido ósseo como aloenxerto .....................................

3.4 Introdução aos Bancos de Tecidos ………......................................11

3.5 Preservação de tecidos biológicos ..................................................12

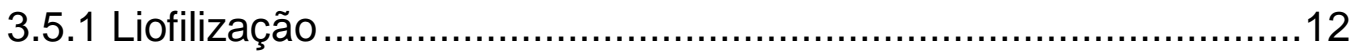

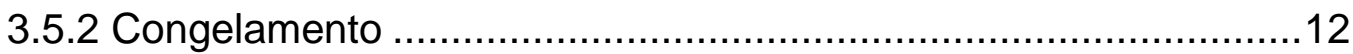

3.6 Esterilização por Radiação lonizante ...............................................13

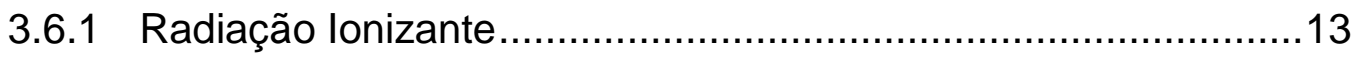

3.6.1.1 Irradiador Multipropósito ……………………………......15

3.6.2 Mecanismos envolvidos na inativação de micro-organismos por radiação ionizante 16

3.6.3 Diferentes doses empregadas na esterilização por radiação ionizante $\quad 17$

3.7 Técnicas utilizadas para avaliação das alterações no tecido ósseo.18

3.7.1 Colorimetria 18

3.7.2 Tomografia por Coerência Óptica …………………................19

3.7.3 Tomografia por Coerência Óptica sensível à polarização ..........22

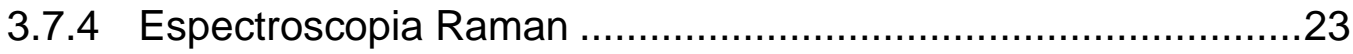

3.7.5 Propriedades Mecânicas .......................................................24

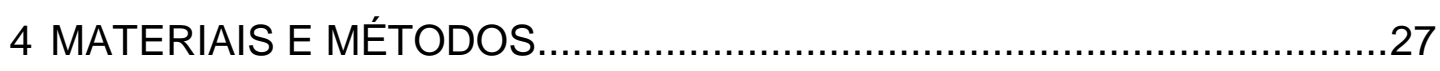

4.1 Aprovação do Comitê de Ética ........................................................27

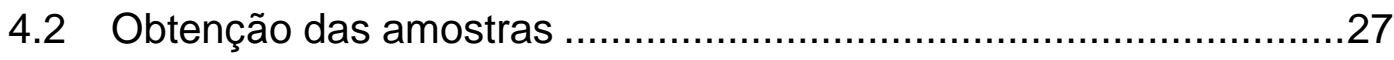


4.3 Processamento das amostras

4.4 Identificação das amostras ............................................28

4.5 Fluxograma de trabalho..................................................28

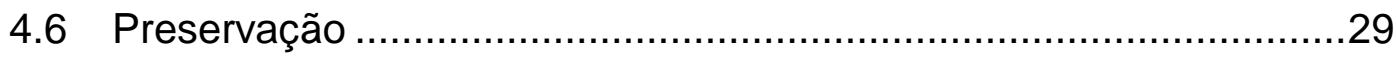

4.6.1 Liofilização................................................................29

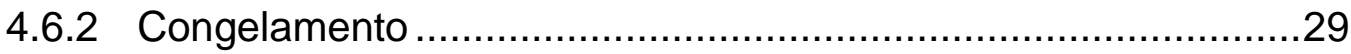

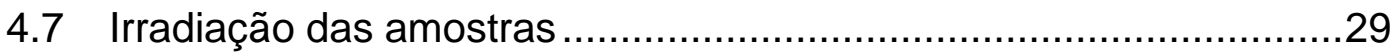

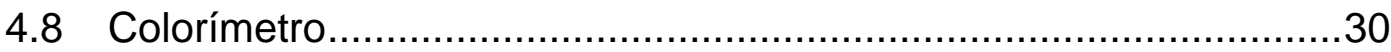

4.9 Tomografia por Coerência Óptica …............................................30

4.10 Cálculo do Coeficiente de Atenuação Óptica Total ......................30

4.11 Tomografia por Coerência Óptica sensível à Polarização .............31

4.12 Espectroscopia Raman ......................................................32

4.13 Ensaio Mecânico de Compressão.........................................32

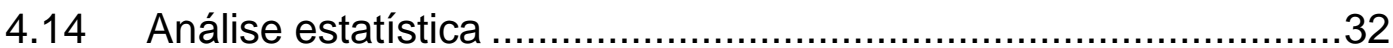

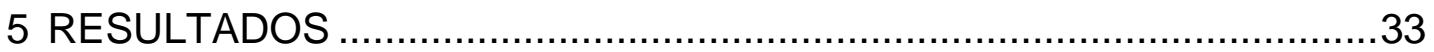

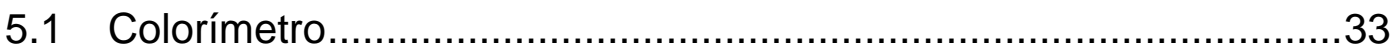

5.2 Tomografia por Coerência Óptica .........................................35

5.3 Tomografia por Coerência Óptica sensível à Polarização .................37

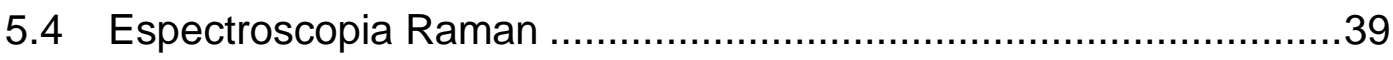

5.5 Ensaio Mecânico de Compressão ........................................41

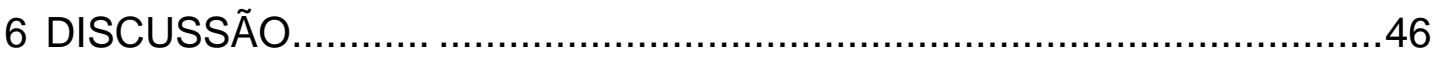

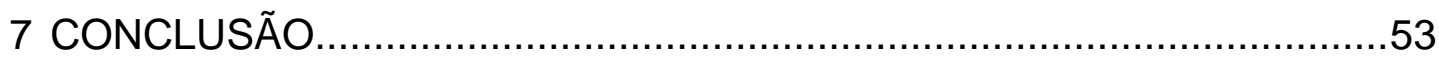

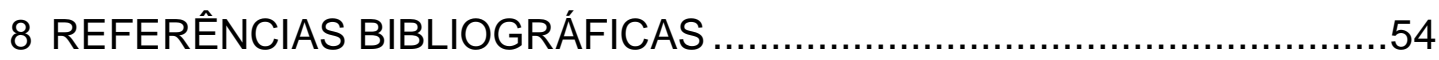

APÊNDICE 1 - Imagens das amostras congeladas obtidas em diferentes posições (1-3) por Tomografia por Coerência Óptica sensível à polarização. 
APÊNDICE 2 - Imagens das amostras liofilizadas obtidas em diferentes posições (1-3) por Tomografia por Coerência Óptica sensível à

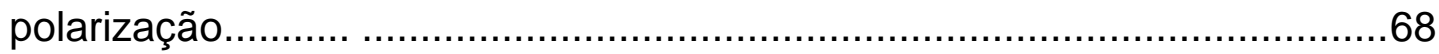

APÊNDICE 3 - Aprovação do Comitê de Ética em Pesquisa ......................74 APÊNDICE 4 - Legislação para utilização de tecidos biológicos em

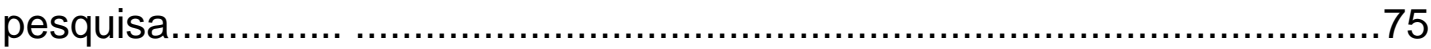




\section{LISTA DE FIGURAS}

FIGURA 1- A. Fotografia de cabeça de fêmur serrada, mostrando as trabéculas do osso esponjoso (Junqueira \& Carneiro, 2004). B. Imagem, da estrutura das trabéculas do tecido ósseo esponjoso humano, obtida pela técnica de Tomografia por Coerência Óptica (foto de autoria própria).

FIGURA 2- Esquema da parede da diáfise dos ossos longos. Observam-se três tipos de tecido ósseo lamelar: os sistemas de Havers e as lamelas circunferenciais externas e as internas. À direita pode-se observar um canal de Havers isolado com a presença de capilar sanguíneo central e muitos osteócitos com seus prolongamentos (Junqueira \& Carneiro, 2004).

FIGURA 3- Molécula de colágeno. A imagem evidencia a formação do colágeno por duas cadeias $\boldsymbol{\alpha} 1$ associadas com uma terceira cadeia, do tipo $\boldsymbol{\alpha} 2$. Cada cadeia alfa e enrolada em alfa hélice com passo a direita e são unidas por pontes de hidrogênio e interações hidrofóbicas. Cada volta completa da hélice percorre uma distância de 8,6 nm (Junqueira \& Carneiro, 2004)

FIGURA 4- Diagrama esquemático que apresenta a organização das fibrilas e fibras de colágeno em associação aos cristais minerais (Rho et al., 1998).

FIGURA 5 - Série de radiações eletromagnéticas e os comprimentos de onda $\lambda$ (em metros) das diferentes radiações eletromagnéticas. Adaptado de Dahlan, 2001 14

FIGURA 6 - Foto do irradiador multipropósito localizado no Centro de Tecnologia das Radiações. 15

FIGURA 7 - Representação dos três eixos da escala CIELab. L*: eixo da luminosidade, variação do mais escuro (0) para o mais claro (100); $\mathbf{a}^{*}$ : eixo da variação de cores de verde (-a) para o vermelho(+a); $\mathbf{b}^{*}$ : eixo da variação do azul (b) para 0 amarelo (+b). http://corisectelmo.blogspot.com.br/2011/01/aula-21espaco-de-cor-lab.html

FIGURA 8 - Região de atuação, resolução e profundidade de penetração das técnicas de OCT, microscopia confocal e ultrassom (Raele, 2009). 20

FIGURA 9 - Esquema básico de um sistema OCT (Freitas et al., 2006) ......21 
FIGURA 10 - Deslocamentos característicos do espectro Raman referente ao tecido ósseo que são representados em unidades de número de onda correspondente à energia vibracional $\left(\mathrm{cm}^{-1}\right)$ (espectro do próprio autor). .23

FIGURA 11- Modelo do direcionamento das diferentes cargas. http://www.gustrength.com/newsletter:tension-compression-shear-torsion. .25

FIGURA 12 - Amostra submetida ao ensaio mecânico de compressão ......25

FIGURA 13 - Gráfico obtido pelo software Bluehill da máquina de ensaios mecânicos universal (Instron). As setas indicam os pontos de resistência máxima e de ruptura.

FIGURA 14 - Fluxograma das etapas de trabalho .28

FIGURA 15 - Análise das amostras nos ângulos de $0^{\circ}$ e $180^{\circ}$ .30

FIGURA 16 - Imagem obtida por Tomografia por Coerência Óptica .30

FIGURA 17 - Interface do programa utilizado para o cálculo do coeficiente de atenuação óptica total.

FIGURA 18 - Padrão de cores utilizado para representar a fase acumulada.

FIGURA 19 - A. Medida do diâmetro interno; B. Medida do diâmetro externo.

FIGURA 20 - A) Parâmetro $a^{*}$ das amostras congeladas e irradiadas nas diferentes doses de 15, 25 e 50 kGy B) Parâmetro a* das amostras liofilizadas e irradiadas nas diferentes doses de 15, 25 e 50 kGy.

FIGURA 21 - A) Parâmetro $b^{*}$ das amostras congeladas não irradiadas e irradiadas nas diferentes doses de 15, 25 e 50 kGy B) Parâmetro b* das amostras liofilizadas não irradiadas e irradiadas nas diferentes doses de 15, 25 e 50 kGy. ..34

FIGURA 22 - A) Parâmetro $L^{*}$ das amostras congeladas não irradiadas e irradiadas nas diferentes doses de 15, 25 e 50 kGy B) Parâmetro L* das amostras liofilizadas não irradiadas e irradiadas nas diferentes doses de 15, 25 e 50 kGy. ..35

FIGURA 24 - Gráfico das médias dos coeficientes de atenuação ópticas das amostras liofilizadas não-irradiadas e irradiadas nas doses de 15, 25 e 50 kGy. (*) indica diferença estatisticamente significativa em relação ao controle $(p<0,05) \ldots . . .36$ 
FIGURA 25 - Gráfico das médias dos coeficientes de atenuação ópticas das amostras congeladas e liofilizadas não-irradiadas $\left(^{*}\right)$. Indica diferença estatisticamente significativa entre os grupos $(p<0,05)$.

FIGURA 26 - Imagem de PS-OCT das amostras de diferentes doadores, (A) congeladas e não irradiadas; (B) liofilizadas e não irradiadas; (1 a 4) diferentes doadores e ( ) "Franjas" evidenciadas pela técnica.

FIGURA 27 - Imagem de PS-OCT das amostras congeladas (A) e liofilizadas (B), irradiadas na dose de 15 kGy (1), 25 kGy (2) e 50 kGy (3).

FIGURA 28 - A) Média da razão mineral/matriz das amostras congeladas não irradiadas e irradiadas nas diferentes doses de 15, 25 e 50 kGy B) Média da razão mineral/matriz das amostras liofilizadas não irradiadas e irradiadas nas diferentes doses de 15, 25 e 50 kGy. $\left({ }^{*}\right)$ Indica diferença estatisticamente significativa entre os grupos $(p<0,05)$.

FIGURA 29 - Gráfico da razão mineral/matriz das amostras liofilizadas nãoirradiadas e congeladas não-irradiadas.

FIGURA 30 - Gráfico da resistência máxima (MPa) das amostra ósseas.( $\square$ ) amostras não irradiadas e congeladas; $(\square)$ amostras não irradiadas e liofilizadas; ( -) amostras congeladas e irradiadas com 15 kGy; (○) amostras liofilizadas e irradiadas com 15 kGy; ( $)$ ) amostras congeladas e irradiadas com 25 kGy; ( $\mathbf{A})$ amostras liofilizadas e irradiadas com $25 \mathrm{kGy}$; ( ) amostras congeladas e irradiadas com 50 kGy; ( ) amostras liofilizadas e irradiadas com 50 kGy. 45 


\section{INTRODUÇÃO}

Diversos pacientes têm sido beneficiados com transplantes de tecidos (ossos, cartilagem, tendões, pele, âmnio e outros) provenientes de instituições denominadas Banco de Tecidos. Essas instituições se responsabilizam pela seleção de doadores multi-orgãos ${ }^{1}$ ou cadavéricos ${ }^{2}$, captação, processamento e distribuição destes tecidos que serão utilizados como aloenxertos ${ }^{3}$ (Amatuzzi et al., 2000; Herson \& Mathor, 2006).

Os aloenxertos são utilizados em cirurgias reconstrutivas e em particular o tecido ósseo é utilizado para reparar defeitos ósseos ocorridos por alguma enfermidade ou injúria (Roos et al., 2000).

No entanto, para estes tecidos serem utilizados é necessário garantir a segurança da esterilidade dos mesmos. A norma de esterilização (ISO11137:2006) recomenda um Nível de Segurança de Esterilidade de $10^{-6}$, ou seja, a probabilidade de encontrar um microrganismo vivo em um milhão.

Seguindo as boas práticas de processamento, todas as etapas envolvidas, desde a seleção do doador até o armazenamento do tecido, tem como prioridade a obtenção de tecidos seguros para transplante. Todo o processamento do tecido deve ser realizado de forma asséptica e uma possível contaminação inicial deve ser reduzida nesta etapa, podendo-se utilizar a radiação ionizante como forma de esterilização final (Dziedzic-Goclawska et al., 2005).

A radiação ionizante confere algumas vantagens quando comparada com outros métodos, como por aquecimento, onde há um aumento da temperatura e óxido de etileno, que deixa resíduos tóxicos no tecido. A esterilização por radiação ionizante propicia que os tecidos sejam esterilizados em sua embalagem final evitando re-contaminação posterior e apenas há um aumento mínimo da temperatura além de não produzir resíduos tóxicos (Herson \& Mathor, 2006).

${ }^{1}$ Doador multi-orgão: Doador por morte encefálica

${ }^{2}$ Doador cadavérico: Doador por morte encefálica e parada cardíaca

${ }^{3}$ Aloenxerto: transplante entre indivíduos de uma mesma espécie, mas geneticamente diferentes 
Este método é vantajoso, porém existem algumas controvérsias em relação à dose a ser utilizada. A principal preocupação dos responsáveis pelos Bancos de Tecidos, do corpo médico transplantador e dos pesquisadores da área é saber se o processo de esterilização por radiação ionizante e a forma de preservação podem danificar o tecido, como por exemplo, acarretar modificações na matriz óssea e consequentemente diminuir a eficácia do transplante (Hammer et al., 1999; Kaminski et al., 2012; Vastel et al., 2004).

Em particular, diversos trabalhos discutem a respeito das doses empregadas na esterilização do tecido ósseo, pois o objetivo em comum é que estas garantam a esterilidade e a integridade do enxerto.

Existem controvérsias em relação à dose utilizada para esterilização de aloenxertos ósseos. O Código de Prática "Esterilização por radiação de tecidos alógenos: Requerimento para validação e controle de rotina" elaborado pela International Atomic Energy Agency (IAEA), descreve os cálculos de doses a partir da carga microbiológica inicial, sendo que este guia foi publicado em 2007, mas sua elaboração terminou em 2004, onde recomenda a dose de 25 kGy como a dose mínima que deve ser utilizada para esterilização, seguindo as normas em vigor naquele momento. No entanto, em diversos trabalhos foi observado que doses mais baixas de irradiação são vantajosas por manterem uma melhor preservação da matriz de colágeno, além de preservar as proteínas morfogenéticas (BMPs) e fatores de crescimento que levam a uma melhor incorporação do enxerto (Nguyen et al., 2011). Na norma ISO 11137, revisada em 2006, a dose mínima para esterilização de tecidos biológicos, partindo de uma carga microbiana inicial zero, é de 15 kGy. Dados encontrados na literatura apontam que há uma tendência geral para minimizar a dose utilizando doses abaixo de 25 kGy (Nguyen et al., 2011; Nguyen et al., 2007).

A integridade do enxerto ósseo depende da porção mineral, do colágeno e da interação de ambos, presentes na matriz óssea. Diversos estudos demonstram que a irradiação pode afetar a estrutura do colágeno, como por exemplo, desorganizando a estrutura de tripla hélice da molécula (Dziedzic-Goclawska et al., 2005; Hammer et al., 1999; Martinho Junior, 2012; Nguyen et al., 2007) 
Algumas técnicas não destrutivas podem ser utilizadas para avaliar as possíveis modificações ocasionadas no tecido ósseo, como a Colorimetria sólida, a Tomografia por Coerência Óptica e a Espectroscopia Raman.

A colorimetria sólida permite avaliar as mudanças de cor ocorridas na amostra após a irradiação e essa técnica foi utilizada para quantificar tais modificações, pois alguns profissionais associam essa mudança estética com alterações na matriz óssea, com a consequente diminuição da resistência mecânica devido às possíveis alterações na organização das fibras de colágeno.

A Tomografia por Coerência Óptica (OCT) é uma tecnologia de imagem tomográfica capaz de produzir de forma não destrutiva imagens transversais e de alta resolução. A técnica utilizada é baseada na emissão de um laser infravermelho centrado na amostra e avalia as propriedades de retro espalhamento e reflexão da luz no tecido a ser estudado (Huang et al., 1991) e foi utilizada para avaliar as possíveis modificações ocasionadas na matriz óssea e na organização das fibras de colágeno, esta última visualizada com o auxílio da Tomografia por Coerência Óptica sensível à polarização (PS-OCT) (Xingde et al., 2005).

A espectroscopia Raman é uma técnica de espectroscopia vibracional utilizada para avaliar o espalhamento da luz em moléculas biológicas e tem sido utilizada para avaliar as alterações na composição óssea ocasionada por fatores como idade, doenças ou lesões (Morris \& Mandair, 2011). Neste trabalho a espectroscopia Raman auxiliou na avaliação das mudanças na relação mineral/matriz presente no tecido ósseo.

Os ensaios destrutivos são essenciais para compreender com mais detalhes as modificações ocorridas no tecido, como o ensaio mecânico de compressão que permite avaliar se após a esterilização ocorreu uma redução significativa nas propriedades plásticas, como a diminuição da resistência à força compressiva.

O conhecimento das possíveis modificações que a radiação ionizante pode provocar nos tecidos, poderá ser útil aos responsáveis dos Bancos de Tecidos na decisão da dose de esterilização a ser aplicada aos mesmos, atreladas à forma de preservação e à sua futura utilização. 


\section{OBJETIVOS}

O objetivo deste trabalho foi verificar se diferentes doses de radioesterilização alteram as características físicas, químicas ou mecânicas do tecido ósseo e se estas são dependentes dos métodos de preservação, por congelamento ou liofilização, utilizados pelos Bancos de Tecidos.

Para identificar estas possíveis alterações foram utilizadas as seguintes técnicas: Colorimetria sólida; Tomografia por Coerência Óptica (OCT); Tomografia por Coerência Óptica (OCT) sensível à polarização; espectroscopia Raman e ensaios mecânicos de compressão. 


\section{CONSIDERAÇÕES GERAIS}

Para entendermos as possíveis modificações que podem ocorrer no tecido ósseo, é importante conhecermos as principais características do tecido em questão, as formas de preservação, sua aplicação clínica e a influência das doses de radiação empregadas na esterilização.

\subsection{Principais características do tecido ósseo}

O tecido ósseo é uma forma especializada de tecido conjuntivo e tem por função proporcionar suporte para as partes moles e proteger órgãos vitais, como os contidos na caixa craniana e torácica e no canal raquidiano. Este tecido também aloja e protege a medula óssea, proporciona apoio aos músculos esqueléticos e constitui um sistema de alavancas que amplia as forças geradas na contração muscular (Junqueira \& Carneiro, 2004; Nordin \& Frankel, 2001).

Como os outros tecidos conjuntivos, o tecido ósseo é formado por células e uma matriz extracelular calcificada (matriz óssea). Porém, diferente de outros tecidos conjuntivos, o tecido ósseo apresenta alto teor de matéria inorgânica, na forma de sais minerais, combinado intimamente com uma matriz orgânica (Kierszenbaum \& Tres, 2012; Nordin \& Frankel, 2001).

Entre os componentes da matriz óssea, o principal componente é o colágeno tipo I e, em menor quantidade, o colágeno do tipo $\mathrm{V}$. Os colágenos correspondem a $90 \%$ do peso total da matriz óssea, sendo que dos tipos III, XI e XII são encontrados em quantidades residuais nesta matriz (Ross \& Pawlina, 2008).

O tecido ósseo, exceto superfícies articulares e nos locais de inserção de tendões e ligamentos, é envolto pelo periósteo, uma camada de tecido conjuntivo especializado. O endósteo, outra camada de tecido conjuntivo, reveste a cavidade medular da diáfise e os espaços no interior do tecido ósseo esponjoso (Junqueira \& Carneiro, 2004).

O tecido ósseo pode ser classificado como esponjoso ou compacto. O tecido ósseo esponjoso é formado por uma trama de espículas ou trabéculas ósseas (FIG.1) que delimitam espaços ocupados pela medula óssea, diferente do tecido 
ósseo compacto que aparece como uma massa sólida e não apresenta cavidades visíveis macroscopicamente (Junqueira \& Carneiro, 2004).

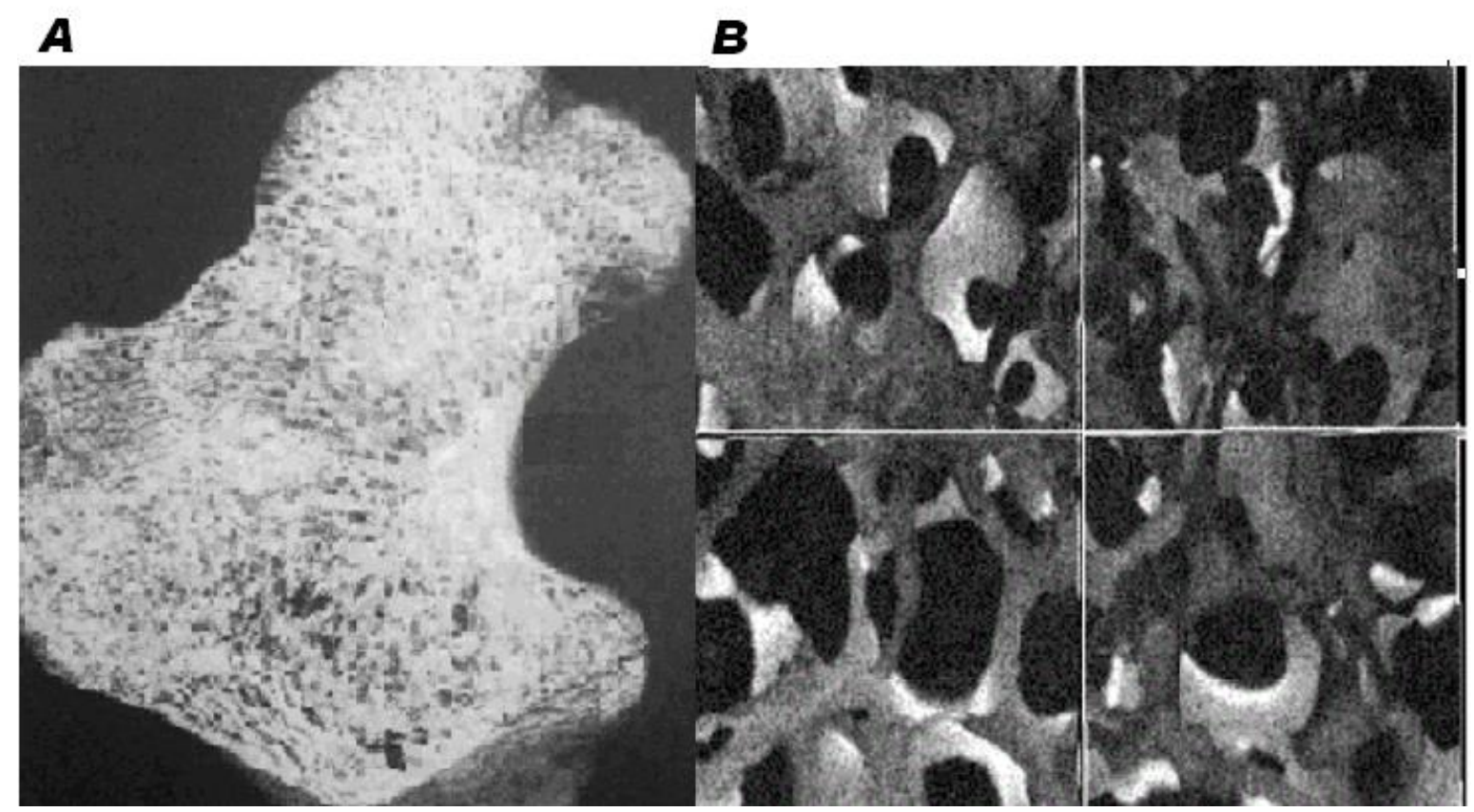

FIGURA 1- A. Fotografia de cabeça de fêmur serrada, mostrando as trabéculas do osso esponjoso (Junqueira \& Carneiro, 2004). B. Imagem, da estrutura das trabéculas do tecido ósseo esponjoso humano, obtida pela técnica de Tomografia por Coerência Óptica (foto de autoria própria).

Nos ossos longos, como a fíbula, as extremidades ou epífises são formadas por osso esponjoso com uma delgada camada superficial compacta. A parte cilíndrica, denominada diáfise, é formada predominantemente por tecido ósseo compacto, apresentando uma pequena quantidade de osso esponjoso na sua parte profunda, delimitando o canal medular (Junqueira \& Carneiro, 2004).

Existem dois tipos de estrutura microscópica de ossos: o osso lamelar e o osso não lamelar. O osso lamelar consiste em um alinhamento regular das fibras colágenas, sendo mecanicamente forte. O osso não lamelar está presente durante o desenvolvimento e as fibras colágenas não estão alinhadas regularmente (Kierszenbaum \& Tres, 2012).

O osso lamelar (FIG. 2) é estruturado em lamelas, as quais são constituídas pela matriz óssea e osteócitos, que ocupam uma cavidade ou lacuna com canalículos radiais e ramificados que adentram nas lamelas das lacunas 
adjacentes (Kierszenbaum \& Tres, 2012). O osso lamelar apresenta quatro padrões distintos:

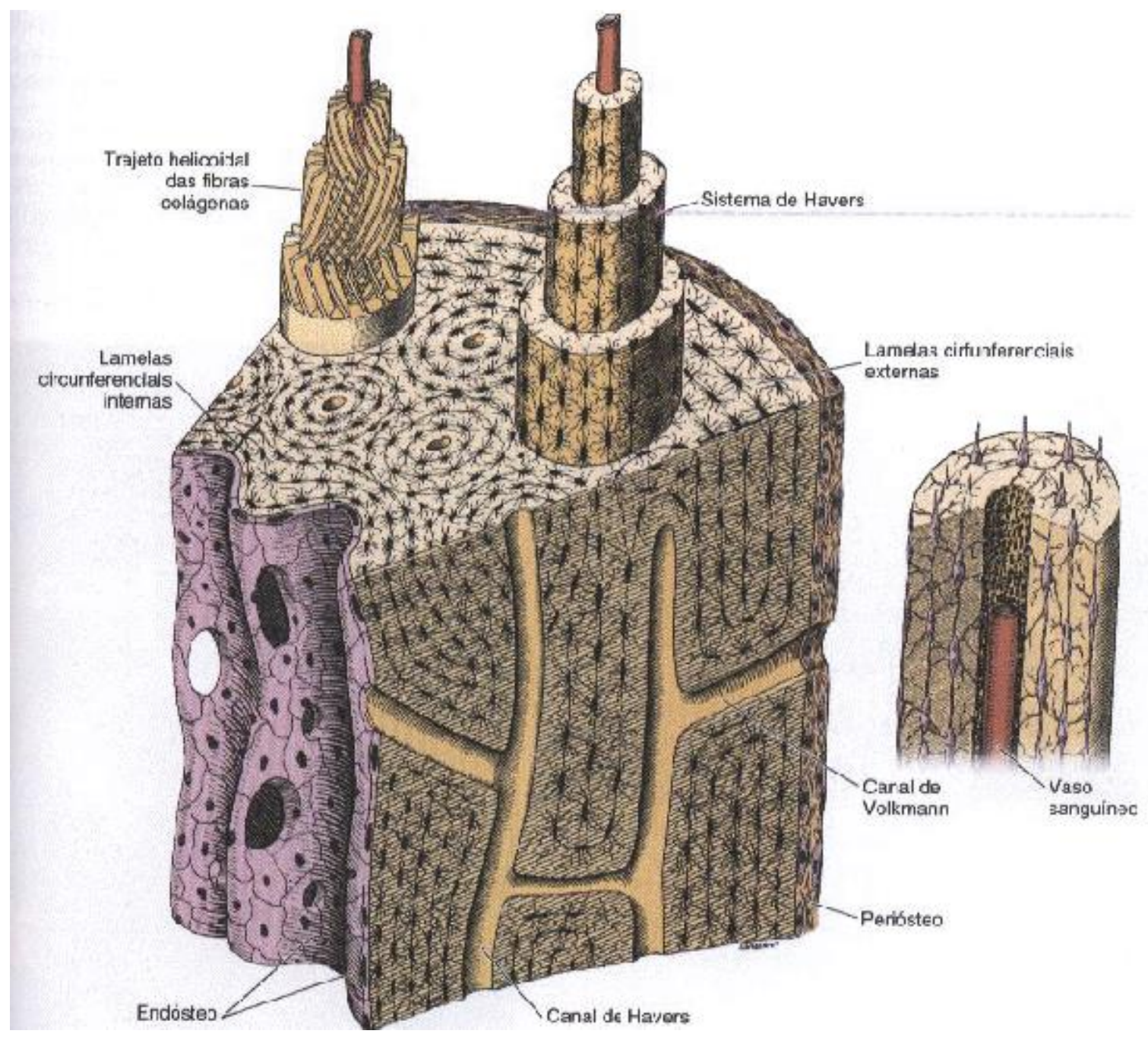

FIGURA 2- Esquema da parede da diáfise dos ossos longos. Observam-se três tipos de tecido ósseo lamelar: os sistemas de Havers e as lamelas circunferenciais externas e as internas. À direita pode-se observar um canal de Havers isolado com a presença de capilar sanguíneo central e muitos osteócitos com seus prolongamentos (Junqueira \& Carneiro, 2004).

> Osteons ou sistemas Haversianos: São formados por lamelas arranjadas concentricamente ao entorno de um canal vascular longitudional.

$>$ Lamelas intersticiais: Localizadas entre os osteons e separadas por uma fina camada conhecida como linha cimentante.

Lamelas circunferênciais externas: Localizadas abaixo do periósteo e são visualizadas na superfície externa do osso compacto. 
Lamelas circunferenciais internas: Dispostas na superfície interna subjacente ao endósteo.

Como visto anteriormente, tanto a matriz orgânica quanto a inorgânica desempenham um importante papel no tecido ósseo e, segundo Viguet-Carrin et al. (2006), a presença de uma matriz mineralizada confere rigidez ao tecido ósseo e as fibras colágenas proporcionam ductilidade e dureza, conferindo a este tecido uma importante resistência a impactos mecânicos. Diversos estudos demonstram que a qualidade da matriz colagenosa é essencial para manter a integridade do tecido ósseo, no próximo tópico adentramos nas características principais desta importante proteína.

\subsection{Colágeno}

Existem 27 tipos distintos de colágeno presentes em tecidos animais e os principais são o tipo I (presente no tecido ósseo), II, III, V e XI que estão dispostos em fibrilas e são encontrados em tecidos que são submetidos as forças de tração, cisalhamento, ou forças de compressão, incluindo tendão, osso, cartilagem e pele (Viguet-Carrin et al., 2006).

A característica predominante desta proteína é ser longa, rígida e apresentar uma estrutura em tripla hélice, ou seja, as três cadeias polipeptídicas de colágeno se torcem umas sobre as outras como uma corda helicoidal (conforme FIG.3) (Alberts et al., 2002). O colágeno tipo I é a principal proteína dos ossos e confere as principais propriedades físicas do tecido.

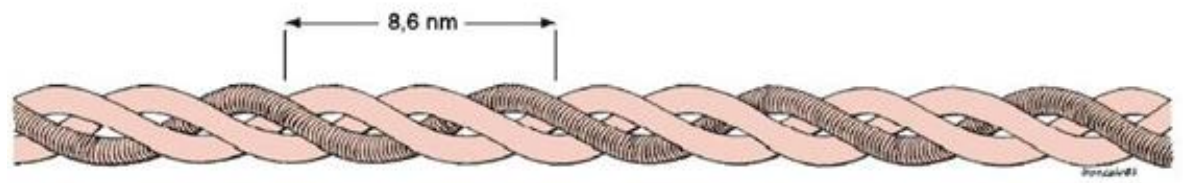

FIGURA 3- Molécula de colágeno. A imagem evidencia a formação do colágeno por duas cadeias $\boldsymbol{\alpha} 1$ associadas com uma terceira cadeia, do tipo $\boldsymbol{\alpha} 2$. Cada cadeia alfa e enrolada em alfa hélice com passo a direita e são unidas por pontes de hidrogênio e interações hidrofóbicas. Cada volta completa da hélice percorre uma distância de 8,6 nm (Junqueira \& Carneiro, 2004).

A configuração tripla hélice do colágeno ocorre devido à sequência repetitiva dos aminoácidos Glicina - X- Y, onde X pode ser qualquer outro aminoácido, mas 
geralmente é uma prolina e $\mathrm{Y}$ é frequentemente uma hidroxiprolina (Rest \& Garrone, 1991).

Essas moléculas (FIG.3) se mantêm agrupadas em polímeros ordenados, denominados fibrilas de colágeno, essas apresentam uma estrutura de cabos finos que possuem de 10-300 nm de diâmetro e muitos micrômetros de comprimento. As fibrilas de colágeno podem ser agrupadas em fibras de colágeno que exibem um formato ainda mais grosso (conforme FIG. 4). Existem outras moléculas de colágenos que ligam as fibrilas umas às outras e a outros constituintes da matriz extracelular (Alberts et al., 2002).

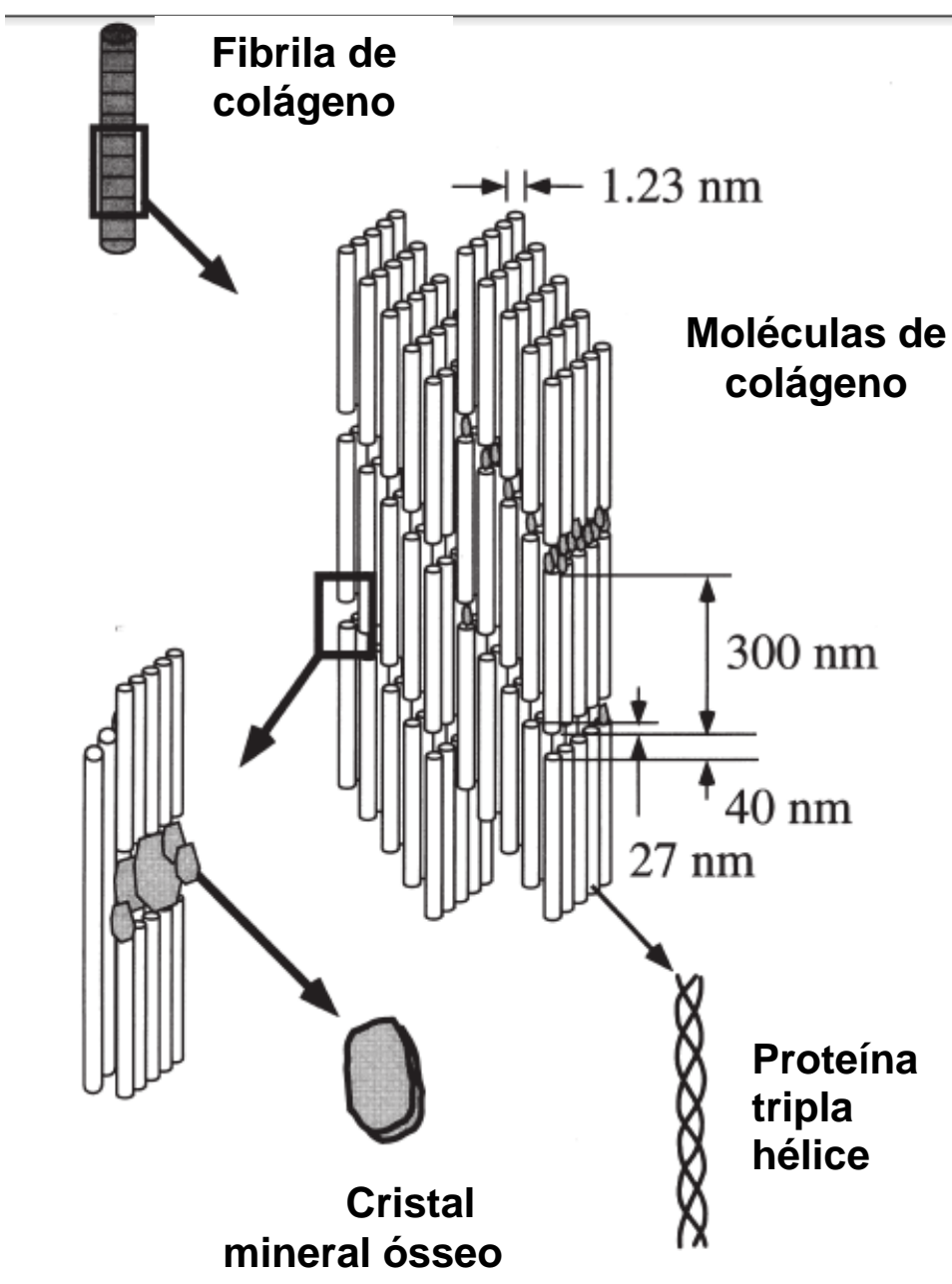

FIGURA 4- Diagrama esquemático que apresenta a organização das fibrilas e fibras de colágeno em associação aos cristais minerais (Rho et al., 1998).

\subsection{Aplicação de tecido ósseo como aloenxerto}

O transplante de um tecido removido de uma área do esqueleto e transferido para outra área no mesmo indivíduo é denominado de autoenxerto (semelhante ao 
termo autólogo). O termo aloenxerto define o transplante entre indivíduos geneticamente diferentes, porém de uma mesma espécie (semelhante ao termo homólogo). O termo xenoenxerto corresponde ao tecido transplantado entre indivíduos de espécies diferentes (semelhante ao termo heterólogo) (Levandowski Jr., et al., 2008).

O enxerto autógeno é vantajoso por diminuir a rejeição e ter as propriedades biológicas do indivíduo, no entanto a desvantagem é que este tipo de aloenxerto requer um segundo local cirúrgico no paciente e para àqueles que tiveram uma perda extensa da região do tecido ósseo, esta opção se torna inviável (Baptista, 2003) e uma alternativa é recorrer ao xenoenxerto ou ao aloenxerto.

O xenoenxerto possui uma desvantagem, pois apresenta propriedades imunológicas distintas, já que pertencem a outra espécie e também há a possibilidade de ocorrer transmissão de doenças pertencentes à espécie (Santos \& Rahal, 2004). A vantagem é que há uma fácil aquisição e alta disponibilidade.

O enxerto alógeno é uma opção para suprir o material do próprio paciente, evitando a necessidade de um segundo local cirúrgico diminuindo o tempo cirúrgico, reduz anestesia e perda sanguínea (Feofiloff \& Garcia, 1996). No entanto, os aloenxertos devem ser selecionados quanto à sua qualidade, saúde óssea e histórico do paciente.

Os enxertos ósseos alógenos são utilizados em procedimentos ortopédicos para reparar defeitos ocasionados por fraturas e reconstrução de regiões extensas de tecido ósseo que foram destruídas por lesões ou por alguma enfermidade (Dziedzic-Goclawska, 2000).

$\mathrm{Na}$ área de implantologia, o enxerto ósseo alógeno tem sido uma ferramenta para pacientes com perda significativa da arquitetura do rebordo alveolar por consequência de uma periodontite, exodontias ou mesmo traumatismos. Esses enxertos alógenos são utilizados para aumento dos rebordos ósseos maxilares que serão receptores dos implantes dentários, restabelecendo altura e espessura óssea para as regiões edêntulas (Del Valle et al., 2006).

As instituições que se responsabilizam pelo processamento e armazenamentos destes tecidos que serão utilizados como aloenxertos são denominadas Banco de Tecidos. 


\subsection{Introdução aos Bancos de Tecidos}

Os Bancos de Tecidos são instituições que se responsabilizam pela seleção de doadores, captação, processamento, esterilização, armazenamento e distribuição de tecidos utilizados em cirurgias reconstrutivas que necessitam de aloenxertos (Vangsness Jr et al., 2003).

Existem bancos que armazenam um único tipo de tecido, como por exemplo, os bancos de ossos ou os bancos de pele, e também há bancos multitecidos que possuem infraestrutura e pessoal treinado para armazenar diversos tecidos como ossos, tendões, córneas, peles e âmnios (Vangsness Jr. et al., 2003).

No Brasil, é obrigatório que essas instituições estejam localizadas em hospitais ou em hemocentros e o Sistema Nacional de Transplantes (SNT) e a Agência Nacional de Vigilância Sanitária (ANVISA) se responsabilizam pelo credenciamento e pela fiscalização dos bancos de tecidos, respectivamente, de acordo com as leis:

- Lei n 9. 434 de fevereiro de 1997, "Dispõe sobre a remoção de órgãos, tecidos e partes do corpo humano para fins de transplante e tratamento e da outras providencias" (Brasil, Lei n 9.434, 1997).

- Lei no 10.211 de 23 de marco de 2001 que "Altera dispositivos da Lei no 9.434, de 4 de fevereiro de 1997, que "dispõe sobre a remoção de órgãos, tecidos e partes do corpo humano para fins de transplante e tratamento" (Brasil, Lei $n^{\circ}$ 10.211, 2001).

- Portaria $n^{\circ} 2.600$ de 21 de outro de 2009, que "Aprova o Regulamento Técnico do Sistema Nacional de Transplantes” (Brasil, Portaria $n^{\circ} 2.600,2009$ ).

Existem alguns critérios para a seleção de doadores a fim de evitar transmissão de doenças ou insucesso do enxerto como, por exemplo, não apresentar histórico de infecção e também não estar acometido de doença crônica ou infectocontagiosa, ausência de febre durante o período de internação e não ter apresentado uso crônico de esteroides. Amostras de sangue são retiradas do paciente para a realização de exames (Ross et al., 2000).

O processamento dos tecidos tem por finalidade efetuar a limpeza para eliminar todas as partes moles, inserções musculares e periósteo (Ross et al., 2000). Todas as etapas do processamento são feitas de forma asséptica e são 
coletadas amostras do tecido que serão submetidas aos meios de cultura para micro-organismos aeróbios, anaeróbios e fungos. Também são realizados testes sorológicos para seleção doadores viáveis, detectando-se os casos de doenças infectocontagiosas ativas e também a cicatriz imunológica (Amatuzzi et al., 2000).

\subsection{Preservação de tecidos biológicos}

Os métodos utilizados para preservação dos tecidos variam de acordo com o tipo de tecido e com o propósito de seu uso. O fator principal da preservação de tecidos biológicos é que o mesmo conserve as propriedades biológicas e mecânicas pertinentes à sua função. As temperaturas de armazenamento devem ser registradas e os materiais de embalagem devem ser adequados para o tipo de armazenagem realizado (Willemer, 1997).

Existem, descritos na literatura, alguns métodos de preservação de tecidos biológicos como congelamento, conservação em glicerol em altas concentrações e liofilização e entre outros (Macedo et al., 1999; Friedlander, 1982). Para o tecido ósseo são utilizados principalmente dois métodos de preservação:

\subsubsection{Liofilização}

A liofilização é uma forma de processamento de tecido ósseo que viabiliza a utilização desses por promover uma intensa diminuição da antigenicidade dos tecidos, sendo capaz de fornecer material biocompatível, mínima alteração bioquímica e durabilidade, além de permitir o seu armazenamento à temperatura ambiente (Macedo et al., 1999; Willemer, 1997)

Uma desvantagem da liofilização pode ser a possível diminuição das propriedades biomecânicas do tecido. Além de cuidados especiais no manuseio do equipamento e necessidade de um protocolo específico para a liofilização de cada tipo e formato de tecido (Willemer, 1997).

\subsubsection{Congelamento}

O congelamento a $-70{ }^{\circ} \mathrm{C}$ é uma das formas de preservação utilizada pelos bancos de tecidos, pois durante esse procedimento o sistema tende a buscar um estado de potencial químico baixo e uma entropia alta. Uma das vantagens da técnica de congelamento é sua praticidade, pois requer poucos recursos físicos 
(somente um freezer de ultra congelamento a $-70{ }^{\circ} \mathrm{C}$ ) e também possibilita a preservação dos tecidos biológicos por longo período (Macedo et al.,1999).

Além dos diferentes tipos de preservação, os Bancos de Tecidos possuem uma enorme preocupação em relação à transmissão de doenças e alguns bancos consideram essencial a utilização da radiação ionizante que proporciona uma forma segura e eficaz para esterilizar tecidos utilizados como aloenxertos.

\subsection{Esterilização por Radiação lonizante}

Atualmente cresce o interesse dos Bancos de Tecidos em esterilizar tecidos biológicos que serão utilizados como aloenxertos, para isso, um método eficaz e que já está sendo utilizado no Brasil é a esterilização por radiação ionizante. A radiação ionizante causa uma moderada, mas controlável, elevação da temperatura conferindo uma vantagem quando comparada aos outros métodos, pois materiais sensíveis à temperatura podem ser radioesterilizados e também materiais congelados podem ser irradiados mantendo suas condições de armazenagem. Outra vantagem do processo é a possibilidade dos materiais serem esterilizados em sua embalagem final descartando os riscos de uma recontaminação (Dziedzic-Goclawska et al., 2005).

\subsubsection{Radiação lonizante}

A radiação ionizante é um tipo de radiação que possui energia suficiente para retirar elétrons de átomos e moléculas e converter em partículas eletricamente carregadas, denominadas íons. Essas reações dão origem a radicais livres que usualmente podem ser altamente reativos levando a modificações químicas na matéria (Dahlan, 2001; Drobny, 2013).

As partículas de alta energia e a radiação eletromagnética são dois tipos de radiação ionizante. As partículas de alta energia podem ser carregadas negativamente ou positivamente e são geradas por máquinas ou podem ser geradas por radioisótopos, como as partículas beta $(\beta)$ e alfa $(\alpha)$. As partículas alfa $(\alpha)$ apresentam um baixo poder de penetração na matéria e podem penetrar alguns microns nos tecidos biológicos. Já as partículas beta $(\beta)$ são moderadamente penetrantes e podem penetrar alguns milímetros nos tecidos biológicos (Dahlan, 2001). 
A radiação eletromagnética compreende ondas de rádio, microondas, luz visível, ultravioleta, raios-X e raios gama (conforme FIG. 5)

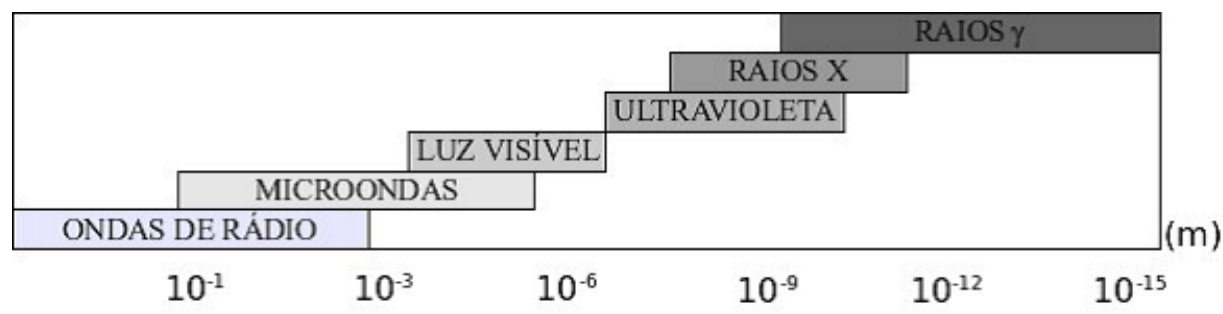

FIGURA 5 - Série de radiações eletromagnéticas e os comprimentos de onda $\lambda$ (em metros) das diferentes radiações eletromagnéticas. Adaptado de Dahlan, 2001.

Os raios $\mathrm{X}$ e os raios gama $(\gamma)$ possuem um comprimento de onda curto $\mathrm{e}$ energias superiores a $50 \mathrm{eV}$, sendo assim são capazes de ionizar átomos e moléculas. Essas alterações geram efeitos e alteram algumas propriedades nos materiais que foram submetidos a este tipo de radiação. A geração dos raios $X e$ dos raios gama é distinta, sendo que os raios $X$ são gerados por máquinas e os raios gama são emitidos por radioisótopos (Dahlan, 2001; Drobny, 2013).

Os radioisótopos (também conhecidos como isótopos radioativos ou radionuclídeos) ocorrem naturalmente ou podem ser produzidos artificialmente em um reator nuclear. Os radioisótopos consistem em elementos instáveis que possuem excesso de nêutrons ou prótons e emitem radiação ( $\alpha, \beta$ e y) à medida que se desintegram espontaneamente ou decaem para um estado estável (QUADRO 1) (Dahlan, 2001).

QUADRO 1 - Meia-vida e energia de radiação dos isotopos ${ }^{60}$ Co e ${ }^{137} \mathrm{Cs}$.

\begin{tabular}{|lccc|}
\hline Fonte & Meia-vida (anos) & Tipo de radiação & Energia (Mev) \\
\hline${ }^{{ }^{60} \text { Co }}$ & $\beta$ & 0,341 \\
& 5,27 & V & 1,332 \\
& & $Y$ & 1,173 \\
${ }^{137}$ Cs & 30 & $\beta$ & 0,520 \\
& & $Y$ & 0,662 \\
\hline
\end{tabular}

fonte: Dahlan, 2001. 


\subsubsection{Irradiador Multipropósito}

O irradiador Multipropósito do IPEN-CNEN/SP (FIG. 6), localizado no Centro de Tecnologia das Radiações foi desenvolvido e projetado com tecnologia nacional.

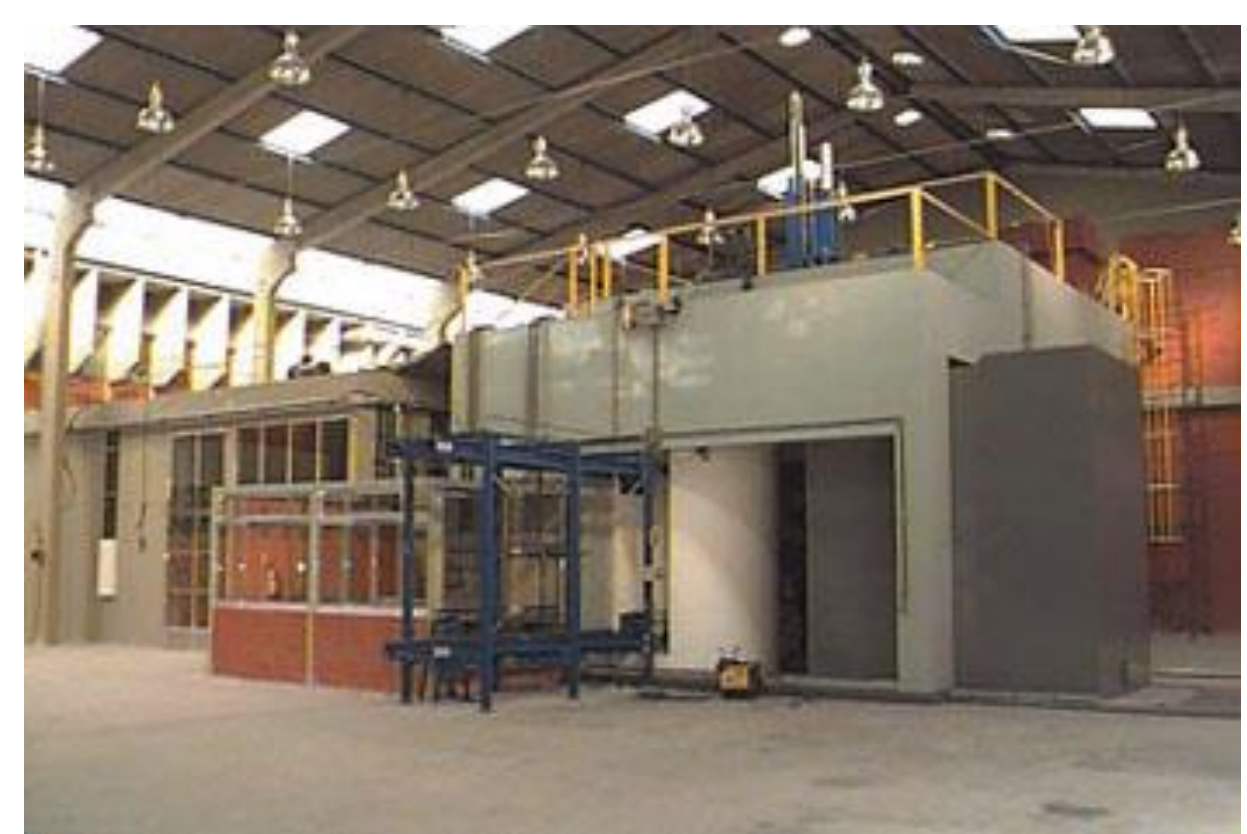

FIGURA 6 - Foto do irradiador multipropósito localizado no Centro de Tecnologia das Radiações.

O sistema possui fontes radioativas de colbalto-60 que ficam submersas em uma piscina contendo água desmineralizada, que atua como uma blindagem para as radiações. A máquina possui sistemas específicos de blindagem e também foram desenvolvidos sistemas de segurança, até mesmo a prova de abalos sísmicos (IPEN, 2004).

O irradiador possui uma piscina de $7,0 \mathrm{~m}$ de profundidade e $2,7 \mathrm{~m}$ de diâmetro e duas portas de concreto. Sendo que uma das portas é deslizante para montagem e manutenção da instalação (4,0 metros de comprimento, por 4,0 metros de altura e 2,45 metros de largura) e a outra é uma porta giratória para entrada e saída de produtos (2,65 metros de diâmetro, por 4,0 metros de altura) e possui paredes de concreto com 1,80 metros de espessura (Calvo, 2005). 


\subsubsection{Mecanismos envolvidos na inativação de micro-organismos por radiação ionizante}

A radiação ionizante pode interagir diretamente no DNA dos microorganismos e levar a alterações estruturais, como as quebras simples ou duplas da dupla cadeia do DNA (dano direto). Outra forma de induzir alterações é por meio do dano indireto, onde ocorre a radiólise da água e a produção de radicais hidroxilas $(\bullet \mathrm{OH})$ altamente reativos e na presença de oxigênio o dano é potencializado, pois há uma interação do oxigênio com o peróxido ocorrendo um aumento nas modificações da cadeia do DNA (Dziedzic-Goclawska et al., 2005).

A inativação de micro-organismos segue uma função exponencial negativa, inversamente proporcional à probabilidade de sobrevivência do micro-organismo em questão, portanto é de extrema importância conhecer qual microrganismo e a quantidade de vivos (carga microbiana) no tecido antes da esterilização por radiação, sendo este um fator fundamental para a eficiência do processo. Sendo assim, a seleção da dose a ser aplicada durante o procedimento depende de três fatores como a carga microbiana, a resistência dos micro-organismos presentes e do Nível de Segurança de Esterilidade (NSE) (Dziedzic-Goclawska et al., 2005).

O Nível de Segurança de Esterilidade corresponde à probabilidade de encontrar um micro-organismo viável no tecido biológico após ser irradiado a uma determinada dose. De acordo com a norma ISO 11.137:2006 ("Esterilização de produtos para o cuidado da saúde"), o NSE é de $10^{-6}$, ou seja, a probabilidade de encontrar 1 micro-organismo viável em 1.000.000, após a esterilização.

A utilização da radiação ionizante para esterilização é incentivada pela Agência Internacional de Energia Atômica (AIEA), sendo responsável pela publicação de guias para execução com qualidade deste procedimento. Atualmente estes guias estão sendo atualizados segundo as novas versões das normas ISO.

A instituição brasileira envolvida na atualização dos guias e utilização dos mesmos para atender os Bancos de Tecidos no procedimento de esterilização por radiação ionizante é Instituto de Pesquisas Energéticas e Nucleares (IPENCNEN/SP), esta instituição é também responsável por proporcionar treinamentos e pesquisas para um melhor domínio da técnica, além de disseminar os cuidados específicos para este tipo de irradiação, para as plantas irradiadoras que queiram oferecer este serviço. 


\subsubsection{Diferentes doses empregadas na esterilização por radiação ionizante}

A esterilização por radiação ionizante depende da quantidade de energia transferida, do número de micro-organismos presentes e da resistência dos microorganismos frente ao método de esterilização, definido pelo termo $D_{10}$ (DziedzicGoclawska et al., 2005). O termo $D_{10}$, comumente expresso em kGy, é a dose de radiação necessária para reduzir a população microbiana inicial de um $\log _{10}$, ou seja, reduzi-la em $90 \%$.

A dose de 15 kGy, conforme a norma ISO 11137:2006, é a dose mínima para esterilização de tecidos biológicos, partindo de uma carga microbiana inicial zero.

A Agência Internacional de Energia Atômica recomenda a dose de 25 kGy, embora alguns autores acreditem que esta dose é insuficiente para eliminar os micro-organismos de tecidos biológicos e recomendam doses $\geq 30 \mathrm{kGy}$, satisfatórias para a inativação do vírus, pois a dose de 25 kGy não é o suficiente para esterilizar tecidos que estejam contaminados com HIV (Fideler et al., 1994), ou outras contaminações virais. Enquanto que Conway \& Tomford (1992) demonstrou que somente doses $\geq 50 \mathrm{kGy}$ são suficientes para inativação do vírus do HVI.

Diversos estudos se concentram nos possíveis danos teciduais que podem ocorrer durante a radioesterilização. Dziedzic-Goclawska et al., 2005 demonstrou que no estado seco (liofilizado), pelo efeito direto da radiação, ocorre prioritariamente a ruptura da cadeia polipeptídica do colágeno e no estado úmido, pela radiólise da água (efeito indireto), pode ocorrer o cruzamento intra e intermolecular das cadeias de colágeno.

Uma das formas de avaliar a modificação nas cadeias de colágeno e na matriz óssea é por ensaios mecânicos. Em 1975, Triantafyllou et al., realizou ensaios de tensão e com os dados obtidos evidenciou que a resistência a flexão do osso reduziu de 10 a $30 \%$ em relação ao controle, para ossos liofilizados e esterilizados com uma dose de 30 kGy. Em 1976, Komender et al., demonstrou que $90 \%$ da resistência a torsão não foi alterada até a dose de $30 \mathrm{kGy}$, o mesmo não foi observado para as doses maiores (até $60 \mathrm{kGy}$ ), onde houve uma redução na resistência às propriedades de torsão, compressão e flexão. 
Estudos recentes, como o realizado por Kaminski et al., 2012, avaliou por ensaio mecânico de compressão as diferentes formas de processamento (osso não-desengordurado e osso desengordurado), o efeito da radioesterilização utilizando doses de 25 e $35 \mathrm{kGy}$ em ossos congelados e em temperatura ambiente. Este autor constatou que o limite de elasticidade e resistência foram aumentados significativamente na dose de $25 \mathrm{kGy}$, mas o mesmo não foi visto para a dose de $35 \mathrm{kGy}$. Além disso, a radiação em temperatura ambiente diminuiu a resistência à carga máxima, limite de elasticidade, resistência e tensão máxima.

A rigidez e a resistência estão associadas com a fase mineral do tecido ósseo e a tensão está associada à matriz do colágeno (Zioupos \& Currey, 1998). A fase mineral do tecido ósseo é relativamente invulnerável à radiação ionizante, no entanto as alterações na resistência mecânica estão associadas com as modificações nas cadeias de colágeno e sua interação com a fase mineral (Wright et al., 1981).

Além dos ensaios mecânicos, outras técnicas podem ser utilizadas para avaliar as possíveis alterações acarretadas no tecido ósseo após a radioesterlização, como a colorimetria para avaliar mudanças estéticas, a Tomografia por Coerência Óptica, a Tomografia por Coerência Óptica sensível à polarização e a Espectroscopia Raman. Essas técnicas serão descritas brevemente no próximo tópico.

\subsection{Técnicas utilizadas para avaliação das alterações no tecido ósseo}

\subsubsection{Colorimetria}

A colorimetria é a ciência e a tecnologia que emprega modelos matemáticos para quantificar e descrever as percepções humanas da cor, a qual é considerada um processo psico-visual. As características da cor são definidas por três eixos: o eixo da luminosidade e dois atributos da cromaticidade, que são representados pelas siglas $L^{*}$, $a^{*}$ e $b^{*}$ obtidos da escala CIELAB ou CIE L*a*b* da (apud Souza et al., 2008).

A cromaticidade é representada pela raiz quadrada da soma dos valores de $a^{*}, b^{*}$ e $L^{*}$. No eixo $a^{*}$, quanto mais positivo, refere-se ao aumento da cor vermelha e quanto mais negativo, refere-se ao aumento da coloração verde. Igualmente no eixo $b^{*}$, quanto mais positivo, refere-se ao aumento da cor amarela e quanto mais 
negativo refere-se ao aumento da coloração azul (FIG. 7). O eixo $L^{*}$ corresponde à luminosidade e varia de preto (0) a branco (100) (Souza et al., 2008).

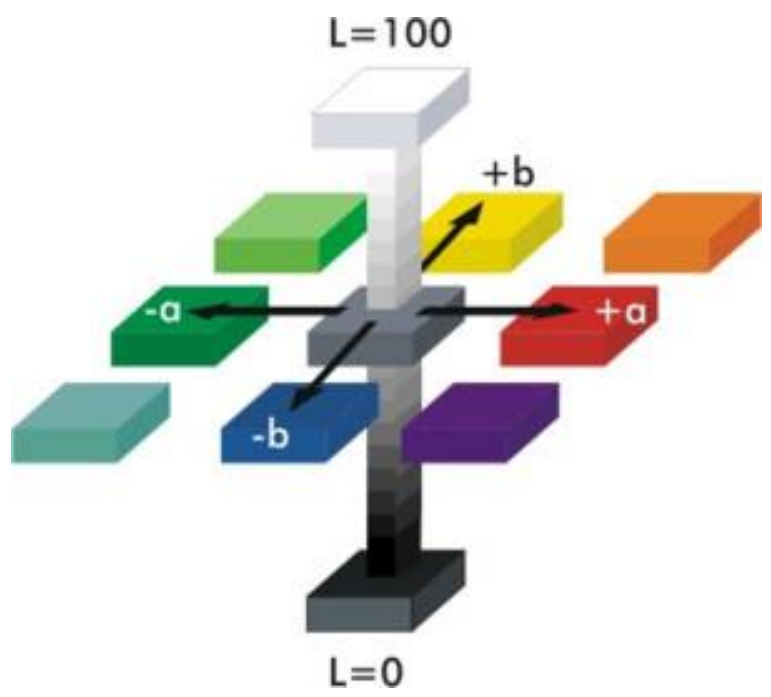

FIGURA 7 - Representação dos três eixos da escala CIELab. L*: eixo da luminosidade, variação do mais escuro (0) para o mais claro (100); $\mathbf{a}^{*}$ : eixo da variação de cores de verde (-a) para o vermelho(+a); $\mathbf{b}^{*}$ : eixo da variação do azul (-b) para o amarelo (+b). http://corisectelmo.blogspot.com.br/2011/01/aula-21-espaco-de-cor-lab.html

Em 2010, Reichert utilizou a colorimetria para ponderar os diferentes clareamentos dentais e constatar o melhor procedimento. Em 2012, Soares utilizou a técnica para avaliar a modificação de cor em membrana amniótica após o processamento por radiação ionizante e a mesma foi sensível para detectar tais alterações.

Na literatura, não existem trabalhos que utilizam a colorimetria para avaliar as modificações de cor em ossos que serão utilizados em transplantes.

\subsubsection{Tomografia por Coerência Óptica}

Em 1991, Huang et al., demonstrou que a Tomografia por Coerência Óptica (do inglês Optical Coherence Tomography - OCT) pode ser utilizada para se obter imagem transversais de tecidos biológicos. Esta técnica se baseia na emissão de um raio laser de baixa coerência e de pulsos ultracurtos, o que permite não destruir a amostra para a análise.

Pelo fato da luz sofrer forte espalhamento na maioria dos tecidos, a profundidade de obtenção de imagens é limitada a poucos milímetros. O OCT 
possui um potencial para funcionar como um tipo de "biópsia óptica", onde a morfologia pode ser avaliada diretamente, em tempo real e sem a necessidade de qualquer preparação prévia das estruturas a serem estudadas (Fujimoto et al., 1995; Fujimoto, 2003;).

Segundo Raele, 2009 o sistema OCT completa uma lacuna deixada por outros métodos de diagnóstico por imagem, como a microscopia Confocal e o ultrasom, conforme apresentado na FIG. 8:

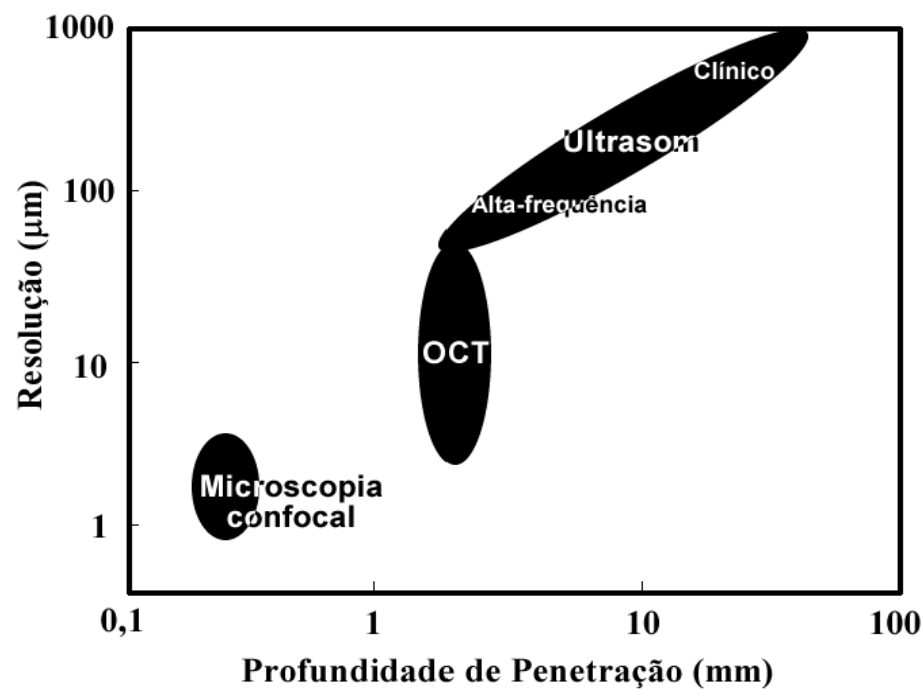

FIGURA 8 - Região de atuação, resolução e profundidade de penetração das técnicas de OCT, microscopia confocal e ultrassom (Raele, 2009).

O sistema OCT utiliza um interferômetro de Michelson e o funcionamento se baseia em uma fonte de luz que é dividida por um divisor de feixe, sendo que uma parte do feixe é direcionada para a amostra e a outra para um espelho do braço de referência. A luz retroespalhada pela amostra e a luz refletida pelo espelho são recombinadas no divisor de feixe gerando um padrão de interferência coletado pelo detector de luz e a interferência entre os dois sinais ocorre apenas quando os seus comprimentos correspondem ao comprimento de coerência da luz, conforme mostra FIG. 9 (Freitas et al., 2010). 


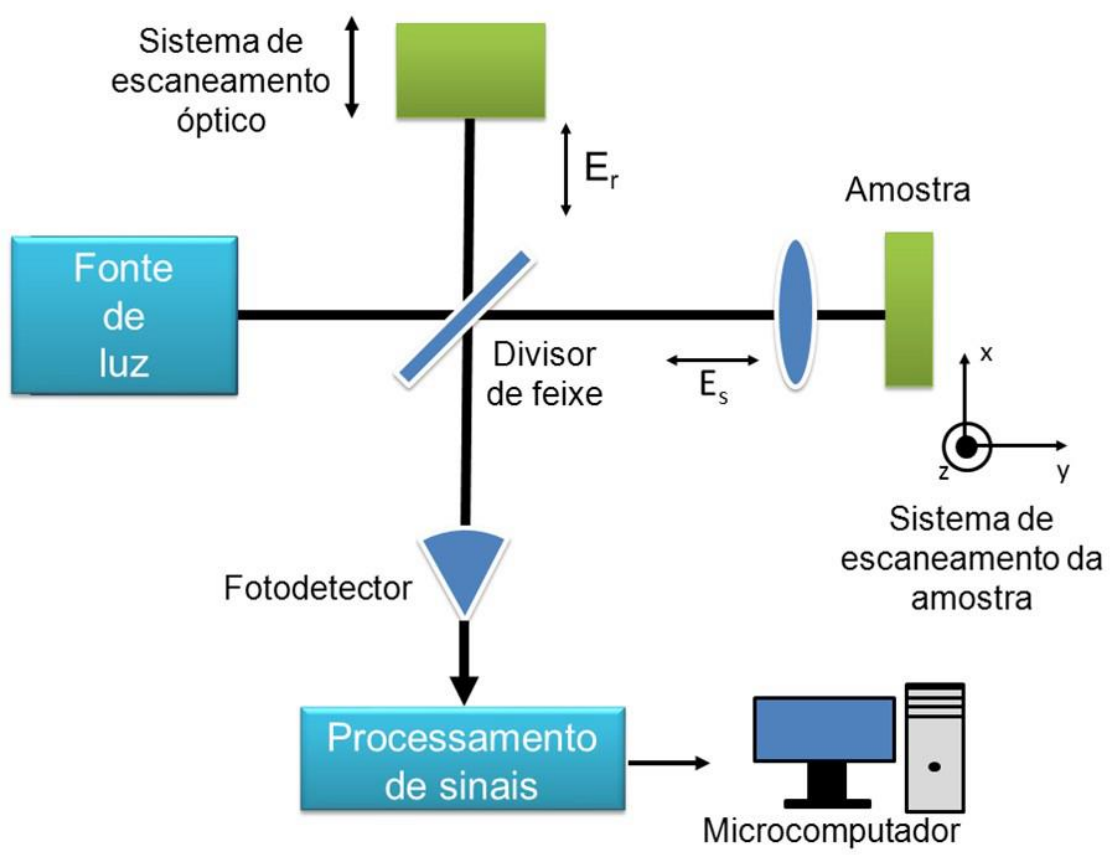

FIGURA 9 - Esquema básico de um sistema OCT (Freitas et al., 2006)

Por meio da alteração do caminho óptico percorrido pela luz até o espelho do braço de referência é possível obter informações provenientes de diferentes profundidades do tecido em estudo. Os sinais de intensidade captados pelo detector são transmitidos a um computador que possibilita a análise dos dados (Cara, 2012; Freitas et al., 2010).

A imagem da secção transversal de uma amostra é produzida de uma forma equivalente ao radar, onde um feixe de luz é lançado no tecido e os perfis de reflexão de várias posições transversais são gravados no computador. O resultado é uma representação bidimensional da secção transversal do tecido. A representação mostra-se em uma escala da cor cinza ou por cores falsas (não representa as cores reais do tecido), onde a cor branca indica um estouro de escala, ou seja, representa um espalhamento acima do superior, a cor preta demonstra regiões onde não há sinal (limiar inferior) e as outras cores seguem o padrão RGB (Red, Green, Blue), onde temos o vermelho como maior sinal, e sucessivamente pelas cores laranja, amarelo, azul, verde e violeta (menor sinal) (Fujimoto et al., 1995).

São inúmeras as aplicações da técnica de OCT, como na área de odontologia a técnica tem sido utilizada para detecção de lesões iniciais cariosas no esmalte dentário (Popescu, 2008). Na oftalmologia, o sistema OCT permite 
obter imagens bem definidas da estrutura da retina e possibilita alcançar um diagnóstico de degeneração macular, glaucoma e edema macular (Budenz et al., 2007; Huang, 1991). Outra aplicação é na detecção de imagem intravascular e para o diagnóstico, como por exemplo de lesões coronarianas de alto risco (Brezinski et al., 1996; Brezinski, 2006;). Alguns autores demonstram bons resultados da técnica para o diagnóstico de doenças degenerativas, como a osteoartrite.

Outra área que poderá ser promissora para a aplicação de OCT é a detecção e tratamento de células tumorais, pois um trabalho publicado por Meer et al., em 2010 utilizou a técnica para determinar as propriedade ópticas dos fibroblastos humanos que foram induzidos a apoptose e necrose e este estudo poderá servir de modelo para acompanhamento do tratamento de células tumorais.

Em 2012, Martinho Junior, utilizou a técnica de OCT para avaliar os efeitos da radioesterilização no tecido cartilaginoso e por meio do cálculo do coeficiente de atenuação óptica total avaliou os efeitos da preservação e radioesterilização em cartilagem humana e verificou que esta grandeza pode ser utilizada para prognosticar a qualidade mecânica do tecido.

\subsubsection{Tomografia por Coerência Óptica sensível à polarização}

A Tomografia por Coerência Óptica sensível à polarização (PS-OCT) é um modo funcional de OCT, que se baseia na variação do ângulo de incidência da iluminação e fornece dados sobre o estado de polarização da luz retroespalhada. Em 1992, Hee et al., demonstrou que o PS-OCT é capaz de detectar modificações na polarização do retroespalhamento da luz, revelando propriedades birrefringentes, ou seja, mapear a orientação de estruturas biológicas com um alto grau de organização como a queratina, mielina e colágeno. Pelo fato da velocidade de uma onda ser dependente do índice de refração, a luz incidente sobre um meio birrefringente será dividida em feixes normais e extraordinários e podem se propagar por diferentes trajetórias, com velocidades diferentes, devido à diferença nos índices de refração (Prasad, 2003). A sensibilidade à polarização pode ser vista pela presença de "franjas" nas imagens, que ocorrem devido ao acúmulo de fase de $\pi$ radianos do vetor resultante do campo eletromagnético.

O PS-OCT revela dados sobre a organização e integridade da matriz de colágeno e quando ocorrem modificações na birrefringência do tecido, significa 
possíveis alterações na funcionalidade, estrutura, ou na viabilidade dos tecidos (de Boer et al., 1997).

Em 2009, Jacobs \& Matcher, utilizaram a técnica para avaliar o quanto o processo de desmineralização óssea pode afetar a organização das fibras de colágeno e demonstraram que a polarização pode ser detectada melhor em tecidos desmineralizados, porém também pode ser avaliada em tecidos mineralizados. Martinho Junior (2012) utilizou a técnica de PS-OCT para avaliar os efeitos da radioesterilização no tecido cartilaginoso e observou a presença de birrefringência nos diferentes tipos de preservações e doses, no entanto o mesmo autor relata a necessidade de modelos matemáticos para quantificar tais modificações.

\subsubsection{Espectroscopia Raman}

A espectroscopia Raman é uma técnica de espectroscopia vibracional utilizada para avaliar o espalhamento da luz em moléculas biológicas, fármacos, nanotubos de carbono, fósseis e outros (Dresselhaus, 2005; Mamede, 2006; Morris \& Mandair, 2011; Silva, 2013). Os movimentos vibracionais dentro das moléculas levam a uma pequena perda de energia da luz sendo espalhados em comprimentos de ondas mais longos. A diferença entre o comprimento de luz espalhada e o da luz incidente corresponde a vibrações moleculares que leva a bandas de deslocamentos de frequências características no espectro Raman (conforme FIG. 10). Esses deslocamentos são representados em unidades de número de onda correspondente à energia vibracional $\left(\mathrm{cm}^{-1}\right)$ (Morris \& Mandair, 2011).

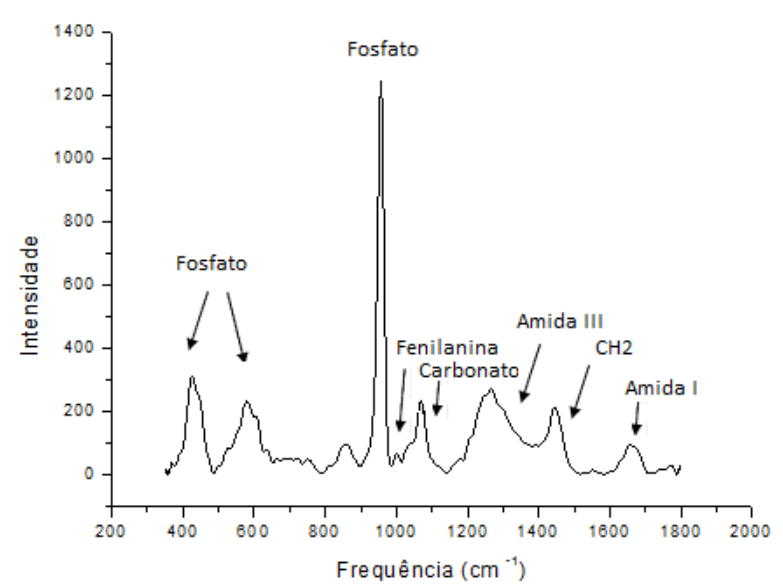

FIGURA 10 - Deslocamentos característicos do espectro Raman referente ao tecido ósseo que são representados em unidades de número de onda correspondente à energia vibracional $\left(\mathrm{cm}^{-1}\right)$ (espectro do próprio autor). 
Esta técnica tem sido utilizada para avaliar as alterações na composição óssea, ocasionada por fatores como: idade, doenças ou lesões, pois este tipo de espectroscopia confocal permite avaliar a identidade mineral e a qualidade dos componentes orgânicos da matriz (Inzana et al., 2013; Morris \& Mandair, 2011). As principais bandas de Raman para o tecido ósseo incluem modos de vibração para o fosfato, carbonato e fosfato de monoidrogênio. As intensidades, posições e formas das bandas fornecem informações sobre o estado de maturação, bem como a composição anormal resultante de defeitos genéticos, doenças ou outras fontes de modificação óssea (Morris \& Mandair, 2011; Yamamoto et al., 2012). Mandair et. al, utilizou a técnica de espectroscopia Raman para prever e diagnosticar uma fragilidade óssea em pacientes com osteoporose no período pós menopausa. Em 2012, Yamamoto et al., utilizou a técnica para avaliar as alterações no tecido ósseo após o processamento por radiação ionizante e o mesmo autor avaliou diferentes espectros para detectar a qualidade óssea.

\subsubsection{Propriedades Mecânicas}

$\mathrm{Na}$ literatura, existem diversos trabalhos que mensuram as propriedades mecânicas de tecidos ósseos, após serem esterilizados por diferentes doses, sendo o objetivo principal quantificar modificações relacionadas com a resistência mecânica. A importância destes testes está centrada na aplicação posterior dos tecidos, já que irão atuar como suporte estrutural em partes do esqueleto.

As propriedades mecânicas dos materiais podem ser verificadas por projetos experimentais realizados em um laboratório e durante os ensaios alguns fatores devem ser considerados, como a natureza da carga aplicada e a sua duração, bem como as condições ambientais (Calister, 2008). Existem alguns tipos de carga que podem ser aplicadas, como a de tração, cisalhamento, flexão, torção e compressão.

A tração é caracterizada por forças semelhantes e opostas aplicadas na direção externa da estrutura e sob essas cargas a estrutura tende a alongar-se e estreitar-se (FIG 11). O cisalhamento é representado pela aplicação de cargas paralelas à superfície da estrutura, contudo a deformação dentro do material ocorre de forma tangencial. A compressão se caracteriza por cargas iguais e opostas 
aplicadas na direção interna da estrutura e a tendência é que esta se encurte e alargue (Marchetti et al., 2007).

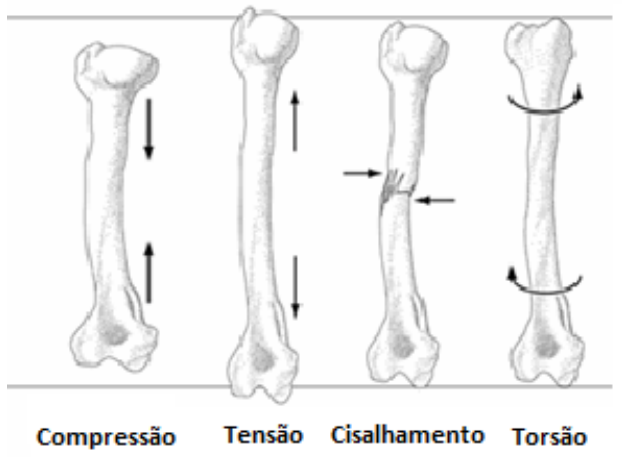

FIGURA 11- Modelo do direcionamento das diferentes cargas. http://www.gustrength.com/newsletter:tension-compression-shear-torsion.

Em particular, o tecido ósseo submetido a uma força de compressão (FIG. 12) irá absưriver energia e deformar-se até a ruptura.

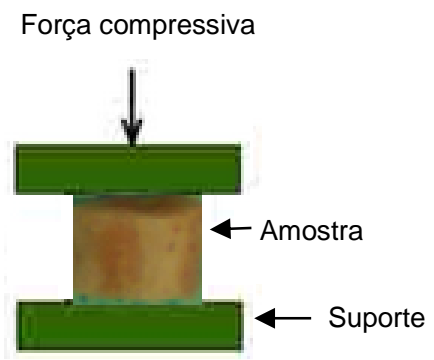

FIGURA 12 - Amostra submetida ao ensaio mecânico de compressão

Os ensaio mecânico de compressão fornece dados da resistência máxima a compressão, resistência à ruptura e deformação ocorrida na amostra durante o teste (FIG.13). 


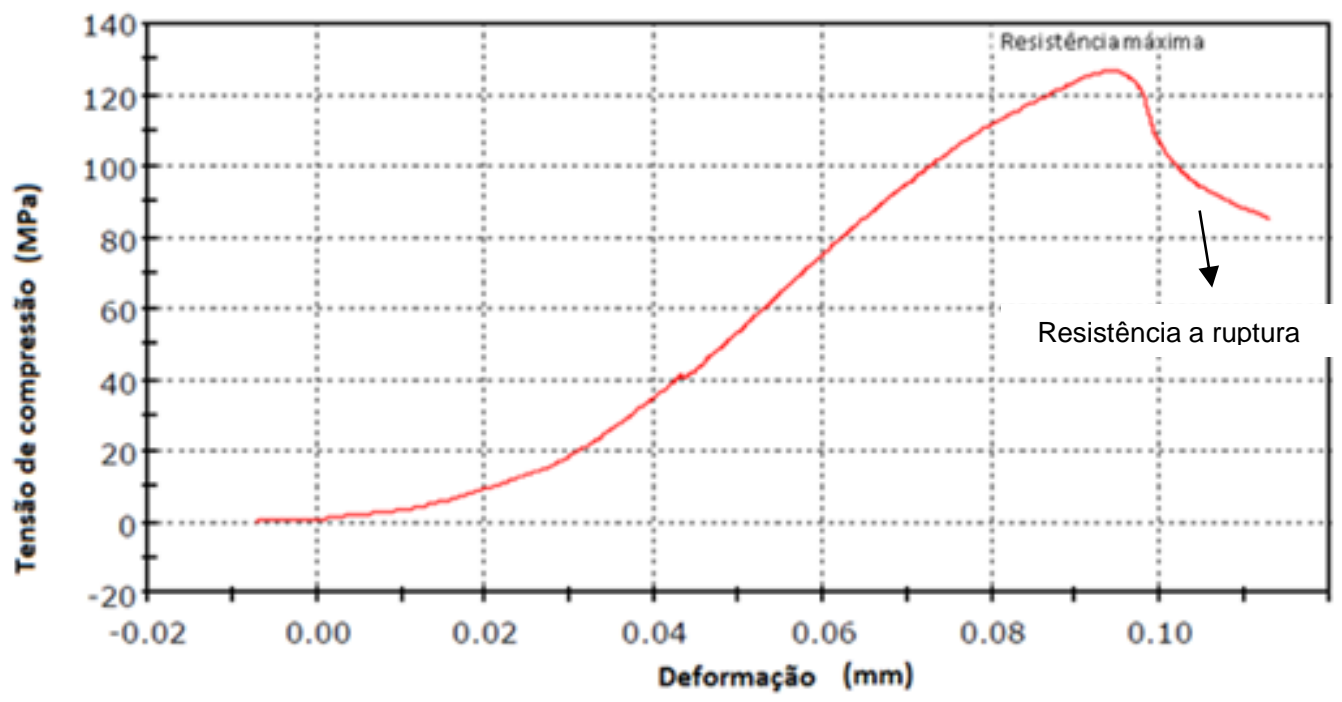

FIGURA 13 - Gráfico obtido pelo software Bluehill da máquina de ensaios mecânicos universal (Instron). As setas indicam os pontos de resistência máxima e de ruptura. 


\section{MATERIAIS E MÉTODOS}

\subsection{Aprovação do Comitê de Ética}

Este projeto foi encaminhado ao Comitê de Ética em Pesquisas da Faculdade de Saúde Pública da Universidade de São Paulo e aprovado sob o protocolo de pesquisa $n^{\circ} 2311$ de 31 de janeiro de 2012 (APÊNDICE 3).

\subsection{Obtenção das amostras}

Foram obtidas oito fíbulas, de quatro doadores humanos, por meio de uma parceria com Banco de Tecidos Musculo-esqueléticos do Instituto de Traumatologia e Ortopedia do Hospital das Clínicas da Faculdade de Medicina da Universidade de São Paulo.

A idade dos doadores variou entre 32 e 53 anos (média de 47 anos). No QUADRO 2 observa-se a variação de idade, sexo, peso e altura de cada doador. Todas as doações por parte dos Bancos de Tecidos estão de acordo com as determinações da ANVISA descritas na Resolução da Diretoria Colegiada - RDC 220 de 27 de dezembro de 2006, item 23.2 e a portaria do Sistema Nacional de Transplantes (SNT) no 2600 de 21 de outubro de 2009, Seção 9, art. 156 (APÊNDICE 4).

QUADRO 2 - Dados dos doadores

\begin{tabular}{|l|l|l|c|c|}
\hline DOADOR & IDADE & SEXO & $\begin{array}{c}\text { PESO } \\
(\mathbf{K g})\end{array}$ & $\begin{array}{c}\text { ALTURA } \\
\text { (metros) }\end{array}$ \\
\hline A & 50 anos & masculino & 70 & 1,70 \\
\hline B & 32 anos & feminino & 70 & 1,65 \\
\hline C & 53 anos & masculino & 75 & 1,75 \\
\hline D & 53 anos & feminino & 80 & 1,60 \\
\hline
\end{tabular}

\subsection{Processamento das amostras}

As amostras foram processadas em três etapas denominadas: processamento mecânico, cortes e processamento químico. O processamento mecânico consiste na remoção (por auxílio de um bisturi e osteótomo) de tecidos adjacentes, como restos sanguíneos, periósteo, tecido subcutâneo, músculos, fáscias e tecido fibrótico. Após o processamento mecânico, foram retiradas as epífises das fíbulas e as diáfises foram cortadas perpendiculares ao eixo 
longitudional por meio de uma serra elétrica manual, obtendo-se anéis com $1 \mathrm{~cm}$ de altura. Após este procedimento, foi realizado o processamento químico, onde os ossos foram imersos em soluções emulsificantes com base em peróxido de hidrogênio e soluções alcoólicas, sob agitação ultrassônica. Após esses procedimentos as amostras foram colocadas em sacos plásticos estéreis contendo solução fisiológica e as mesmas foram agitadas manualmente por aproximadamente dois minutos. Foram obtidas 48 amostras para congelamento e 48 amostras para liofilização.

\subsection{Identificação das amostras}

As amostras foram identificadas segundo o doador, o tipo de preservação e dose de radiação recebida, sendo 0 (controle), 15, 25 e 50 kGy.

\subsection{Fluxograma de trabalho}

O fluxograma (FIG. 14) representa a ordem dos experimentos:

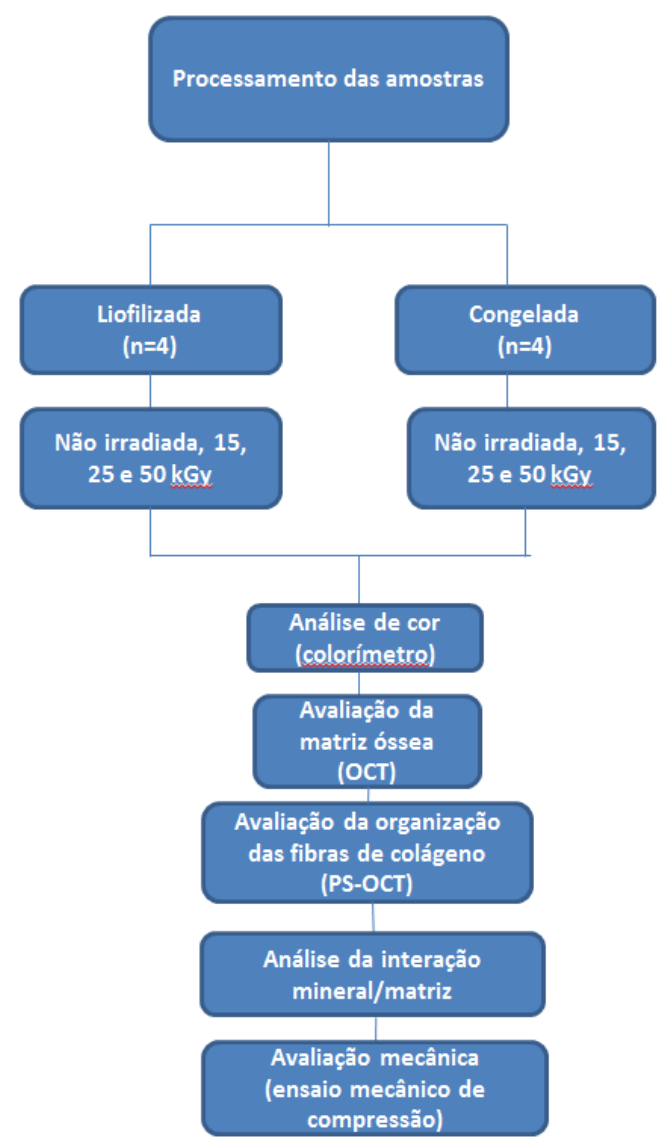

FIGURA 14 - Fluxograma das etapas de trabalho 


\subsection{Preservação}

\subsubsection{Liofilização}

A liofilização, das 48 amostras processadas, foi realizada em um sistema automatizado composto por câmara de liofilização (Labconco, modelo 79480) e câmara de condensação (Labconco, modelo 77530). As amostras congeladas a $80^{\circ} \mathrm{C}$ foram colocadas no interior da câmara de liofilização a uma temperatura de $40{ }^{\circ} \mathrm{C}$. A liofilização primária foi realizada a uma pressão de vácuo de $8 \times 10^{-3} \mathrm{mBar}$ e a uma temperatura de $-30{ }^{\circ} \mathrm{C}$ por seis horas. Posteriormente foi realizada a liofilização secundária a uma temperatura de $5{ }^{\circ} \mathrm{C}$ e vácuo de $7 \times 10^{-3} \mathrm{mBar}$. $\mathrm{O}$ limite estabelecido de umidade residual após a liofilização foi de até $6 \%$ (LUCHSINGER \& JUDA, 2008), medido no analisador de umidade (Ohaus, modelo MB45). Para a realização dos experimentos as amostras foram reidratadas em solução fisiológica por 10 minutos.

\subsubsection{Congelamento}

Após o processamento, 48 amostras foram congeladas e armazenadas no freezer $-70{ }^{\circ} \mathrm{C}$ e antes da realização dos ensaios as mesmas foram descongeladas em temperatura ambiente por 60 minutos.

\subsection{Irradiação das amostras}

O processo de irradiação das amostras foi realizado no Centro de Tecnologia das Radiações (CTR) do Instituto de Pesquisas Energéticas e Nucleares (IPEN-CNEN/SP). As amostras congeladas e liofilizadas foram irradiadas com raios gama, por fontes de ${ }^{60} \mathrm{Co}$ no Irradiador Multipropósito tipo compacto e receberam doses de 15 kGy, 25 kGy e 50 kGy, além do controle não irradiado. Para o controle de dose foram utilizados dosímetros poliméricos Red Perspex (5-50 kGy). Para evitar a variação da temperatura, as amostras congeladas a $-70^{\circ} \mathrm{C}$ foram irradiadas em gelo seco e as amostras liofilizadas foram irradiadas na presença de elementos refrigerantes. Para cada dose foram irradiadas doze amostras congeladas e doze amostras liofilizadas, além de doze amostras para cada controle não irradiado, totalizando 96 amostras. 


\subsection{Colorímetro}

Foi utilizado um colorímetro, modelo Spectro-guide 45/0 gloss, marca BYK. As amostras foram analisadas nos ângulos de $0^{\circ}$ e $180^{\circ}$ (FIG.15). O espectrofotômetro spectro-guide $45 / 0$ possui um único e patenteado princípio de medição para conseguir uma iluminação circunferencial 100\%.

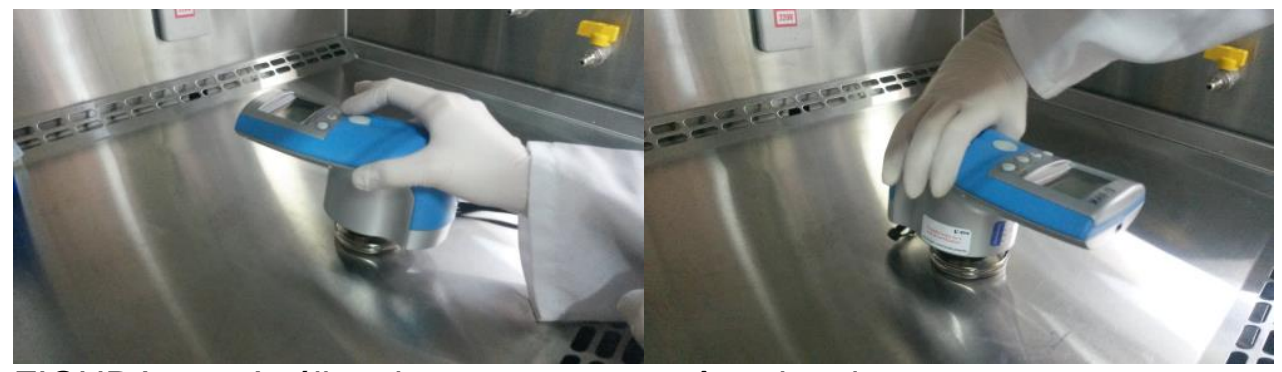

FIGURA 15 - Análise das amostras nos ângulos de $0^{\circ}$ e $180^{\circ}$.

\subsection{Tomografia por Coerência Óptica}

O sistema OCT utiliza como fonte óptica um led superluminescente (SLD), com largura espectral de $100 \pm 5 \mathrm{~nm}$ e centrado em $930 \mathrm{~nm}$, com potência de 2 $\mathrm{mW}$ na amostra. As imagens com resolução lateral 6,0 microns e longitudinal de e 4,1 microns foram geradas pelo deslocamento do ponto de incidência na amostra por espelhos acoplados a um galvanômetro. A luz foi focalizada na amostra com uma lente de $5 \mathrm{~cm}$ de distância focal. Os dados foram adquiridos e armazenados em microcomputador para posterior processamento (OCP930SR, Thorlabs Inc. NJ, USA). Foram obtidas cinco imagens de cada uma das amostras, para o posterior cálculo do coeficiente de atenuação óptica total (FIG.16).

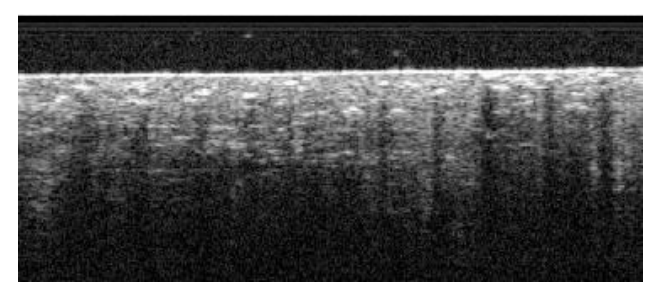

FIGURA 16 - Imagem obtida por Tomografia por Coerência Óptica

\subsection{Cálculo do Coeficiente de Atenuação Óptica Total}

O cálculo do coeficiente foi realizado por meio de um programa computacional dedicado, desenvolvido pelo Dr. Anderson Zanardi de Freitas na plataforma LabView 8.0, National Instruments. 
Conforme podemos notar na FIG. 17, o programa permite selecionar uma região de interesse $(\mathrm{ROI})$, como pode ser visto na parte superior desta imagem, por meio das linhas branca e vermelha. O ROI foi previamente determinado e padronizado para todas as amostras, entre 1500 e 4500 microns. Depois de selecionada a região de interesse e colocado o índice de refração do tecido ósseo $(\eta=1,56)$ o programa calcula automaticamente o coeficiente de atenuação óptica.

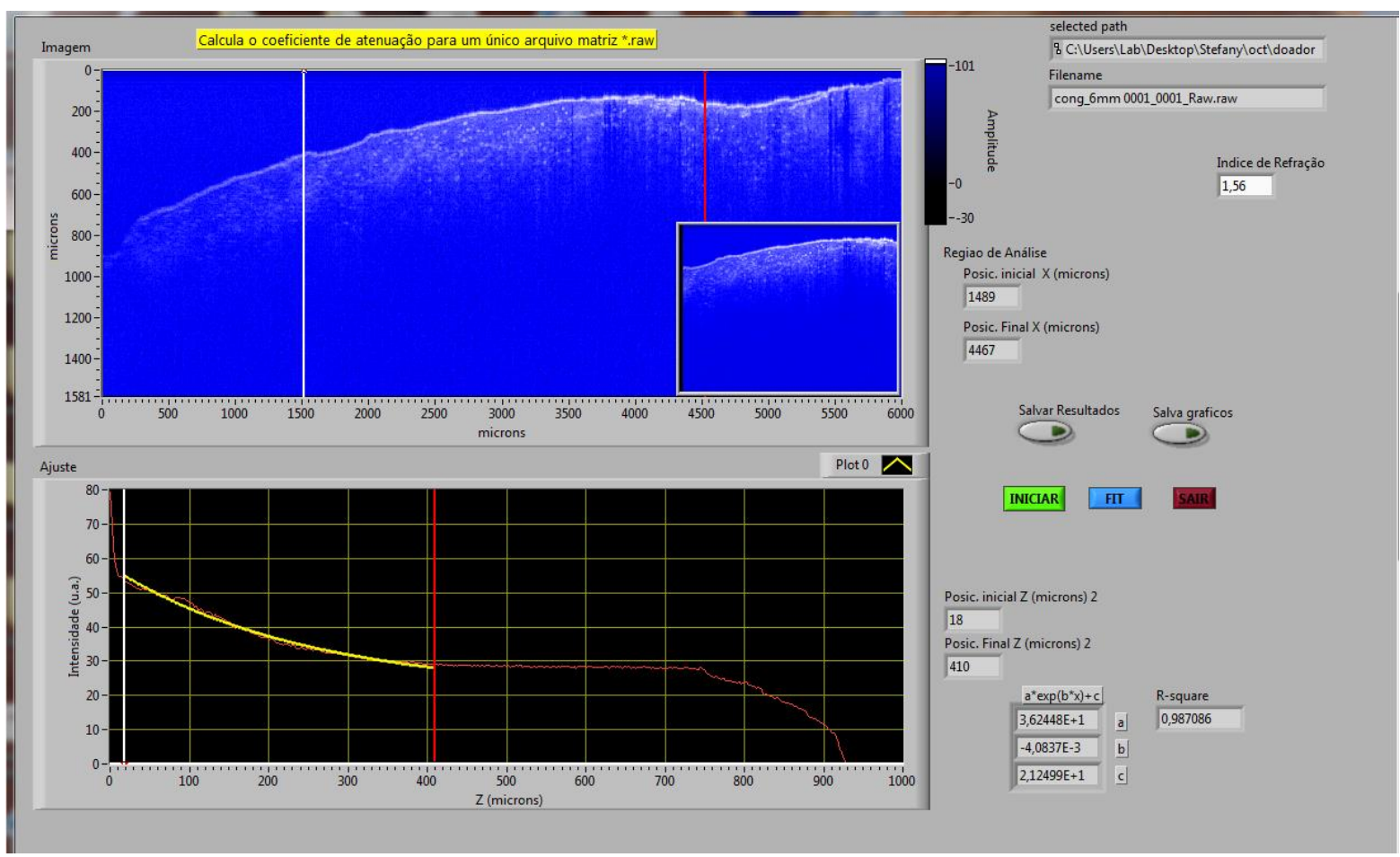

FIGURA 17 - Interface do programa utilizado para o cálculo do coeficiente de atenuação óptica total.

\subsection{Tomografia por Coerência Óptica sensível à Polarização}

O equipamento OCT 1300 SS com um módulo de polarização PS-OCT 1300, utilizado para o ensaio de Tomografia por Coerência Óptica sensível à polarização, possui um comprimento de onda centrado em $1325 \mathrm{~nm}$ com $10 \mathrm{~mW}$ de potência na amostra. De cada amostra foram obtidas três imagens (em ângulo de incidência da luz de aproximadamente $45^{\circ}$ em relação ao longo do eixo).

A fase acumulada (ou formação de franjas) é representada numa escala de cores falsas como apresentada na FIG. 18:

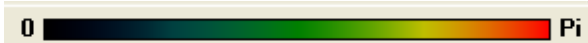

FIGURA 18 - Padrão de cores utilizado para representar a fase acumulada. 


\subsection{Espectroscopia Raman}

Foi utilizado um espectrômetro Raman acoplado a um microscópio Confocal, modelo XploRA ${ }^{T M}$ e fabricado pela Horiba Jobin Yvon. Os espectros Raman foram obtidos com excitação em 785 nm e a potência do laser foi de 50\%.

Os dados foram obtidos por um sistema de comando e aquisição de dados. Os resultados foram analisados pelo programa Origin 8 e foi calculada a área dos espectros referente ao Fosfato $\left(981,9-925,7 \mathrm{~cm}^{-1}\right)$ e Amida $\mathrm{l}\left(1,716.3-1,541.2 \mathrm{~cm}^{-1}\right)$.

\subsection{Ensaio Mecânico de Compressão}

Os testes de compressão foram realizados na Máquina de Ensaio Universal Instron Modelo 5567, do Centro de Tecnologia das Radiações do Instituto de Pesquisas Energéticas e Nucleares (IPEN - CNEN/SP). Esta máquina consiste em um arranjo constituído por duas travessas (uma fixa e outra móvel), uma célula de carga, um mecanismo de direcionamento, acessórios de fixação dos corpos de prova. A máquina estava conectada a um computador e os ensaios foram analisados pelo software Bluehill.

Para o ensaio mecânico foi utilizado um módulo de carga de $10 \mathrm{kN}$ e a velocidade de aproximação das prensas foi de $10 \mathrm{~mm} / \mathrm{min}$ em temperatura ambiente. Antes dos testes, as amostras em formato de anel (aproximadamente cilindrico) foram medidas com auxílio de paquímetro em três pontos distintos, para obter uma média dos diâmetros, tanto externo quanto interno (FIG. 19).

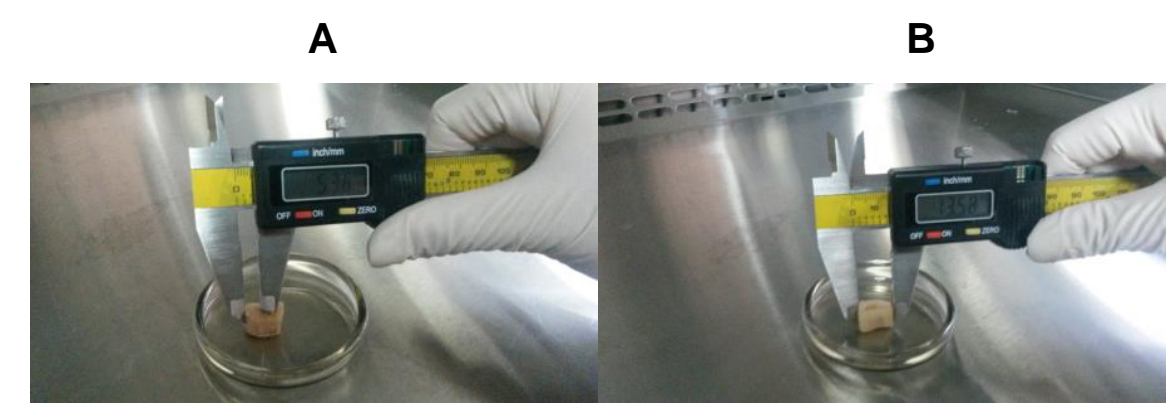

FIGURA 19 - A. Medida do diâmetro interno; B. Medida do diâmetro externo.

\subsection{Análise estatística}

Os resultados foram comparados estatisticamente pelo método one-Way Anova e seguido do teste de Tukey e os que apresentaram diferença estatística $(p<0,05)$ foram marcados nos gráficos com o símbolo $\left(^{*}\right)$. 


\section{RESULTADOS}

\subsection{Colorímetro}

Para a avaliação das modificações de cor ocasionadas pela radiação ionizante foi utilizada a técnica de colorimetria, que permite avaliar as mudanças de cor em substâncias sólidas. Os parâmetros utilizados foram $a^{*}, b^{*}$ e $L^{*}$ obtidos da escala CIELAB, 1976. O eixo $a^{*}$, quanto mais positivo, refere-se ao aumento da cor vermelha e quanto mais negativo, refere-se ao aumento da coloração verde. Igualmente o eixo $\mathrm{b}^{*}$, quanto mais positivo, refere-se ao aumento da cor amarela $\mathrm{e}$ quanto mais negativo refere-se ao aumento da coloração azul. $O$ eixo $L^{*}$ corresponde à luminosidade e varia de preto (0) a branco (100) (conforme a FIG. 7, item 3.6.5).

Nas FIGURAS 20, 21 e 22 se observa as diferenças nesses parâmetros nas amostras congeladas e liofilizadas, irradiadas nas diferentes doses:

A

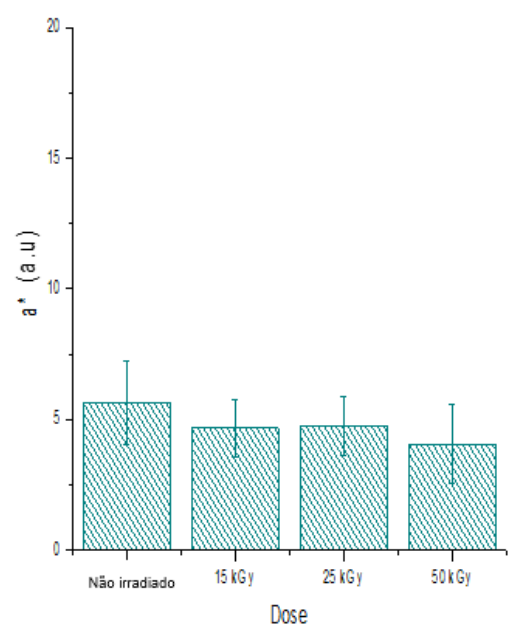

B

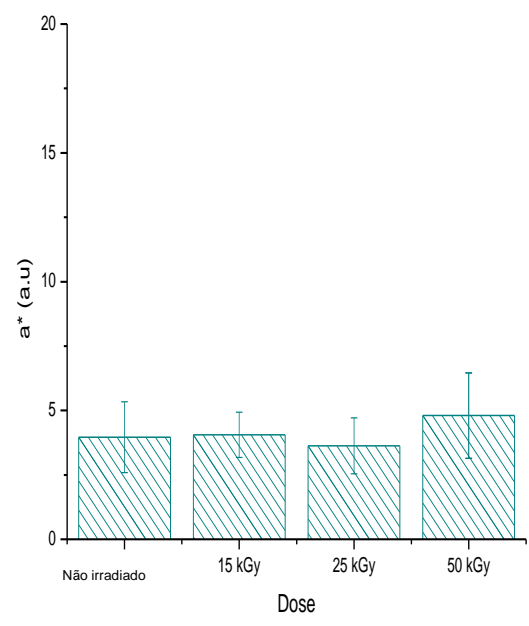

FIGURA 20 - A) Parâmetro a* das amostras congeladas e irradiadas nas diferentes doses de 15,25 e 50 kGy B) Parâmetro a* das amostras liofilizadas e irradiadas nas diferentes doses de 15,25 e 50 kGy.

Na FIG. 20-A para as amostras congeladas, observamos que não ocorreram diferenças estatisticamente significativas para o parâmetro $\mathrm{a}^{*}$ quando comparamos as diferentes doses em relação ao controle. Para as doses de 15, 25 e $50 \mathrm{kGy}$ ocorreu uma ligeira tendência à diminuição da coloração vermelha. 
Conforme FIG. 20-B para as amostras liofilizadas, observamos que não ocorreram diferenças estatisticamente significativas para o parâmetro $a^{*}$ quando comparamos as diferentes doses em relação ao controle. Para a dose de 50 kGy ocorreu uma tendência ao aumento da coloração vermelha.

A

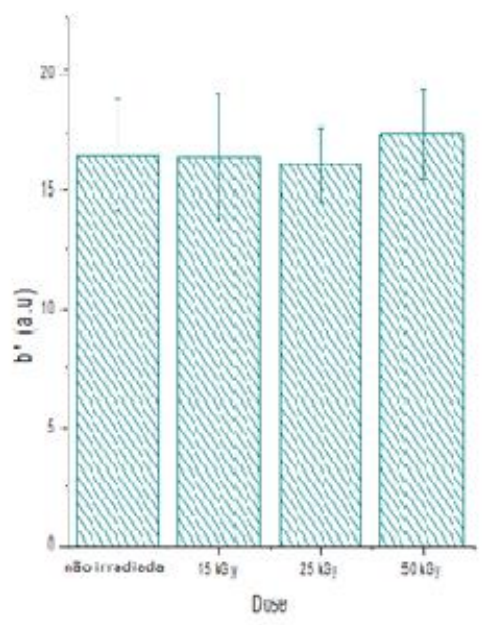

B

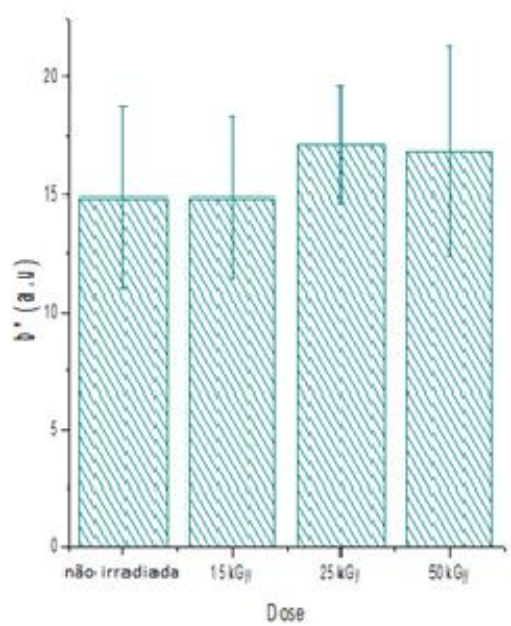

FIGURA 21 - A) Parâmetro $b^{*}$ das amostras congeladas não irradiadas e irradiadas nas diferentes doses de 15, 25 e 50 kGy B) Parâmetro $b^{*}$ das amostras liofilizadas não irradiadas e irradiadas nas diferentes doses de 15, 25 e 50 kGy.

Na FIG. 21-A observamos que não ocorreram diferenças estatisticamente significativas para o parâmetro $b^{*}$ das amostras congeladas quando comparadas ao controle. No entanto, observa-se uma ligeira tendência ao aumento do parâmetro b* nas amostras irradiadas com a dose de 50 kGy.

Conforme FIG. 21-B para as amostras liofilizadas, observamos que não ocorreram diferenças estatisticamente significativas para o parâmetro $b^{*}$ quando comparamos as diferentes doses em relação ao controle. Nas doses de 25 e 50 kGy ocorreu uma tendência ao aumento da coloração amarela. 
A

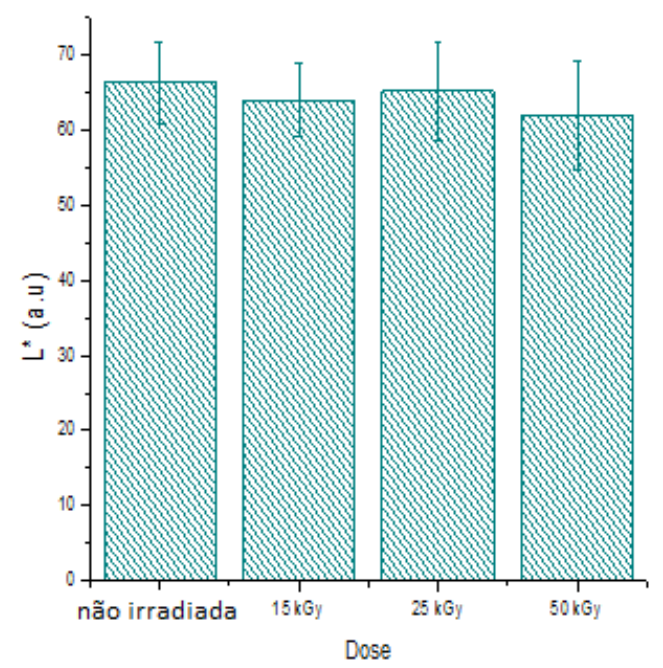

B

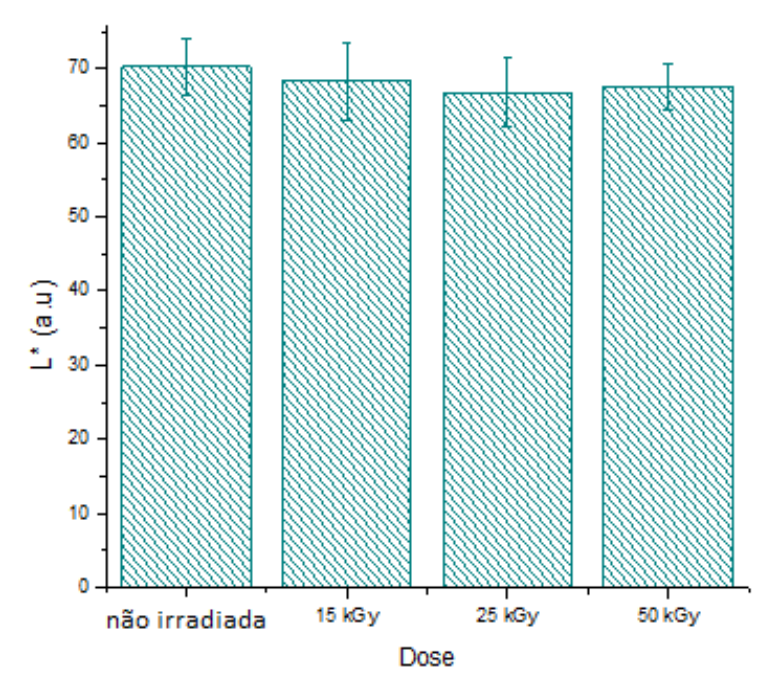

FIGURA 22 - A) Parâmetro $L^{*}$ das amostras congeladas não irradiadas e irradiadas nas diferentes doses de 15, 25 e 50 kGy B) Parâmetro $L^{*}$ das amostras liofilizadas não irradiadas e irradiadas nas diferentes doses de 15, 25 e 50 kGy.

Observa-se na FIG. 22-A que não ocorreram diferenças estatisticamente significativas para o parâmetro $L^{*}$ nas amostras congeladas quando comparamos as diferentes doses em relação ao controle. Para as amostras liofilizadas (FIG. 22-B), observamos que não ocorreram diferenças estatisticamente significativas para o parâmetro $L^{*}$ quando comparamos as diferentes doses em relação ao controle, apenas na dose de 50 kGy ocorreu uma tendência à diminuição da luminosidade.

\subsection{Tomografia por Coerência Óptica}

Pode-se observar (FIGURAS 23 e 24) as modificações do coeficiente de atenuação óptica total nas amostras de tecido ósseo preservadas por diferentes métodos e irradiadas nas diferentes doses. 


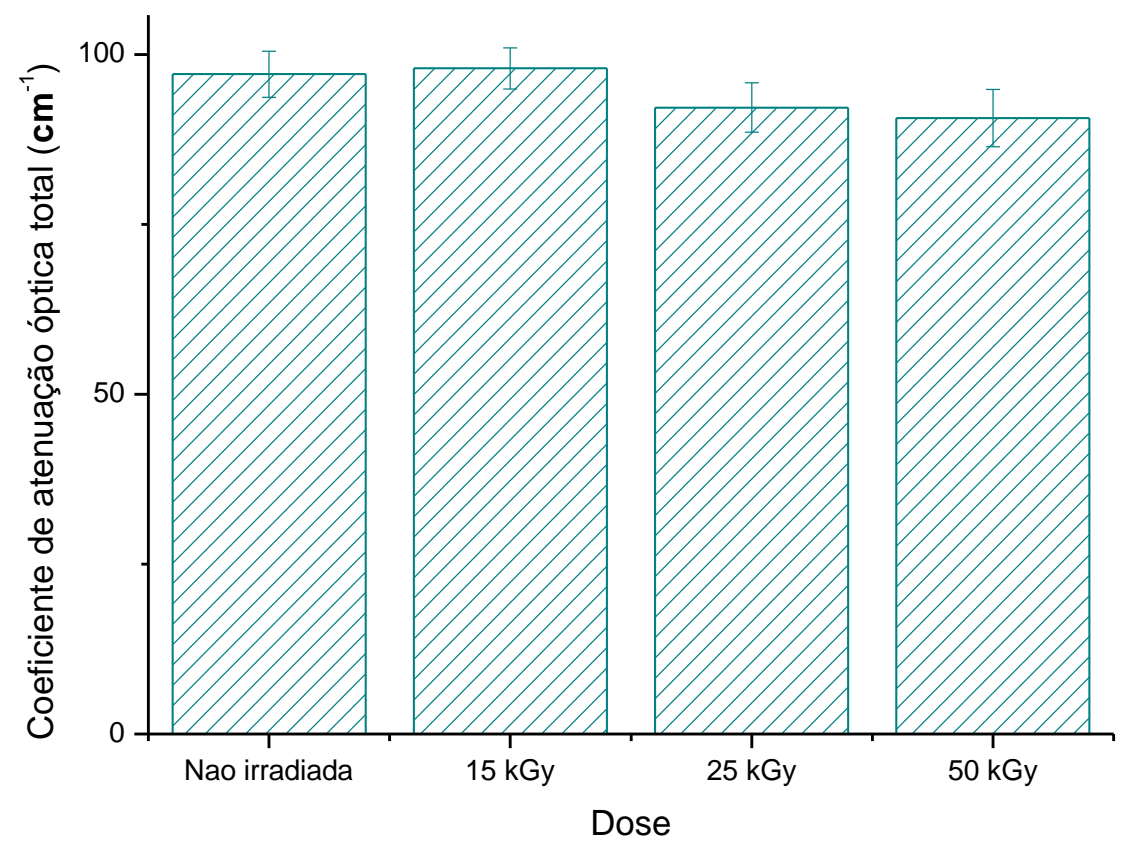

FIGURA 23 - Gráfico das médias dos coeficientes de atenuação ópticas das amostras congeladas não-irradiadas e irradiadas nas doses de 15, 25 e 50 kGy.

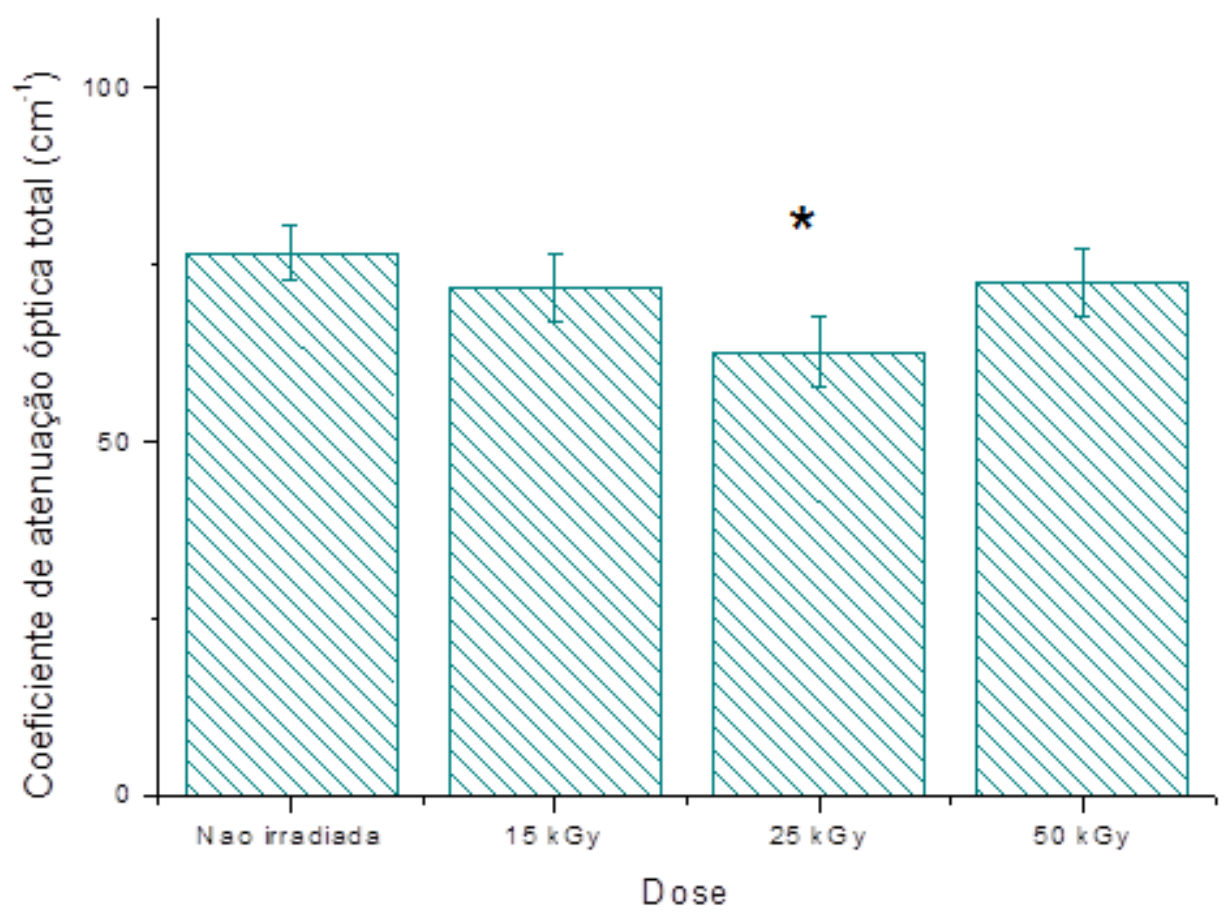

FIGURA 24 - Gráfico das médias dos coeficientes de atenuação ópticas das amostras liofilizadas não-irradiadas e irradiadas nas doses de 15, 25 e 50 kGy. ( ${ }^{*}$ ) indica diferença estatisticamente significativa em relação ao controle $(p<0,05)$. 


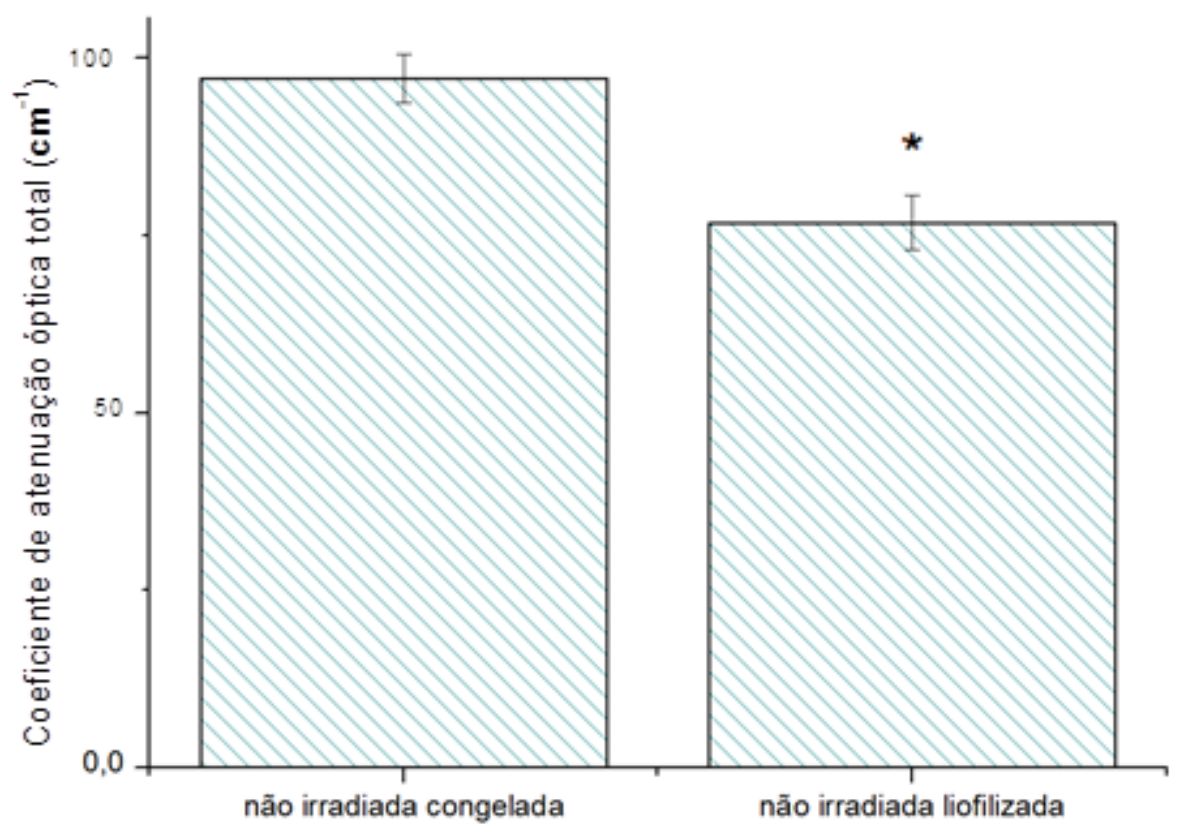

FIGURA 25 - Gráfico das médias dos coeficientes de atenuação ópticas das amostras congeladas e liofilizadas não-irradiadas $\left({ }^{*}\right)$. Indica diferença estatisticamente significativa entre os grupos $(p<0,05)$.

A FIG. 23 refere-se a media do coeficiente de atenuação das amostras congeladas não irradiadas e irradiadas nas diferentes doses. Nas amostras congeladas não foi evidenciado diferença estatisticamente significativa quando comparado ao controle com as diferentes doses.

No gráfico da FIG. 24, observa-se a média do coeficiente de atenuação óptica total das amostras liofilizadas não irradiadas e irradiadas nas diferentes doses. Além da amostra liofilizada e não irradiada já apresentar uma diferença estatisticamente significativa $\left(7,678 \times 10^{-7} \mathrm{~cm}^{-1}\right)$, em relação à amostra congelada $\left(9,713 \times 10^{-7} \mathrm{~cm}^{-1}\right)$, a dose de $25 \mathrm{kGy}$ apresentou uma diferença estatisticamente significativa quando comparada ao controle não irradiado e liofilizado.

O gráfico da FIG. 25 representa a média do coeficiente de atenuação óptica total das amostras congeladas não irradiadas e liofilizadas não irradiadas, observase que entre os grupos foi constatada uma diferença estatisticamente significativa.

\subsection{Tomografia por Coerência Óptica sensível à Polarização}

A Tomografia por Coerência Óptica sensível à polarização foi utilizada para avaliar a orientação das fibras de colágeno, pois a birrefringência destas foi 
verificada pela presença de regiões claras e escuras, denominadas "franjas". Nas FIG. 26 podemos observar a birrefringência presente no tecido ósseo congelado não irradiado e liofilizado não irradiado e a FIG. 27 apresenta imagens das amostras irradiadas nas diferentes doses de 15, 25 e $50 \mathrm{kGy}$ em ambas as formas de preservação.

Foram obtidas imagens de todas as amostras dos diferentes doadores (APÊNDICE 1 e 2), porém nos resultados a seguir selecionamos algumas imagens que representam os resultados obtidos, semelhantes para todos os doadores.

A

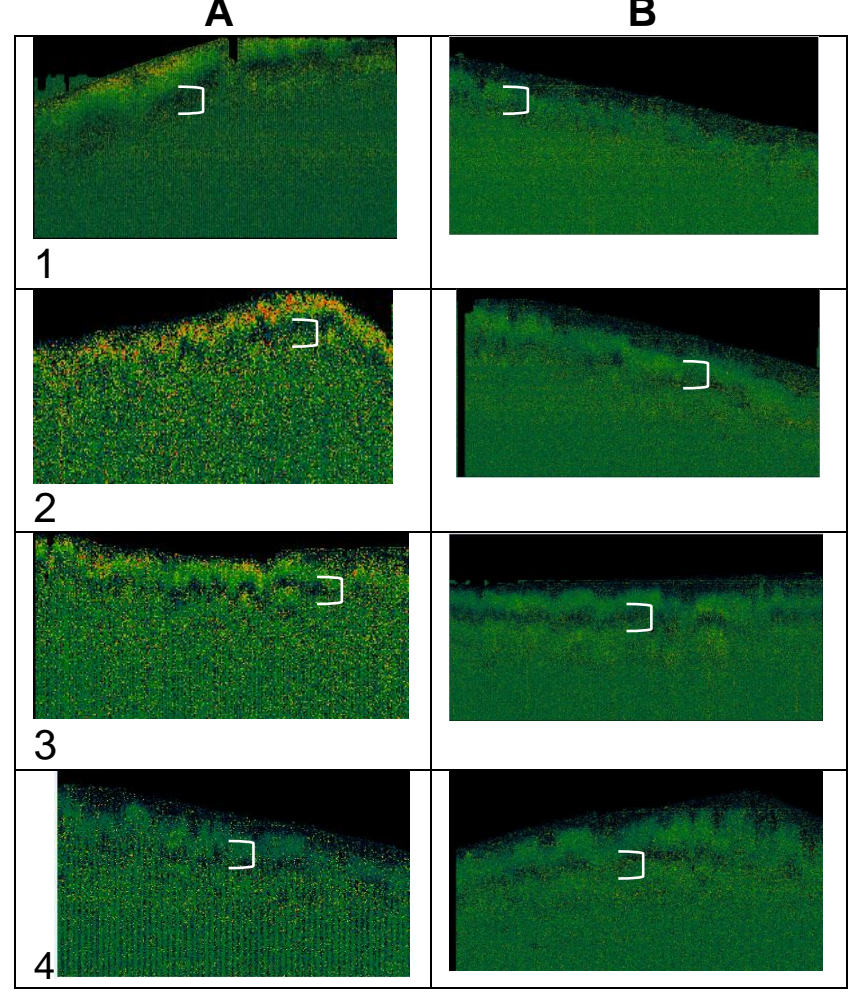

FIGURA 26 - Imagem de PS-OCT das amostras de diferentes doadores, (A) congeladas e não irradiadas; (B) liofilizadas e não irradiadas; (1 a 4) diferentes doadores e ( $\sqsupset$ "Franjas" evidenciadas pela técnica.

Observa-se na imagem acima que em ambas formas de preservação é evidenciado a presença de "franjas" ocasionadas pelo retardo de fase. 
A B

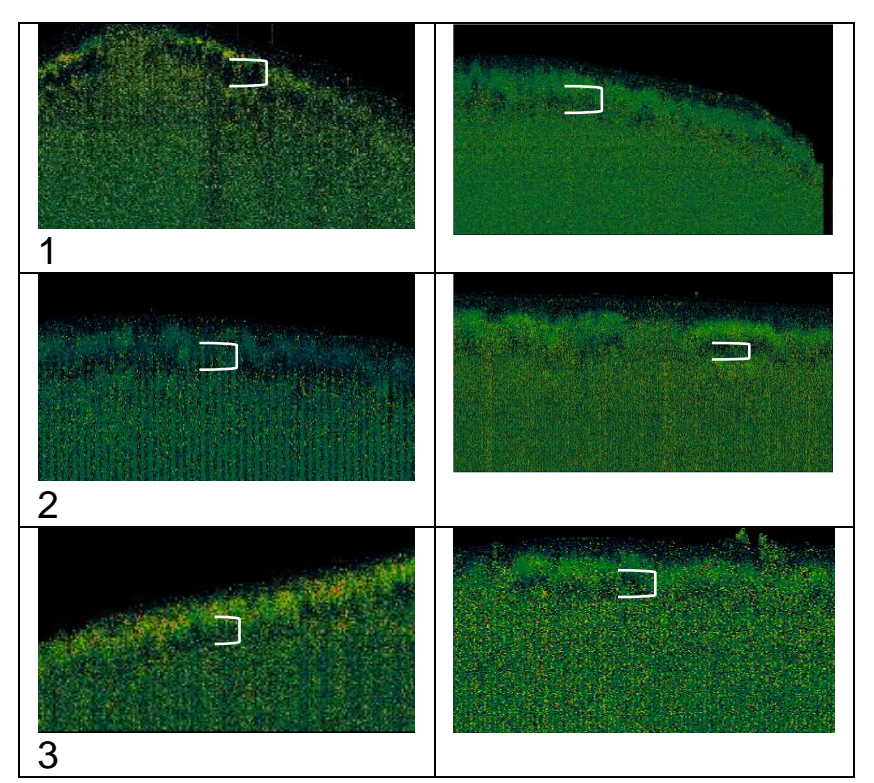

FIGURA 27 - Imagem de PS-OCT das amostras congeladas (A) e liofilizadas (B), irradiadas na dose de 15 kGy (1), 25 kGy (2) e 50 kGy (3).

Observa-se nas imagens acima a formação de "franjas" que representam o retardo de fase causado pela birrefringência do colágeno. Em ambas as formas de preservação e nas diferentes doses observamos que a birrefringência do colágeno não foi alterada após a preservação e irradiação nas diferentes doses.

\subsection{Espectroscopia Raman}

Para uma melhor compreensão das alterações detectadas na técnica de OCT foi utilizada a técnica de espectroscopia Raman e calculada a razão mineral/matriz nos espectros obtidos, utilizando as áreas de $\mathrm{PO}_{4}{ }^{3-}$ e Amida I, respectivamente.

Nas FIG. 28 A e B observamos a média da razão mineral/matriz em ambas formas de preservação e nas diferentes doses de irradiação. 
A

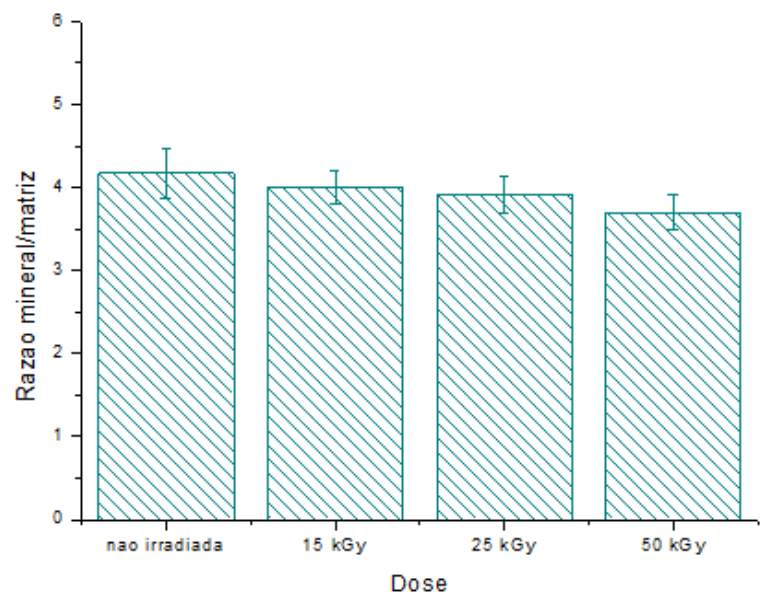

B

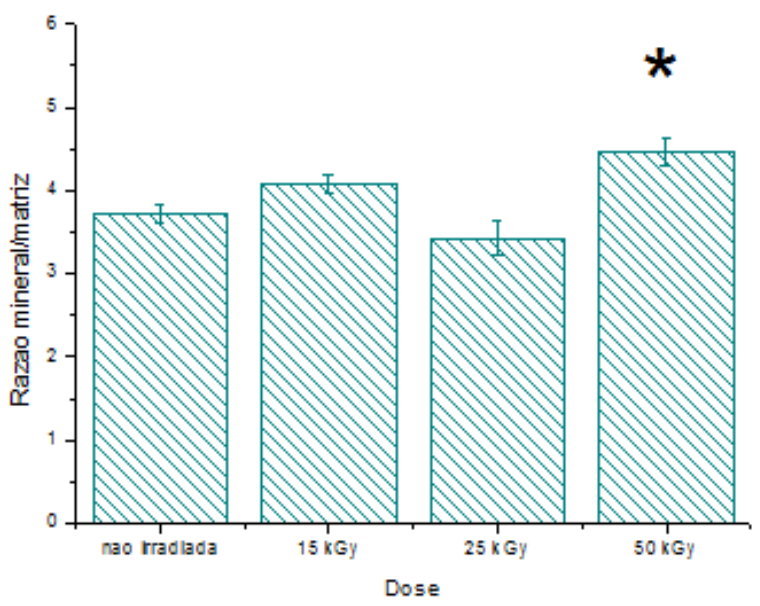

FIGURA 28 - A) Média da razão mineral/matriz das amostras congeladas não irradiadas e irradiadas nas diferentes doses de 15, 25 e $50 \mathrm{kGy} \mathrm{B)} \mathrm{Média} \mathrm{da} \mathrm{razão} \mathrm{mineral/matriz} \mathrm{das}$ amostras liofilizadas não irradiadas e irradiadas nas diferentes doses de 15, 25 e 50 kGy. $\left(^{*}\right)$ Indica diferença estatisticamente significativa entre os grupos $(p<0,05)$.

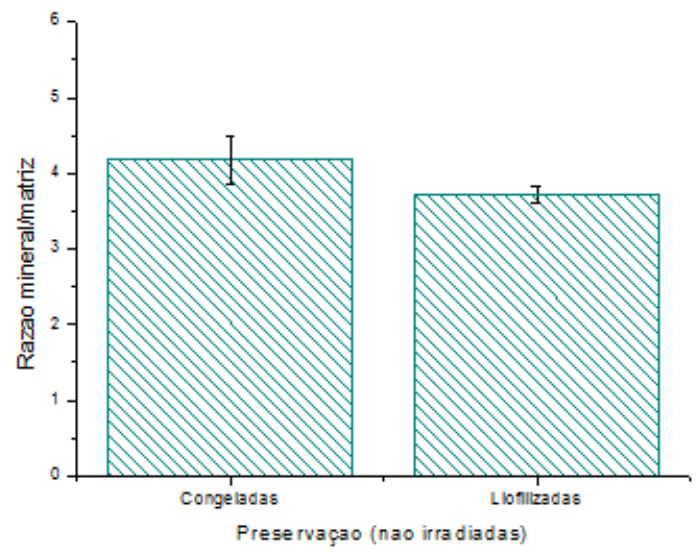

FIGURA 29 - Gráfico da razão mineral/matriz das amostras liofilizadas não-irradiadas e congeladas não-irradiadas.

Pela análise da razão $\mathrm{PO}_{4}{ }^{3-} /$ Amida I, conforme apresentado na FIG.28-A pode-se observar que não houveram diferenças estatisticamente significativas entre as amostras congeladas e irradiadas com as doses de 15, 25 e 50 kGy quando comparadas com o controle, apenas observa-se uma ligeira diminuição destas razões nas amostras irradiadas.

No gráfico da FIG.28-B pode-se verificar que a média da proporção mineral/matriz das amostras liofilizadas não irradiadas (0 kGy) e a média das 
amostras irradiadas com as doses de 15 e 25 kGy, não tiveram diferenças estatisticamente significativas. Apenas a dose de $50 \mathrm{kGy}$ para amostras liofilizadas, demonstrou uma diferença estatisticamente significativa em comparação ao controle.

No entanto, observa-se que, apesar de não ser uma diferença estatisticamente significativa (FIG. 28-B), nas amostras liofilizadas, a dose de 25 kGy apresentaram uma diminuição da média da razão mineral/matriz.

O gráfico da FIG. 29 representa a média da razão mineral/matriz das amostras não irradiadas e preservadas por liofilização e congelamento.

\subsection{Ensaio Mecânico de Compressão}

Nas TABELAS 1, 3, 5 e 7 observamos os valores referentes à resistência máxima, a deformação à resistência máxima, a resistência à ruptura e a carga à resistência máxima das amostras congeladas não irradiadas e irradiadas nas diferentes doses. Nas TABELAS 2, 4, 6 e 8 observamos os valores referentes as amostras liofilizadas não irradiadas e irradiadas nas diferentes doses.

Pode-se observar a grande variação de resistência máxima dos ossos não irradiados, com valores de 99,17 a 165,94 MPa para ossos congelados e 52,98 a 114,02 para ossos liofilizados.

TABELA 1 - Valores do ensaio mecânico de compressão das amostras congeladas e não irradiadas

\begin{tabular}{l|c|c|c|c|c}
\hline $\begin{array}{c}\text { Amostras } \\
\text { congeladas } \\
\begin{array}{c}\text { Não } \\
\text { irradiadas* }\end{array}\end{array}$ & $\begin{array}{c}\text { Resistência } \\
\text { máxima } \\
(\mathrm{MPa})\end{array}$ & \multicolumn{2}{|c|}{$\begin{array}{c}\text { Deformação à } \\
\text { resistência máxima } \\
(\mathrm{mm})\end{array}$} & $\begin{array}{c}\text { Resistência } \\
\text { à rupture } \\
(\mathrm{MPa})\end{array}$ & $\begin{array}{c}\text { Carga ao atingir } \\
\text { a resistência } \\
\text { máxima } \\
(\mathrm{N})\end{array}$ \\
\hline$\underline{\mathrm{A}-1}$ & 108,88 & 0,47 & 4,70 & 78,72 & 8648,91 \\
\hline$\underline{\mathrm{A}-2}$ & 149,62 & 1,49 & 14,9 & 88,79 & 8648,74 \\
\hline$\underline{\mathrm{B}-3}$ & 99,17 & 1,34 & 13,4 & 81,29 & 8723,43 \\
\hline$\underline{\mathrm{C}-1}$ & 165,94 & 9,08 & 90,8 & 83,92 & 7681,47 \\
\hline$\underline{\mathrm{C}-2}$ & 126,28 & 0,94 & 9,4 & 85,25 & 9997,38 \\
\hline$\underline{\mathrm{D}-1}$ & 104,87 & 2,11 & 21,1 & 72,87 & 7307,29 \\
\hline$\underline{\mathrm{D}-3}$ & 123,77 & 1,74 & 17,4 & 68,13 & 8649,84 \\
\hline
\end{tabular}

${ }^{\star}$ As letras $A, B, C$ ou $D$ correspondem aos diferentes doadores e o número corresponde à identificação das diferentes amostras de cada doador. 
TABELA 2 - Valores do ensaio mecânico de compressão das amostras liofilizadas e não irradiadas

\begin{tabular}{l|c|c|c|c|c}
\hline $\begin{array}{l}\text { Amostras } \\
\text { lioflizadas } \\
\text { Não } \\
\text { irradiadas }\end{array}$ & $\begin{array}{l}\text { Resistência } \\
\text { máxima } \\
(\mathrm{MPa})\end{array}$ & \multicolumn{2}{|c|}{$\begin{array}{l}\text { Deformação à } \\
\text { resistência máxima } \\
(\mathrm{mm})\end{array}$} & $\begin{array}{l}\text { Resistência à } \\
\text { ruptura } \\
(\mathrm{MPa})\end{array}$ & $\begin{array}{c}\text { Carga ao atingir } \\
\text { a resistência } \\
\text { máxima } \\
(\mathrm{N})\end{array}$ \\
\hline$\underline{\mathrm{A}-2}$ & 82,88 & 0,87 & 8,7 & 54,36 & 5200,07 \\
\hline$\underline{\mathrm{A}-3}$ & 98,38 & 1,08 & 10,8 & 91,96 & 9374,49 \\
\hline $\mathrm{B}-1$ & 114,02 & 0,97 & 9,7 & 97,98 & 7057,88 \\
\hline$\underline{\mathrm{B}-2}$ & 90,58 & 1,17 & 11,7 & 59,90 & 7050,05 \\
\hline$\underline{\mathrm{D}-2}$ & 52,98 & 0,60 & 6,0 & 52,07 & 3279,35 \\
\hline $\mathrm{D}-3$ & 109,69 & 0,95 & 9,5 & 84,52 & 7112,78 \\
\hline & 67,49 & 0,73 & 7,3 & 16,09 & 4787,03 \\
\hline
\end{tabular}

${ }^{*}$ As letras $A, B, C$ ou $D$ correspondem aos diferentes doadores e o número corresponde à identificação das diferentes amostras de cada doador.

TABELA 3 - Valores do ensaio mecânico de compressão das amostras congeladas e irradiadas com $15 \mathrm{kGy}$

\begin{tabular}{l|c|c|c|c|c}
\hline $\begin{array}{l}\text { Amostras } \\
\text { congeladas } \\
\text { irradiadas } \\
\mathbf{1 5} \text { kGy }\end{array}$ & $\begin{array}{l}\text { Resistência } \\
\text { máxima } \\
(\mathrm{MPa})\end{array}$ & \multicolumn{2}{|c|}{$\begin{array}{l}\text { Deformação à } \\
\text { resistência máxima } \\
(\mathrm{mm})\end{array}$} & $\begin{array}{c}\text { Resistência à } \\
\text { ruptura } \\
(\mathrm{MPa})\end{array}$ & $\begin{array}{c}\text { Carga ao } \\
\text { atingir a } \\
\text { resistência } \\
\text { máxima } \\
(\mathrm{N})\end{array}$ \\
\hline$\underline{\mathrm{A}-1}$ & 33,11 & 0,73 & 7,3 & 18,56 & 2642,23 \\
\hline$\underline{\mathrm{A}-3}$ & 73,59 & 1,11 & 1,1 & 70,64 & 7657,48 \\
\hline$\underline{\mathrm{B}-3}$ & 67,41 & 8,16 & 81,6 & 41,44 & 7170,30 \\
\hline$\underline{\mathrm{D}-1}$ & 96,07 & 2,50 & 25,0 & 70,36 & 7001,30 \\
\hline$\underline{\mathrm{D}-2}$ & 60,57 & 1,29 & 12,9 & 24,87 & 5382,29 \\
\hline
\end{tabular}

${ }^{*}$ As letras $A, B, C$ ou $D$ correspondem aos diferentes doadores e o número corresponde à identificação das diferentes amostras de cada doador.

TABELA 4 - Valores do ensaio mecânico de compressão das amostras liofilizadas e irradiadas com $15 \mathrm{kGy}$

\begin{tabular}{|c|c|c|c|c|c|}
\hline $\begin{array}{l}\text { Amostras } \\
\text { Liofilizadas } \\
\text { irradiadas } \\
15 \mathrm{kGy}\end{array}$ & $\begin{array}{c}\text { Resistência } \\
\text { máxima } \\
(\mathrm{MPa})\end{array}$ & $\begin{array}{r}\text { Defo } \\
\text { res } \\
\mathbf{m} \\
(\mathrm{mm}\end{array}$ & $\begin{array}{l}\text { lação à } \\
\text { ência } \\
\text { ima } \\
\\
(\%)\end{array}$ & $\begin{array}{c}\text { Resistência à } \\
\text { ruptura } \\
(\mathrm{MPa})\end{array}$ & $\begin{array}{c}\text { Carga ao } \\
\text { atingir a } \\
\text { resistência } \\
\text { máxima }\end{array}$ \\
\hline$A-2$ & 68,30 & 0,94 & 9,4 & 99,75 & 5459,47 \\
\hline$\overline{A-3}$ & 55,66 & 0,64 & 6,4 & 65,18 & 6645,32 \\
\hline$\overline{\mathrm{B}-1}$ & 56,75 & 0,90 & 9,0 & 67,70 & 6813,50 \\
\hline$\overline{B-2}$ & 29,38 & 0,68 & 6,8 & 36,64 & 2125,94 \\
\hline$\overline{B-3}$ & 40,67 & 1,23 & 12,3 & 57,91 & 3862,91 \\
\hline$\overline{\mathrm{C}-1}$ & 34,91 & 0,87 & 8,7 & 69,20 & 5172,94 \\
\hline$\overline{\mathrm{D}-1}$ & 11,18 & 0,46 & 4,6 & 49,68 & 2794,51 \\
\hline$\overline{\mathrm{D}-3}$ & 42,43 & 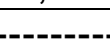 & 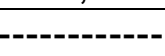 & 59,88 & 4651,77 \\
\hline
\end{tabular}

${ }^{*}$ As letras $A, B, C$ ou $D$ correspondem aos diferentes doadores e o número corresponde à identificação das diferentes amostras de cada doador. 
TABELA 5 - Valores do ensaio mecânico de compressão das amostras congeladas e irradiadas com $25 \mathrm{kGy}$

\begin{tabular}{|c|c|c|c|c|c|}
\hline $\begin{array}{l}\text { congeıauas } \\
\text { irradiadas } \\
25 \text { kGy }\end{array}$ & $\begin{array}{c}\max ı \mathbf{m a} \\
(\mathrm{MPa})\end{array}$ & \multicolumn{2}{|c|}{$\begin{array}{l}\text { resısıencıa } \\
\text { máxima }\end{array}$} & $\begin{array}{c}\text { a ruptura } \\
(\mathrm{MPa})\end{array}$ & $\begin{array}{l}\text { a resısıencıa } \\
\text { máxima } \\
(\mathrm{N})\end{array}$ \\
\hline$\underline{A-1}$ & 47,95 & 0,47 & 4,7 & 34,06 & 4355,35 \\
\hline$\underline{A-3}$ & 52,96 & 6,50 & 65,0 & 40,24 & 4492,06 \\
\hline B-1 & 105,46 & 0,94 & 9,4 & 76,75 & 9599,15 \\
\hline$\overline{\mathrm{B}-2}$ & 86,50 & 0,06 & 0,6 & 85,72 & 5602,23 \\
\hline C-2 & 75,76 & 0,64 & 6,4 & 72,58 & 4617,60 \\
\hline D-1 & 67,24 & 1,81 & 18,1 & 52,66 & 3648,50 \\
\hline D-2 & 45,53 & 1,06 & 10,6 & 41,76 & 3492,67 \\
\hline
\end{tabular}

${ }^{*}$ As letras $\mathrm{A}, \mathrm{B}, \mathrm{C}$ ou $\mathrm{D}$ correspondem aos diferentes doadores e o número corresponde à identificação das diferentes amostras de cada doador.

TABELA 6 - Valores do ensaio mecânico de compressão das amostras liofilizadas e irradiadas com $25 \mathrm{kGy}$

\begin{tabular}{l|c|c|c|c|c}
\hline $\begin{array}{c}\text { Amostras } \\
\text { Liofilizadas } \\
\text { irradiadas } \\
\text { 25 kGy }\end{array}$ & $\begin{array}{c}\text { Resistência } \\
\text { máxima } \\
(\mathrm{MPa})\end{array}$ & \multicolumn{2}{|c|}{$\begin{array}{c}\text { Deformação à } \\
\text { resistência } \\
\text { máxima } \\
(\mathrm{mm})\end{array}$} & $\begin{array}{c}\text { Resistência } \\
\text { à ruptura } \\
(\mathrm{MPa})\end{array}$ & $\begin{array}{c}\text { Carga ao atingir } \\
\text { a resistência } \\
\text { máxima } \\
(\mathrm{N})\end{array}$ \\
\hline$\underline{\mathrm{A}-2}$ & 34,76 & 0,55 & 5,5 & 39,11 & 3569,82 \\
\hline$\underline{\mathrm{A}-3}$ & 36,10 & 0,062 & 0,62 & 35,5 & 2956,66 \\
\hline$\underline{\mathrm{B}-2}$ & 58,14 & 0,84 & 8,4 & 51,37 & 4980,06 \\
\hline$\underline{\mathrm{C}-2}$ & 74,69 & 0,60 & 6,0 & 84,97 & 5519,36 \\
\hline $\mathrm{D}-1$ & 107,53 & 0,98 & 9,8 & 109,64 & 7045,96 \\
\hline
\end{tabular}

${ }^{\star}$ As letras A, B, D ou D correspondem aos diferentes doadores e o número corresponde à identificação das diferentes amostras de cada doador.

TABELA 7 - Valores do ensaio mecânico de compressão das amostras congeladas e irradiadas com $50 \mathrm{kGy}$.

\begin{tabular}{|c|c|c|c|c|c|}
\hline \multirow[t]{2}{*}{$\begin{array}{c}\text { Amostras } \\
\text { Congeladas } \\
\text { irradiadas } \\
50 \mathrm{kGy}\end{array}$} & \multirow{2}{*}{$\begin{array}{c}\begin{array}{c}\text { Resistência } \\
\text { máxima } \\
(\mathrm{MPa})\end{array} \\
109,01\end{array}$} & \multicolumn{2}{|c|}{$\begin{array}{l}\text { Deformação à } \\
\text { resistência } \\
\text { máxima } \\
(\mathrm{mm}) \quad(\%)\end{array}$} & \multirow{2}{*}{\begin{tabular}{|c|}
$\begin{array}{c}\text { Resistência } \\
\text { à ruptura } \\
\text { (MPa) }\end{array}$ \\
104,17
\end{tabular}} & \multirow{2}{*}{\begin{tabular}{|c}
$\begin{array}{c}\text { Carga ao atingir } \\
\text { a resistência } \\
\text { máxima } \\
(\mathrm{N})\end{array}$ \\
10119,47
\end{tabular}} \\
\hline & & 1,37 & 13,7 & & \\
\hline$\overline{\overline{\mathrm{A}-2}}$ & 65,97 & 0,64 & 6,4 & 41,25 & 4671,51 \\
\hline$\overline{\mathrm{A}-3}$ & 73,56 & 1,11 & 11,1 & 53,59 & 5888,15 \\
\hline B-2 & & & 144 & & \\
\hline$\overline{B-3}$ & 115,22 & 1,26 & 12,6 & 76,91 & 8645,68 \\
\hline$\overline{\mathrm{D}-1}$ & 52,65 & 0,98 & 9,8 & 31,23 & 3563,94 \\
\hline$\overline{\mathrm{D}-2}$ & 25,26 & 0,63 & 6,3 & 19,93 & 1875,48 \\
\hline
\end{tabular}

${ }^{*}$ As letras $A, B, C$ ou $D$ correspondem aos diferentes doadores e o número corresponde à identificação das diferentes amostras de cada doador. 
TABELA 8 - Valores do ensaio mecânico de compressão das amostras liofilizadas e irradiadas com 50 kGy obtidos por meio do ensaio mecânico de compressão

\begin{tabular}{|c|c|c|c|c|c|}
\hline $\begin{array}{c}\text { Amostras } \\
\text { Liofilizadas } \\
\text { irradiadas } \\
50 \mathrm{kGy}\end{array}$ & $\begin{array}{c}\text { Resistência } \\
\text { máxima } \\
(\mathrm{MPa})\end{array}$ & \multicolumn{2}{|c|}{$\begin{array}{l}\text { Deformação à } \\
\text { resistência } \\
\text { máxima } \\
(\mathrm{mm}) \quad(\%)\end{array}$} & $\begin{array}{l}\text { Resistência } \\
\text { à ruptura } \\
(\mathrm{MPa})\end{array}$ & $\begin{array}{l}\text { Carga ao atingir } \\
\text { a resistência } \\
\text { máxima } \\
(\mathrm{N})\end{array}$ \\
\hline C-1 & 105,38 & 1,33 & 13,3 & 83,77 & 7761,61 \\
\hline$\overline{\mathrm{C}-2}$ & 62,16 & 0,85 & 8,5 & 22,51 & 2269,06 \\
\hline$\overline{\mathrm{D}-3}$ & 53,75 & 0,86 & 8,6 & 53,21 & 2077,38 \\
\hline
\end{tabular}

${ }^{*}$ As letras $\mathrm{A}, \mathrm{B}, \mathrm{C}$ ou $\mathrm{D}$ correspondem aos diferentes doadores e o número corresponde à identificação das diferentes amostras de cada doador.

Na FIG. 30 observa-se o gráfico da resistência máxima (MPa) de todos os valores das diferentes doses e preservações. 


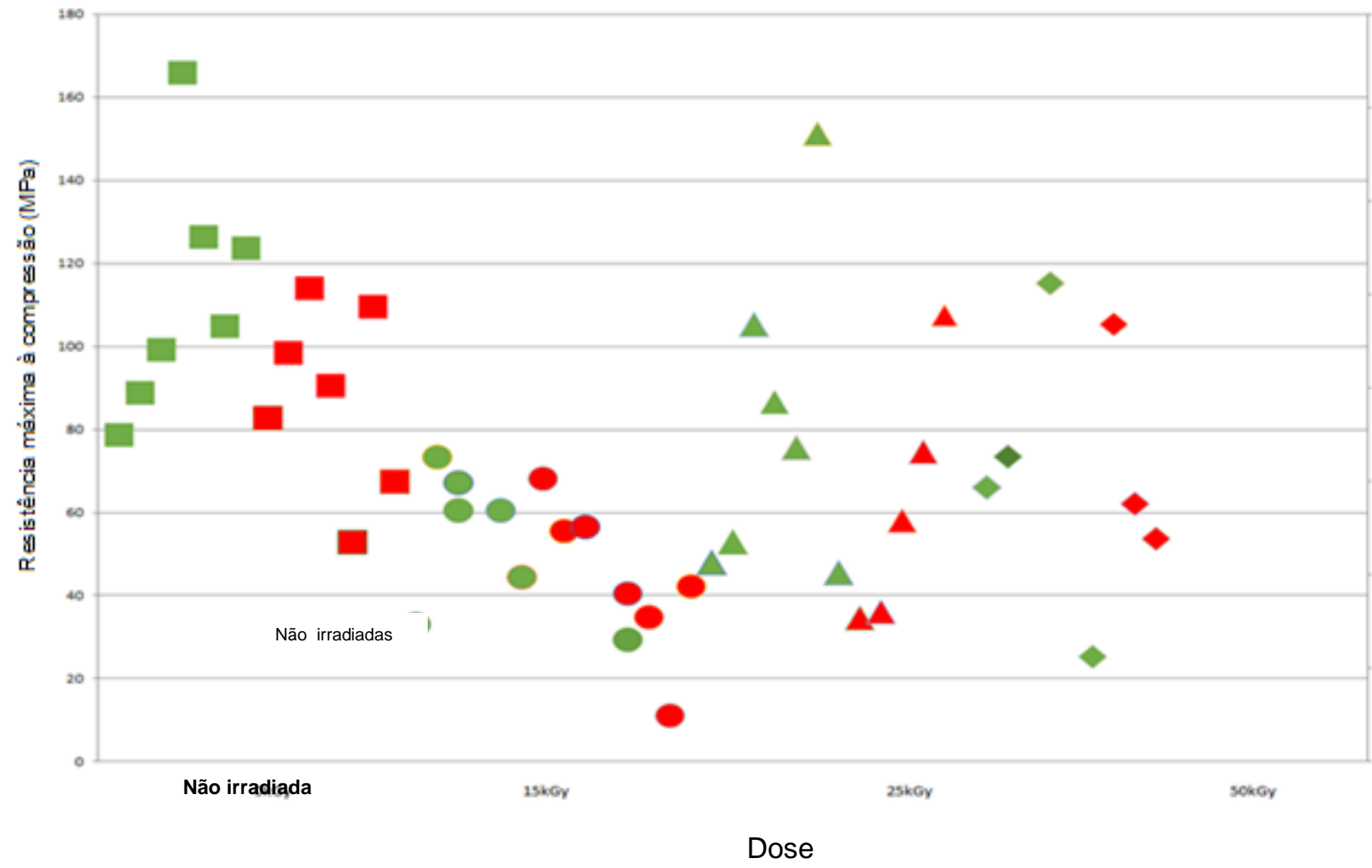

FIGURA 30 - Gráfico da resistência máxima (MPa) das amostra ósseas.( $\square$ ) amostras não irradiadas e congeladas; ( $\square$ ) amostras não irradiadas e liofilizadas; (-) amostras congeladas e irradiadas com $15 \mathrm{kGy}$; (-) amostras liofilizadas e irradiadas com $15 \mathrm{kGy}$; $(\boldsymbol{\Delta})$ amostras congeladas e

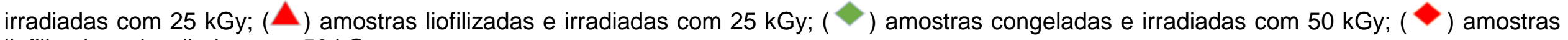
liofilizadas e irradiadas com 50 kGy. 


\section{DISCUSSÃO}

Mesmo nos dias atuais ainda existe resistência por parte de alguns cirurgiões em utilizar tecidos ósseos esterilizados por radiação ionizante, devido às possíveis alterações que podem ocorrer, como a modificação da cor. Alguns profissionais associam essa mudança estética com alterações na matriz óssea, como a diminuição da resistência mecânica devido às possíveis modificações na organização das fibras de colágeno.

Neste trabalho utilizamos a colorimetria para avaliar as modificações estéticas ocasionadas no tecido ósseo após o processamento por radiação. Nos parâmetros $a^{*}$ (quanto mais positivo, mais avermelhado e quanto mais negativo mais esverdeado) e $b^{*}$ (quanto mais positivo, mais amarelado e quanto mais negativo mais azulado), ao compararmos os controles não irradiados, observa-se que ocorreu uma diminuição das cores vermelha $\left(a^{*}\right)$ e amarela $\left(b^{*}\right)$ nas amostras liofilizadas em relação às amostras congeladas (FIG. 20 e 21). A coloração amarelada provavelmente está relacionada com resquícios de material lipídico no tecido ósseo e a coloração vermelha com a presença de tecido hematopoiético, sendo que ambos são retirados durante o processamento realizado nos Bancos de Tecidos. No entanto, com os dados obtidos percebe-se que há uma tendência do processo de liofilização contribuir com uma melhor retirada destes resquícios.

Quanto à influência da radiação ionizante nos tecidos processados, observamos uma diminuição da cor vermelha nas amostras congeladas e irradiadas nas diferentes doses ao compará-las com o controle (FIG. 20-A). Provavelmente a irradiação contribuiu para a degradação das hemácias ainda presentes no tecido ósseo.

Nas doses de $50 \mathrm{kGy}$ tanto para as amostras liofilizadas quanto para as congeladas ocorreu um aumento da coloração amarelada $\left(b^{*}\right)$, mas este dado está mais relacionado com os efeitos radiação, ou seja, as doses altas tendem a acarretar uma mudança na coloração do material (FIG.21).

Nas amostras liofilizadas, o parâmetro de luminosidade $\left(\mathrm{L}^{*}\right)$ não apresentou alteração em relação às amostras congeladas, nem em relação às amostras irradiadas, observando-se apenas uma ligeira tendência de diminuição deste parâmetro nas amostras liofilizadas e irradiadas com 50 kGy (FIG.22), corroborando com os dados do eixo $\mathrm{b}^{*}$, onde doses altas de irradiação acarretam uma alteração na coloração da amostra. 
$\mathrm{Na}$ literatura não existem trabalhos que avaliam as modificações de cor, em tecido ósseo, após o processamento por radiação. Existem várias hipóteses para explicar as causas da alteração de cor, mas para o presente estudo o fator importante é avaliar se essas alterações podem representar possíveis modificações da matriz óssea.

Para investigar se a modificação de cor está relacionada com alterações na matriz óssea, utilizamos as técnicas de OCT, PS-OCT, espectroscopia Raman e ensaio mecânico de compressão.

Primeiramente, utilizamos a técnica de OCT (FIG. 9) para avaliar as possíveis modificações morfológicas no tecido ósseo.

Por meio apenas da imagem de OCT (FIG.16) não é possível identificar as modificações estruturais, uma vez que as imagens geradas são construídas por meio de valores do sinal de retroespalhamento dos fótons no tecido, a partir deste sinal podemos calcular o coeficiente de atenuação óptica total e, dessa forma, realizar uma comparação quantitativa entre os diferentes grupos.

Em 2013, Martinho Junior, utilizou o cálculo do coeficiente de atenuação óptica total para avaliar os efeitos da preservação e radioesterilização em cartilagem humana e verificou que esta grandeza pode ser utilizada para prognosticar a qualidade mecânica do tecido, pois essa grandeza é diretamente proporcional à tensão de ruptura do mesmo.

Nas amostras ósseas, observa-se uma tendência na diminuição do coeficiente de atenuação óptica total do controle não irradiado das amostras liofilizadas em relação ao controle não irradiado das amostras congeladas, revelando que a forma de preservação pode induzir a efeitos mais deletérios na matriz óssea que a própria irradiação (conforme FIG. 25).

Este dado amplifica o estudo realizado por Komender, que em 1976 demonstrou que os ossos preservados por liofilização diminuem em $35 \%$ a resistência à flexão quando comparados aos ossos frescos (não preservado e não irradiado).

Em outros estudos realizados por nosso grupo, como o de Martinho Junior (2012), que analisou o comportamento mecânico e termogravimétrico das cartilagens humanas preservadas por congelamento e preservadas em glicerol, constatou-se que a forma de preservação por congelamento acarreta menores 
alterações na resistência mecânica de cartilagens irradiadas, quando comparadas à preservação com altas concentrações de glicerol.

Nas amostras ósseas liofilizadas, a dose de 25 kGy apresentou uma diminuição significativa em relação ao controle e essa alteração pode estar relacionada com a modificação na estrutura de tripla hélice do colágeno ou na organização geral das fibras, verificando-se que a liofilização, além de alterar por si só o valor do coeficiente de atenuação, também torna o material mais suscetível aos efeitos diretos da radiação ionizante.

Para constatar se estas alterações ocorrem na organização das fibras de colágeno foi necessária a utilização da técnica de PS-OCT, já que esta tecnologia avalia a propriedade de birrefringência presente no direcionamento do colágeno (FIGURAS 26 e 27). Com os dados obtidos, notamos que a propriedade de birrefringência foi mantida após a preservação e irradiação nas diferentes doses, ou seja, as fibras paralelas não perderam a sua organização. No entanto, os resultados obtidos por esta técnica não foram utilizados para quantificar tais alterações e será necessário o desenvolvimento de um programa para uma anáise mais aprofundada.

Em 2005, Xingde et al., utilizou a técnica de PS-OCT para detectar alterações na organização das fibras de colágeno de cartilagem proveniente de osteoartrite e o mesmo autor constatou uma desorganização da rede de colágeno nas regiões afetadas do tecido. A partir destes dados, pode-se inferir que a técnica é sensível para avaliar as alterações nos tecidos biológicos.

No entanto, as modificações detectadas pelo OCT ainda podem estar relacionadas com modificações na estrutura terciária do colágeno, mesmo não alterando sua organização.

A espectroscopia Raman nos auxiliou a indagar tais alterações a nível molecular (conforme item 3.6.5), já que esta técnica investiga os níveis energéticos ligados aos movimentos vibracionais dos núcleos dos átomos constituintes das moléculas (Arêas \& Kawano, 1991). A maioria das bandas de um espectro de osso corresponde ao fosfato mineral, carbonato e a matriz óssea (conforme FIG. 10). O pico de maior intensidade está centrado em $959 \mathrm{~cm}^{-1}$ que corresponde à vibração de alongamento simétrico do fosfato, o qual representa o principal marcador do conteúdo mineral ósseo (Morris \& Mandair, 2011). Os modelos vibracionais 
relacionados à matriz orgânica correspondem a amida I e amida III, esses compostos orgânicos estão presentes nos aminoácidos glicina e prolina, que são componentes primários da proteína do colágeno (Chang \& Tanaka, 2002). Conforme o item (3.5.4.4) a área da banda do fosfato dividida pela área da banda da amida I, obtém-se a razão mineral-matriz, essa razão indica o grau de mineralização da matriz óssea.

Os resultados obtidos pela técnica de espectroscopia Raman demonstrou uma correlação com os resultados encontrados com a técnica de OCT, pois para as amostras liofilizadas e irradiadas na dose de 25 kGy (FIG. 28-B), ocorreu uma diminuição do coeficiente de atenuação óptica total dos fótons e também uma redução da proporção mineral/matriz. Observa-se também uma diminuição da proporção mineral/matriz nas amostras liofilizadas não irradiadas em comparação com as amostras congeladas não irradiadas (FIG. 29).

Ao compararmos os resultados de ambas as técnicas, observamos que provavelmente essa diminuição razão mineral/matriz está relacionada com as modificações na estrutura terciária do colágeno, já que outros autores como Wright (1981) detectaram que os efeitos da radiação estão relacionados com modificações nas cadeias de colágeno e sua interação com a fase mineral.

Um estudo realizado por Yamamoto et al. (2012) também encontrou uma discreta diminuição da relação fosfato/amida I em amostras irradiadas com a dose de 25 kGy quando comparada ao controle (não irradiado e não preservado).

Segundo Akkus et al. (2004), o aumento da razão mineral/matriz foi correlacionado com a deterioração estrutural e mecânica do tecido ósseo. Para investigar se o aumento da proporção mineral/matriz, nas amostras liofilizadas nas doses de 15 e 50 kGy, ocasionou uma diminuição da resistência, o ensaio mecânico foi essencial.

Diversos fatores podem afetar os resultados dos ensaios mecânicos, como a idade e sexo dos doadores, tamanho das amostras, posição anatômica durante o teste e principalmente a direção e o tipo de ensaio mecânico (Zioupos, 2000).

Devido a esses fatores citados acima não foi adequado calcular os valores médios da resistência máxima dos ensaios mecânicos de compressão e não foi realizada a média e o desvio padrão dos resultados obtidos por este ensaio, já que os doadores tem características diferentes, como visto no Quadro 2. 
Outro fator é que neste trabalho foi utilizada a fíbula humana, que apresenta um formato bastante irregular e que originou amostras bastante heterogêneas que interferem nos resultados do ensaio mecânico. Portanto, algumas amostras foram excluídas, pois apresentaram um formato distinto das outras ou alguma outra limitação, como a presença significativa de tecido ósseo esponjoso.

No teste de compressão, conforme TABELAS 1 e 2 e FIG. 30, apesar de observarmos uma grande variação de resulados nas amostras controle congeladas (aproximadamente $20 \%$ ), pode-se notar os resultados das amostras controle liofilizadas, sofreram uma maior variação (40\%), além de uma pequena tendência a diminuir a resistência máxima a compressão.

As amostras congeladas e liofilizadas, irradiadas na dose de $15 \mathrm{kGy}$ apresentaram uma tendência a resistência máxima à compressão inferior as amostras não irradiadas (TABELAS 1 ao 4 e FIG. 30). As amostras irradiadas na dose de $25 \mathrm{kGy}$ em ambas as formas de preservação também apresentaram uma diminuição (TABELAS 5 e 6), em relação ao controle, não tão evidente quanto as amostras irradiadas com $15 \mathrm{kGy}$.

Esse dado também foi visto por Russell, 2012 que notou uma diminuição no estresse axial final de 6\% para as amostras irradiadas com $15 \mathrm{kGy}$ e de $16 \%$ nas irradiadas com $25 \mathrm{kGy}$.

Para as amostras congeladas irradiadas na dose de $50 \mathrm{kGy}$ em ambas as formas de preservação (TABELAS 7 e 8) foi evidenciado uma diminuição na resistência a compressão máxima e para as amostras liofilizadas, assim como observado no seu respectivo controle, os dados não foram conclusivos, pois os resultados apresentaram uma variação elevada $(27 \%)$, além de diversas amostras terem sido descartadas devido aos critérios de exclusão, resultando em um $n=3$.

A diminuição da resistência máxima a compressão na dose de 15 kGy corrobora os dados encontrados na razão mineral/matriz, utilizando a técnica de espectroscopia Raman, como postulado por Akkus et al. (2004).

Com relação à dose, Akkus e Rimnac (2001) encontraram uma significativa diminuição da resistência à fratura em testes de tensão e compressão para amostras congeladas e irradiadas com a dose $27.5 \mathrm{kGy}$ quando comparadas ao controle. Em 2004, Mitchell constatou que ossos irradiados com 31.7 kGy são significativamente menos resistentes ao crescimento das fissuras ocasionadas por 
fadiga do que os ossos não irradiados. Nas nossas condições, também encontramos uma significativa diminuição à resistência à fratura nas doses de 25 kGy, apesar de não tão pronunciada quanto para as doses de 15 kGy (dose não avaliada por esses autores).

Nos testes de espectroscopia Raman e OCT foi observado que a dose de 25 kGy para as amostras liofilizadas ocorreu uma diminuição no coeficiente de atenuação óptica total dos fótons como também para a proporção mineral/matriz. Este dado pode estar relacionado a uma possível modificação na estrutura triplahélice do colágeno que consequentemente modificou a atenuação óptica total dos fótons.

Segundo Cara (2012) que utilizou a técnica de OCT para detectar os graus de desmineralização do esmalte dental durante o desenvolvimento de lesões simuladas de cárie, o coeficiente de atenuação óptica total dos fótons aumenta quando se criam espaços vazios na estrutura do esmalte dental após o processo de desmineralização, aumentando o número de interfaces e consequentemente aumentando o espalhamento da luz.

Provavelmente pode ter ocorrido, na dose de 25 kGy, uma constrição da estrutura tripla hélice do colágeno diminuindo os espaços vazios e consequentemente reduzindo o coeficiente de atenuação óptica total, e segundo Martinho Jr. (2012) ocorre a formação de ligações cruzadas das fibrilas colágenas contribuindo para o preenchimento dos espaços entre as mesmas, diminuindo a reflexão da luz por esta encontrar menos interfaces, resultando num menor coeficiente de atenuação.

Por meio deste trabalho, vimos que as alterações ocorridas pela radiação ionizante estão relacionadas com a forma de preservação, pois a liofilização deixa o tecido mais suscetível às alterações ocasionadas pela esterilização por raios gama, já que todas as diferenças estatisticamente significativas foram evidenciadas em amostras ósseas liofilizadas, onde ocorreram os efeitos diretos da radiação. Em ambas as formas de preservação, as amostras irradiadas com 15 kGy não obtiveram uma modificação na estrutura do colágeno, mas no entanto se tornaram menos resistentes, já com a dose de 25 kGy, para as amostras liofilizadas, ocorreu uma modificação na matriz orgânica quando comparada ao controle. 
Cabe aos Bancos de Tecidos selecionar a dose a partir de uma contaminação inicial e a preservação do tecido ósseo a ser irradiado, levando em consideração que estes procedimentos não acarretem modificações drásticas ao material, que possam gerar o insucesso do aloenxerto. 


\section{CONCLUSÃo}

Observou-se que as modificações nas cores iniciais estão mais relacionadas ao processamento e preservação das amostras, sendo que nas amostras irradiadas somente foi observado um aumento da coloração amarelada na dose de 50 kGy. A forma de preservação por liofilização ocasionou maiores modificações na estrutura terciária do colágeno dos ossos irradiados nas diferentes doses, principalmente nas doses acima de $25 \mathrm{kGy}$, porém estas modificações não foram suficientes para alterar a organização das fibras deste colágeno.

A dose de 15 kGy ocasionou uma diminuição da resistência mecânica em ambas as formas de preservação e nesta dose também foi evidenciado um aumento da razão mineral/matriz.

As alterações ocasionadas na dose de 15 kGy parecem ser reversíveis, levando em consideração que as mesmas não foram detectadas após irradiação do tecido ósseo com doses de 25 e 50 kGy, porém outros estudos utilizando técnicas complementares serão necessários para melhor entendimento deste fenômeno. 


\section{8. REFERÊNCIAS BIBLIOGRÁFICAS}

AKKUS, O.; ADAR, F.; SCHAFFLER, M.B. Age-related changes in physicochemical properties of mineral crystals are related to impaired mechanical function of cortical bone. Bone. v. 34, n.3, p. 443-453, 2004.

AKKUS, O.; RIMNAC, C.M. Fracture resistance of gamma radiation sterilized cortical bone allografts. Journal of Orthopaedic Research. v. 19, p.927-934, 2001.

ALBERTS, B.; BRAY, D.; LEWIS, J., RAFF, M.; ROBERTS, K.; WATSON, J.D. Biologia molecular da célula. 5.ed., 2002.

AMATUZZI, M.M.; CROCI, A.T.; GIOVANI, A.M.M.; SANTOS, L.A.U. Banco de tecidos: estruturação e normatização. Revista Brasileira de Ortopedia, v.35, n. 5, p. 165-172, 2000.

ARÊAS, E.P.G., KAWANO, Y. Aplicações de técnicas espectroscópicas vibracionais ao estudo conformacional de proteínas. Química Nova. v.14, n.1, p. 31-43, 1991.

BAPTISTA, A.D.; SORRILHA, A.; TORMES, T.A.M.; ABDOUNE, Y.A.; CAMARGO, O.P.; OLIVEIRA, C.R.G.C.M. Estudo Histológico dos Enxertos Ósseos Homólogos Humanos. Acta ortopedia brasileira. v.11, n.4,p-220-224, 2003

BRASIL, Lei $n^{\circ}$ 9434, de 04 de fevereiro de 1997. Dispõe sobre a remoção de órgãos, tecidos e partes do corpo humano para fins de transplante e tratamento e da outras providencias. D.O.U. - Diário Oficial da União; Poder Executivo, de 05 de fevereiro de $1997 . \quad$ Disponível em: http://www.planalto.gov.br/ccivil 03/leis/19434.htm Acesso em: 28/05/2013.

BRASIL, Lei n 10211, de 23 de março de 2001. Altera dispositivos da Lei no 9.434, de 4 de fevereiro de 1997, que "dispoe sobre a remocao de orgaos, tecidos e partes do corpo humano para fins de transplante e tratamento". D.O.U. - Diario Oficial da Uniao; Poder Executivo, de 24 de marco de 2001. Disponivel em: http://www.planalto.gov.br/ccivil 03/leis/leis 2001/l10211.htm Acesso em: 28/05/2013.

BRASIL, Portaria $n^{\circ} 2.600$, de 21 de outubro de 2009. Aprova o Regulamento Tecnico do Sistema nacional de transplantes. Disponível em: 
http://bvsms.saude.gov.br/bvs/saudelegis/gm/2009/prt2600 2110 2009.html>. Acesso em: 28/05/2013

BREZINSKI, M.E. Optical coherence tomography for identifying unstable coronary plaque.International Journal of Cardiology. v. 107, p.154-165, 2006.

BREZINSKI, M.E.; TEARNEY G.J.; BOUMA B.E.; BOPPART S.A.; HEE, M.R.; SWANSON, E.A.; SOUTHERN, J.F.; FUJIMOTO, J.G: Imaging of coronary artery microstructure (in vitro) with optical coherence tomography. American Journal of Cardiology. v.77, p. 92-93,1996.

BUDENZ, D.L.; ANDERSON, D.R.; VARMA, R.; SCHUMAN, J.; CANTOR, L.; SAVELL, J.; GREENFIELD, D.S.; PATELLA, V.M.; QUIGLEY, H.A.; TIELSCH, J. Determinants of normal retinal nerve fiber layer thickness measured by stratus OCT. Ophthalmology. v. 114, n.6, p. 1046-1052, 2007.

CALLISTER, W. D. Jr. Ciência e engenharia de materiais uma introdução, São Paulo, LTC, 7 ed., 2008. p. 100-102.

CALVO, W.A.P. Desenvolvimento do Sistema de Irradiação em um Irradiador Multipropósito de Cobalto-60 tipo Compacto. Tese. Instituto de Pesquisas Energéticas e Nucleares - USP. São Paulo. 2005.

CARA, A.C.B. Avaliação do processo de desenvolvimento de desmineralização em esmalte dental humano utilizando a técnica de tomografia por coerência óptica. 2012.Dissertação de Mestrado. Universidade de São Paulo, São Paulo.

CHANG, M.C.; TANAKA, J. FT-IR study for hydroxyapatite/collagen nanocomposite cross-linked by glutaraldehyde. Biomaterials, v.23, n.24, p. 4811-4818, 2002.

CONWAY, B.; TOMFORD, W.W. Radiosensitivity of Human Immunodeficiency Virus Type 1. Clinical infectious diseases.v.14, n.4, p. 978-979, 1992.

DAHLAN, K. Z. H. M. Radiation Sciences. In: PHILLIPS, G. O. , NATHER, A. Advances in tissue banking $v$. 5 . The Scientific Basis of Tissue Transplantation. Singapura: World Scientific, 2001.

DE BOER, J. F.; MILNER, T. E.; VANGEMERT, M. J. C.; NELSON, J. S. Twodimensional birefringence imaging in biological tissue by polarization-sensitive optical coherence tomography, Optics Letters. v.22, n.12, p.934-936, 1997. 
DEL VALLE, R. A.; CARVALHO, M.L.; GONZALEZ, M.R. Estudo do comportamento de enxerto ósseo com material doador obtido dos bancos de tecidos músculo - esqueléticos. Revista de Odontologia da Universidade de São Paulo . São Paulo, v. 18, n. 2, p. 189-194, 2006.

DRESSELHAUS, A., M.S.; DRESSELHAUSB, G.; SAITOC, R.; JORIOD, A. Raman spectroscopy of carbon nanotubes. Physics Reports. v.409, p. 47-99, 2005.

DROBNY, J.G. lonizing Radiation and Polymers: Principles, Technology, and Applications. 1 ed. Estados Unidos. Elsevier, 2012.

DZIEDZIC-GOCLAWSKA, A.; KAMINSKI, A.; UHRYNOWSKA-TYSZKIEWICZ, I.;STACHOWICZ, W. Irradiation as a safety procedure in tissue banking. Cell and Tissue Banking, v. 6, p.201-219, 2005.

DZIEDZIC-GOCLAWSKA, A. The application of ionising radiation to steriliseconnective tissue allografts. In: PHILLIPS, G. O. Radiation and Tissue Banking,World Scientific, 2000.

FEOFILOFF, E. T.; JESUS-GARCIA, R. Técnicas de obtenção, processamento, armazenamento e utilização de homoenxertos ósseos. Revista Brasileira de Ortopedia. v. 31, n. 11, 1996.

FIDELER, B.M.; VANGSNESS, JR, C.T.; MOORE, T.; LI Z.; RASHEED, S. Effect of gamma radiation on the human immunodeficiency virus. A study in frozen human bone-patellar ligament-bone grafts obtained from infected cadavera. The Journal of Bone \& Joint Surgery. v. 76, p. 1032-1035, 1994.

FREITAS, A. Z.; AMARAL, M. M.; RAELE, M. P. Optical Coherence Tomography:Development and Applications. In: Duarte, F. J. Laser Pulse Phenomena and Applications, inTech, Croácia, p. 409-432, 2010.

FREITAS, A.Z.; VIEIRA, JR, N.D.; RIBEIRO, A.C.; GOMES, A.S.L. Imaging carious human dental tissue with optical coherence tomography. Journal of Applied Physics, v.99, n.2, p. 024906, 2006.

FRIEDLANDER, G.E. - Bone banking and clinical applications. Transplant. Proc., v.17, p. 99-104, 1985. 
FUJIMOTO, J. G.; BREZINSKI, M. E.; TEARNEY, G. J.; BOPPART, S., A.; BOUMA, B.; HEE, M. R.; SOUTHERN J. F.; SWANSON, E. A. Optical biopsy and imaging using optical coherence tomography. Nature Medicine, v.1, p.970-972, 1995.

FUJIMOTO, J.G. Optical coherence tomography for ultrahigh resolution in vivo imaging. Nature Biotechnology, v. $\square 21$, p.1361-1367, 2003.

HAMMER, A.J.; STOCKLEY, I.; ELSON, R. A. Changes in allograft bone irradiated at different temperatures. The Journal of Bone and Joint Surgery, v. 81, p. 342344, 1999.

HERSON, M.R.; MATHOR, M.B. Banco de Tecidos. In: GARCIA, V.D.; ABUD, M.; NEUMANN, J.; PESTANA, J.O.M. Transplantes de Órgãos e Tecidos, 2. ed. São Paulo: Segmento Farma, Cap. 16, p.174-185, 2006.

IAEA. Radiation Sterilization of Tissue Allografts: Requirements for Validation and Routine Control. A Code of Practice. Viena, Austria, 2007. Disponível em: http://www-pub.iaea.org/books/iaeabooks/7657/Radiation-Sterilization-of-issueAllografts-Requirements-for-Validation-and-Routine-Control-A-Code-of-Practice. Acesso em 20 de maio de 2013.

HEE, M. R.; HUANG, D.; SWANSON, E. A.; FUJIMOTO, J. G. PolarizationSensitive Low-Coherence Reflectometer for Birefringence Characterization and Ranging. Journal of the Optical Society of America B-Optical Physics. v.9, n.6, p.903-908,1992.

HUANG, D.; SWANSON, E. A.; LIN, C. P.; SCHUMAN, J. S.; STINSON, W. G.; CHANG, W.; HEE, M. R.; FLOTE, T.; GREGORY, K.; PULIAFITO, C.A. Optical coherence tomography, Science, v. 254, p.1178-1181, 1991.

INZANA, J.A.; MAHER, J.R.; TAKAHATA, M.; SCHWARZ, E.M.; BERGER, A.J.; AWAD, H.A. Bone fragility beyond strength and mineral density: Raman spectroscopy predicts femoral fracture toughness in a murine model of rheumatoid arthritis. Jounal Biomechanics. v.46, p.723-730, 2013.

ISO 11.137-2:2006. Sterilization of health care products - Radiation - Part 2: Establishing the sterilization dose. Disponivel em: <http://www.iso.org >. Acesso em 10 de maio de 2010. 
JACOBS J. W.; MATCHER S. J. Polarization sensitive optical coherence tomography in equine bone. Optics in Bone Biology and Diagnostics. v. 7166, p.1-10, 2009.

JUNQUEIRA, L. C.; CARNEIRO, J. Histologia Básica. 10. ed. São Paulo: Guanabara Koogan, 2004.

KAMINSKI, A.; GRAZKA, E.,; JASTRZEBSKA, A.; MAROWSKA, J.; GUT, G.; WOJCIECHOWSKI, A.; UHRYNOWSKA-TYSZKIEWICZ, I. Effect of accelerated electron beam on mechanical properties of human cortical bone: influence of different processing methods. Cell and Tissue Banking, v. 13, n.3, p. 375-386, 2012.

KIERSZENBAUM, A.L.; TRES, L.L. Histologia e Biologia Celular: uma introdução à patologia. 3.ed. Elsevier, 2012.

KOMENDER, A. Influence of preservation on some mechanical properties of human haversian bone. Mater Med Pol.v.8, p. 13-17, 1976.

LEVANDOWSKI JR., N.; PFEIFER, A.B.; PAZA, A.O.; VALIATI, R.; SILVA, M.R.P.B. Utilização do osso alógeno em bloco para aumento de rebordo alveolar: revisão da literatura. Revista implante News, 2008, v.5, n.1, p.51-57.

LUCHSINGER, B. P.; JUDA, G. A. Validation of a Thermogravimetric Method for Residual Moisture Determination in Bone Allografts. Bacterin International, Belgrade, MT. 2008. Disponível em: http://www.aatb.org/files/s1508annual.pdf

MACEDO, C.A.S. Comparação da resistência à compressão do osso bovino congelado e liofilizado. Revista Brasileira de Ortopedia e Traumatologia, v.34 , n.9, p. 529-534, 1999.

MAMEDE, L.C.; CAETANO, B.L.; ROCHA, L.A.; FERREIRA, E.M.; CESTARI, A.; KFURI, C.R.; CIUFFI, K.J.; CALEFI, P.S.; MELLO, C.; CUNHA, W.R.; NASSAR, E.J. Comportamento térmico de alguns fármacos e medicamentos. Revista de Ciências Farmacêuticas Básica e Aplicada. v.27, n.2, p.151-155, 2006.

MARCHETTI, P.; CALHEIROS, R.; CHARRO, M. Biomecânica aplicada: uma abordagem para treinamento de força. São paulo. Phorte editora. 2012.

MARTINHO JUNIOR, A.C. Estudo dos efeitos da radiacao ionizante em cartilagem costal humana por meio de Termogravimetria e Tomografia por 
Coerencia Optica. 2012. Tese de doutorado. Instituto de Pesquisas Energéticas e Nucleares, São Paulo, SP.

MARTINHO JUNIOR, A.C.; FREITAS, A.Z.; RAELE, M.P.; SANTIN, S.P.; SOARES, F.A.N.; HERSON, M.R.; MATHOR, M.B. Dependence of optical attenuation coefficient and mechanical tension of irradiated human cartilage measured by optical coherence tomography. Cell Tissue Banking,v.26, 2013.

MARTINHO JUNIOR, A. C.; MATHOR, M. B.; PINO, E. S.; SANTIN, S. P.; HERSON, M. R.; MACHADO, L. D. B.; ROSIFINI ALVES-CLARO, A. P. Effects of ionizing radiation and preservation on biomechanical properties of human costal cartilage. Cell and Tissue Banking, v. 17, p. 1-10, 2012.

MEER, F.J.V.; FABER, D.J.; AALDERS, M.C.G.; POOT, A.A.; LEEUWEN, T.G. Apoptosis- and necrosis-induced changes in light attenuation measured by optical coherence tomography. Lasers in Medical Science, v.25, n.2, p. 259-267, 2010.

MORRIS, M.D.; MANDAIR, G.S. Raman assessment of bone quality. Clinical orthopaedics and related research, v. 469, n. 8, p. 2160-2169, 2011.

NGUYEN, H.; MORGAN, D.A.F.; FORWOOD, M.R. Sterilization of allograft bone: effects of gamma irradiation on allograft biology and biomechanics. Cell and Tissue Banking. v.8, n.2, p. 93-105, 2007.

NORDIN, M.; FRANKEL, V.H. Biomecânica Básica do Sistema Musculoesquelético. 3. ed. Rio de Janeiro, Guanabara Koogan, 2001.

NGUYEN, H.; MORGAN, D.A.F.; FORWOOD, M.R. Validation of $11 \mathrm{kGy}$ as a Radiation Sterilization Dose for Frozen Bone Allografts. Cell and Tissue Banking. v.26, n. 2, p.303-308, 2011.

POPESCU, D.P.; SOWA, M. G.; HEWKO, M. D.; CHOO-SMITH, L. P. Assessment of early demineralization in teeth using the signal attenuation in optical coherence tomography images. Journal Biomedical. Optics., v.13, n.3, 054053, 2008.

PRASAD, P. N. Introduction to biophonics. John Wiley Professio, 1 ed., p. 624, 2003.

RAELE, M. P. Desenvolvimento de um Sistema de Tomografia por Coerência Óptica no domínio de Fourier sensível a polarização e sua utilização na 
determinação das matrizes de Mueller. Dissertação de Mestrado. Universidade de Sao Paulo, Sao Paulo, 2009.

REICHERT, L.A.; SPEROTTO, V.; BARBOSA, A.N.; RESTON, E.G. Estudo comparative in vitro da eficácia de clareadores para uso em moldeiras e em consultório. Stomatos. v.16, n.31, p. 14-22, 2010.

REST, M.V.; GARRONE, R. Collagen family of proteins. FASEB Journal. v.5, p. 2814-2823, 1991.

ROSS, M.H.; PAWLINA, W. Histologia - Texto e Atlas. 5 ed. Rio de Janeiro, Guanabara Koogan, 2008.

ROOS, M.V.; CAMISA JR. A.; MICHELIN, A. F. Procedimentos de um banco de ossos e a aplicabilidade dos enxertos por ele proporcionados. Acta Ortopédica Brasileira.v.8, n.3, p. 122-127, 2000.

RUSSELL, N.A.; PELLETIER, M.H.; BRUCE, W.J.; WALSH, W.R. The effect of gamma irradiation on the anisotropy of bovine cortical bone. Med Eng Phys. v.34, n.2, p. 1117-1122, 2012.

SANTOS, F.C.; RAHAL, S.C. Enxerto ósseo esponjoso autólogo em pequenos animais. Ciência Rural. v.34, n.6, p.1969-1975, 2004.

SILVA, J.H.; FREIRE, P.T.C.; ABAGARO, B.T.O.; SILVA, J.A.F.; SARAIVA,G.D.; LIMA, F.J.; DE, BARROS, O.A.; BANTIM, R.A.; SARAIVA, A.A.F.; VIANA, B.C. Spectroscopic studies of wood fossils from the Crato Formation, Cretaceous Period. Spectrochimica Acta Part A: Molecular and Biomolecular Spectroscopy. v.115, p. 324-329, 2013.

SOARES, Fernando Augusto Neves. Análise morfológica e biomecânica do âmnio conservado em glicerol esterilizado com diferentes doses de radiação ionizante. 2013. Dissertação de mestrado. Universidade de São Paulo.

SOUZA, J. de; FILHO, J.; BARROS, M., LIRA, B. Análise colorimétrica de rochas ornamentais. Estudos geológicos. v.18, n.1, p.55-64, 2008.

TRIANTAFYLLOU, N.; SOTIORPOULOS, E.; TRIANTAFYLLOU, J. The mechanical properties of lyophilised and irradiation bone grafts. Acta Orthopaedica Belgica. v.41, p. 35-44, 1975. 
VANGSNESS JR, C.T.; GARCIA, I.A.; MILLS, C.R.; KAINER, M.A.; ROBERTS, M.R. and MOORE, T.M. Allograft Transplantation in the Knee: Tissue Regulation, Procurement, Processing, and Sterilization. The American Jounal of Sports Medicine, v.31, n.3, p. 474-481, 2003.

VASTEL, L.; MEUNIER, A.; SINEY, H.; SEDEL, L.; COURPIED, J.P. Effect of different sterilization processing methods on the mechanical properties of human cancellous bone allografts. Biomaterials, v. 25, p. 2105-2110, 2004.

VIGUET-CARRIN, S.; GARNERO, P.; DELMAS, P.D. The role of collagen in bone strength. Osteoporosis International.v. 17, n.3, p. 319-336, 2006.

XINGDE, L.; MARTIN, S.; PITRIS, C.; GHANTA, R.; STAMPER, D. L.; HARMAN, M.; FUJIMOTO, J. G.; BREZINSKI, M. High-resolution optical coherence tomography imaging of osteoarthritic cartilage during open knee surgery. Arthritis Research and Therapy, v. 7, n.2, p. 381-323, 2005.

YAMAMOTO, T.; UCHIDA, K.; NARUSE, K.; SUTO, M.; URABE, K.; UCHIVAMA, K.; SUTO, K.; MORIVA, M.; ITOMAN, M.; TAKASO, M. Quality assessment for processed and sterilized bone using Raman spectroscopy. Cell Tissue Bank, v.13, n.3, p.409-414, 2012.

ZIOUPOS, P.; CURREY, J.D. Changes in the stiffness, strength, and toughness of human cortical bone with age. Bone.v.1, n.22, p. 57-66, 1998.

WRIGHT, T.M.; VOSBURGH, F.; BURSTEIN, A.H. Permanent deformation of compact bone monitored by acoustic emission. Journal of Biomechanics. v. 14, n.6, p.405-409,1981. 
APÊNDICE 1 - Imagens das amostras congeladas obtidas em diferentes posições (1-3) por Tomografia por Coerência Óptica sensível à polarização

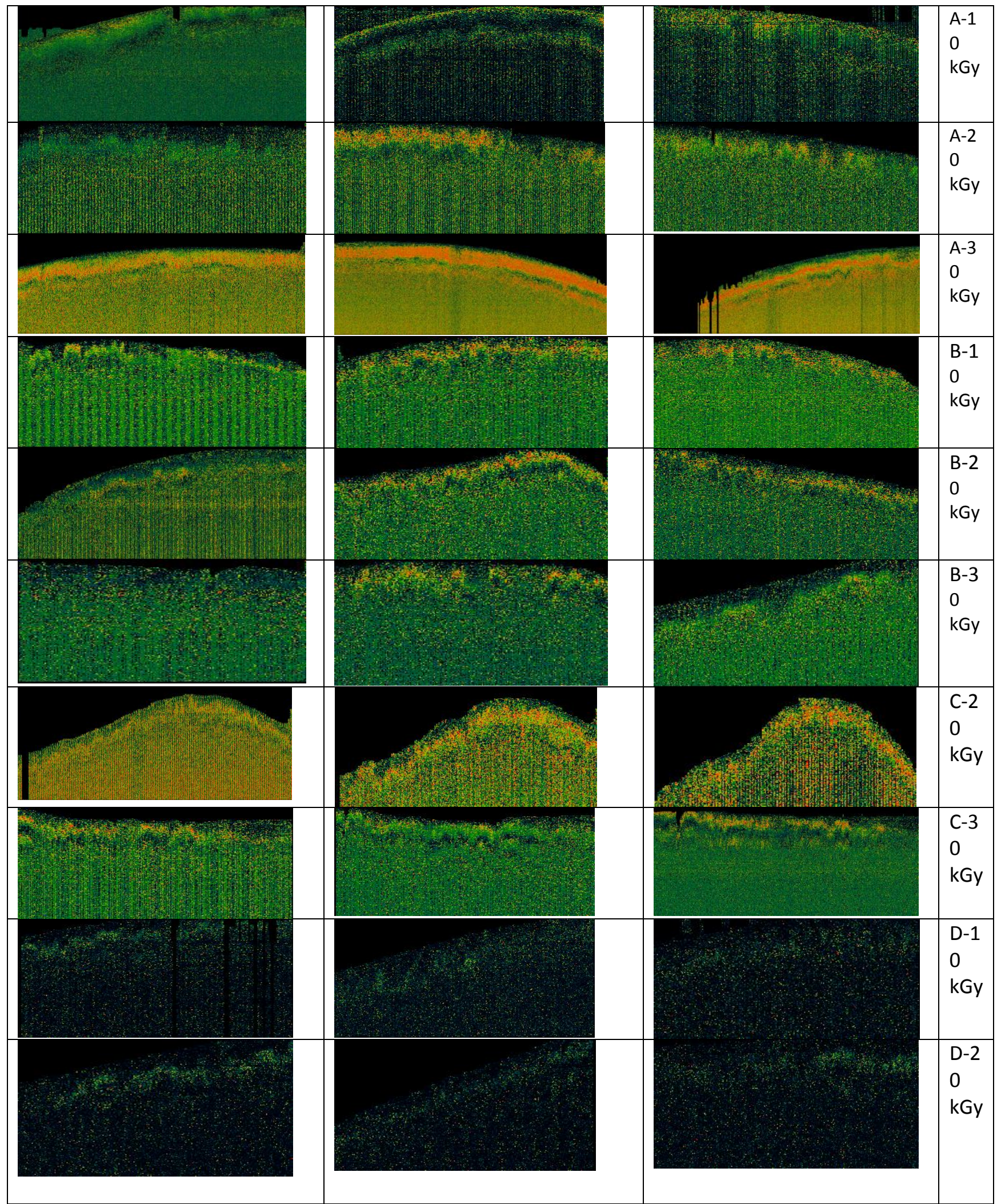




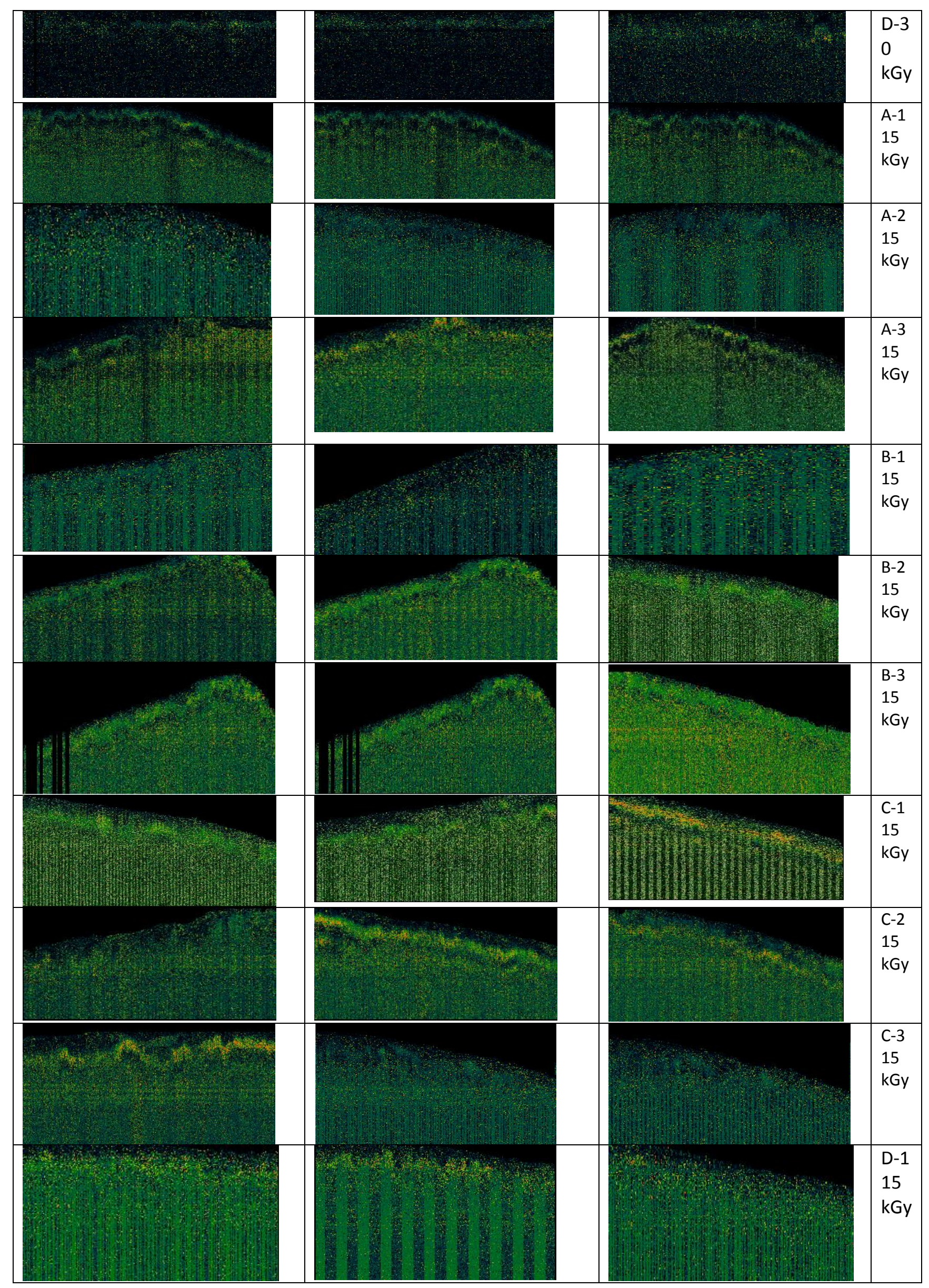




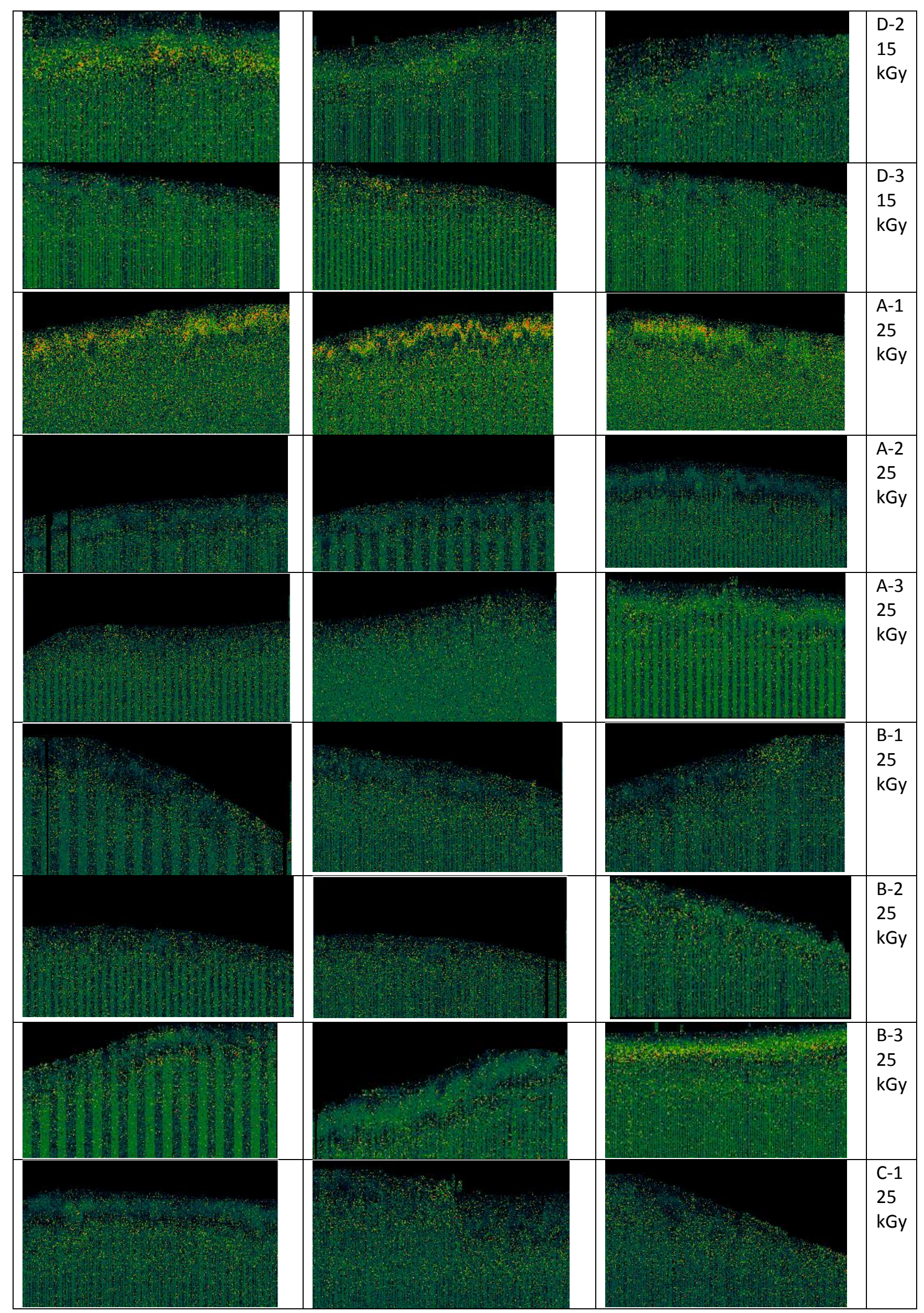




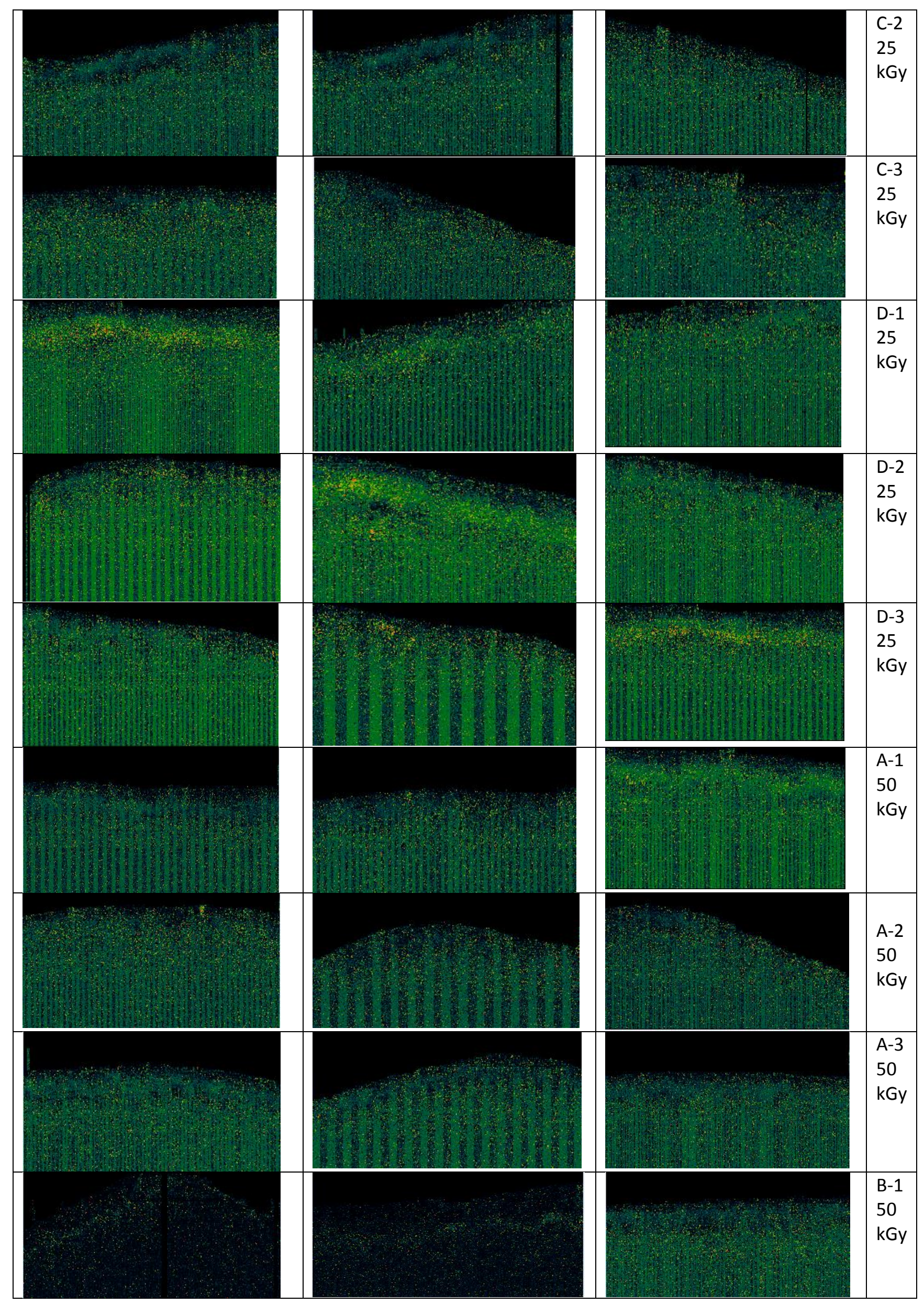




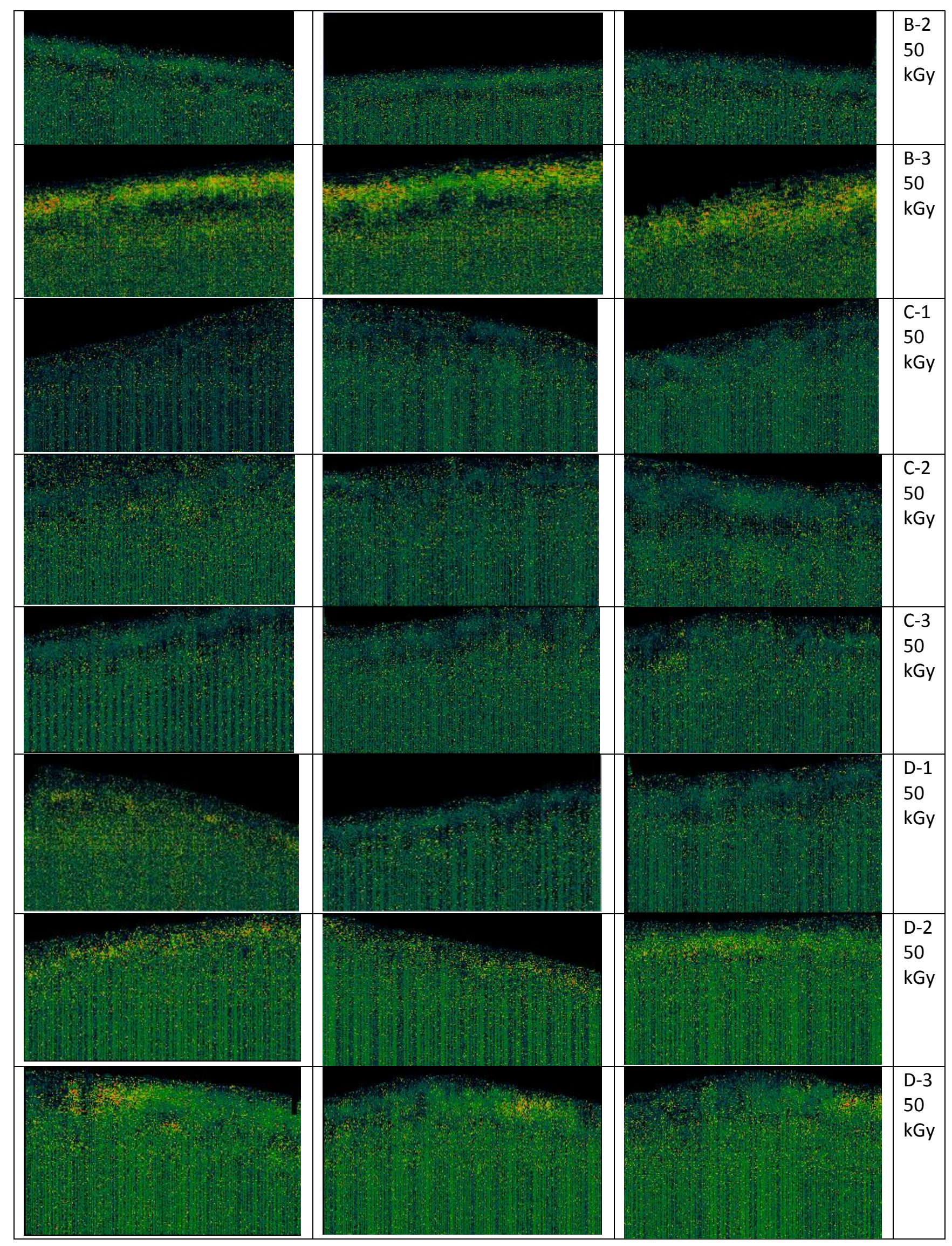




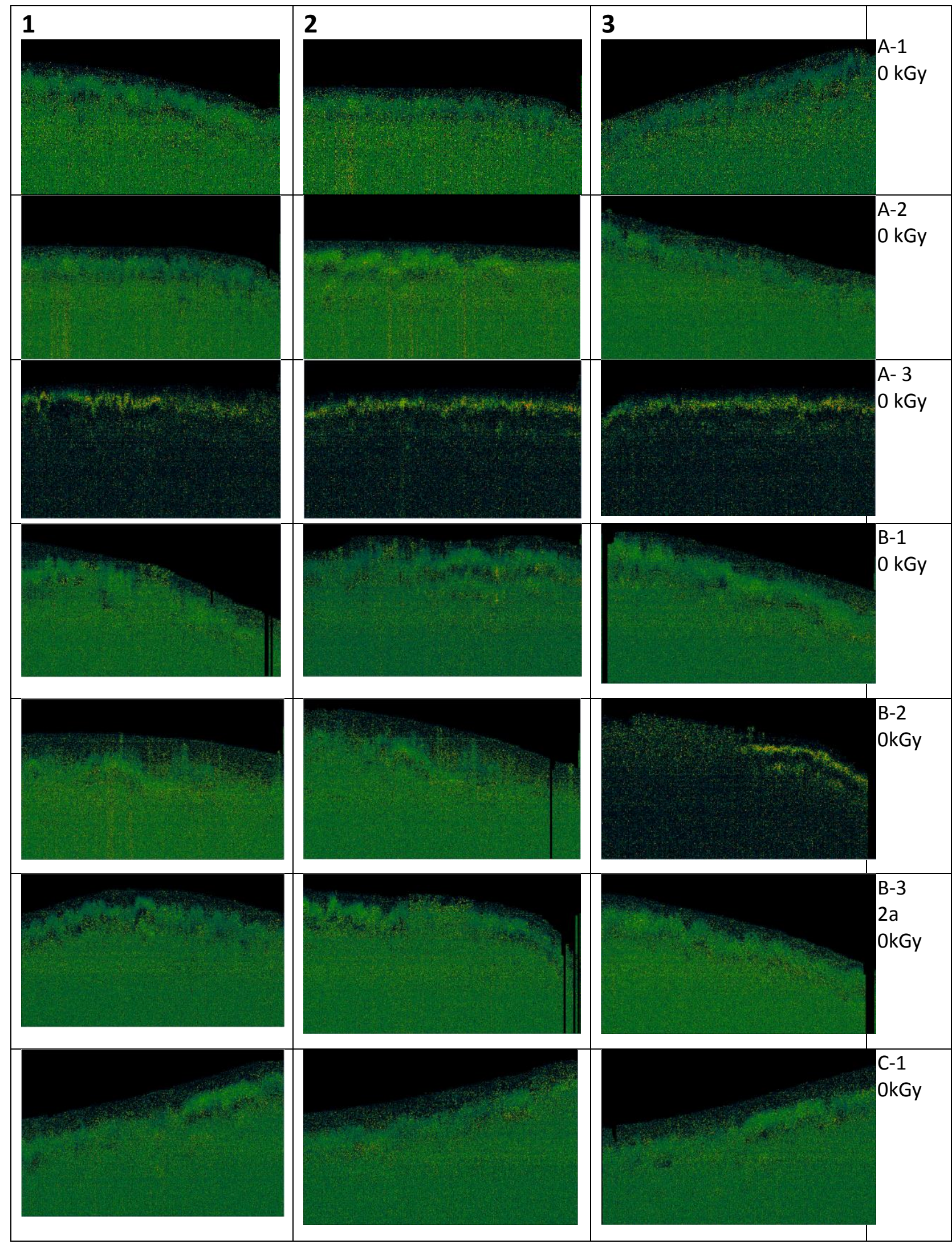



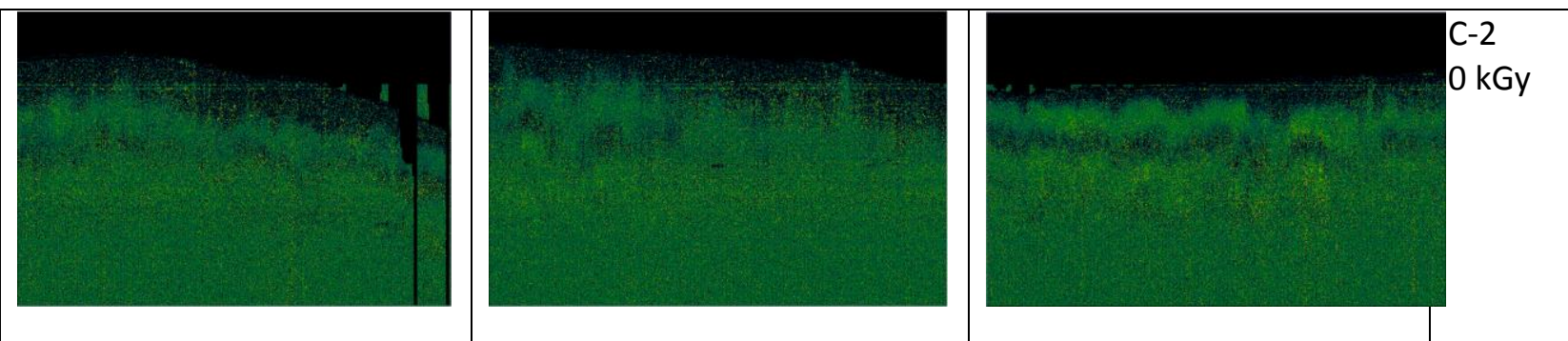

APÊNDICE 2 - Imagens das amostras liofilizadas obtidas em diferentes posições (1-3) por Tomografia por Coerência Óptica sensível à polarização

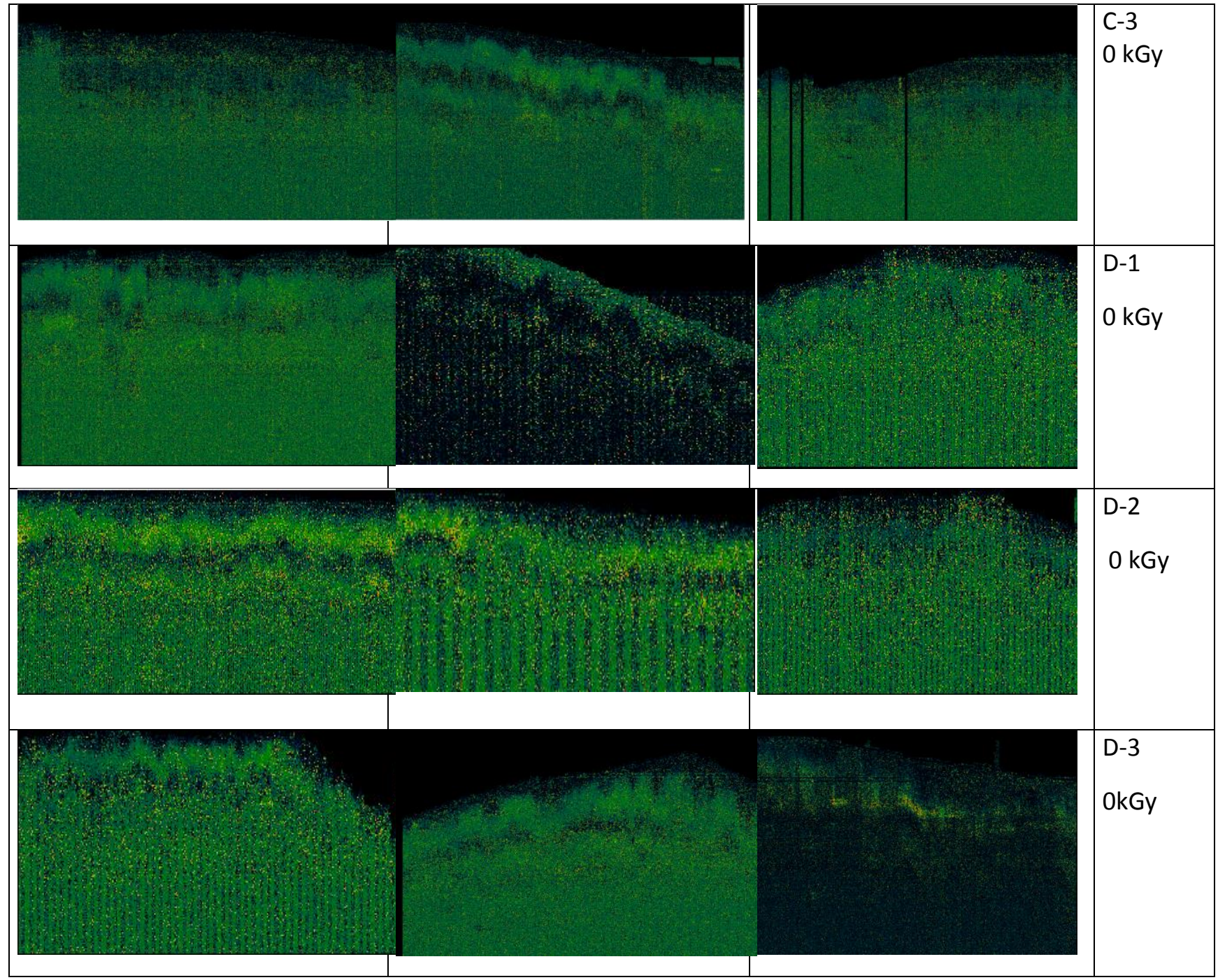




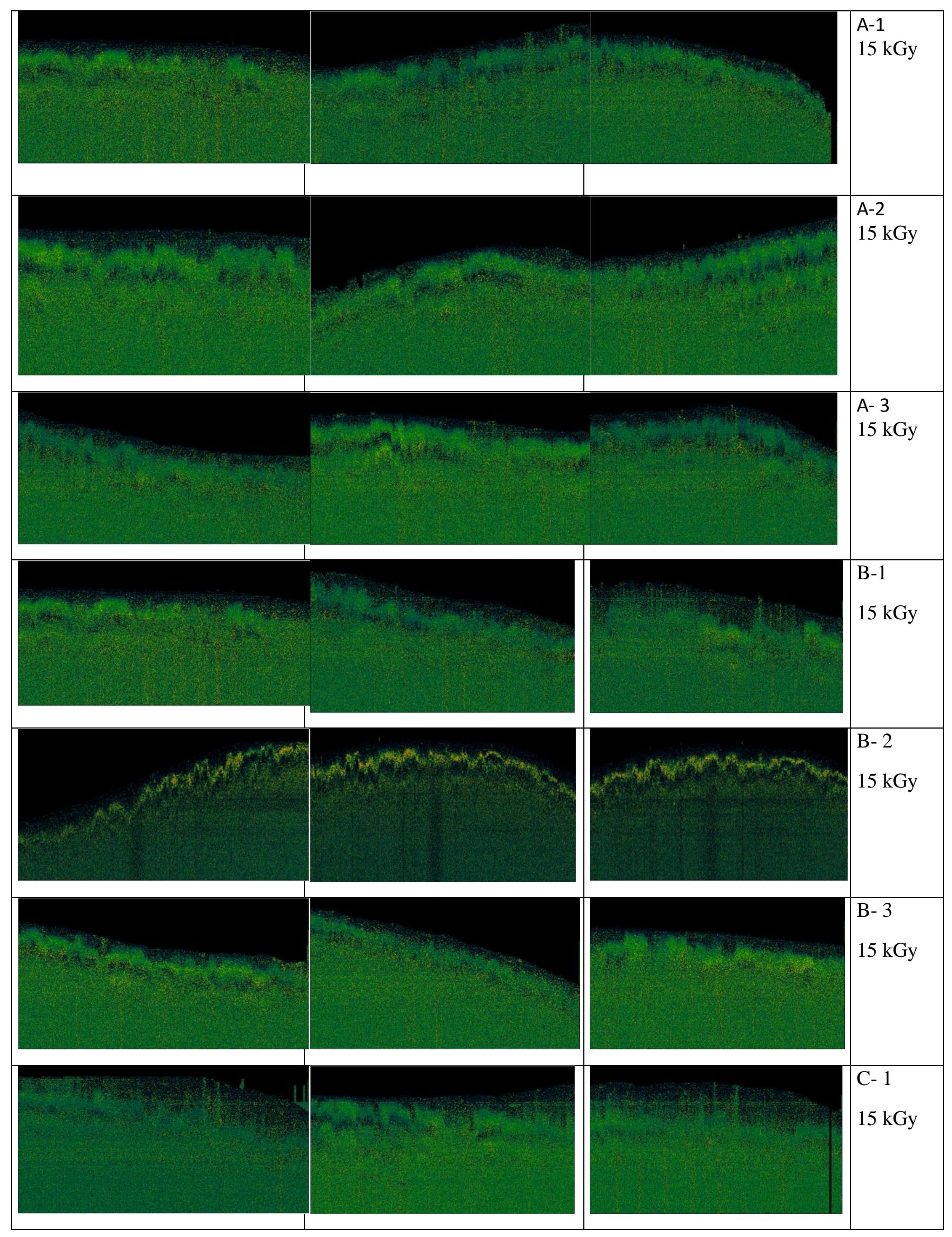




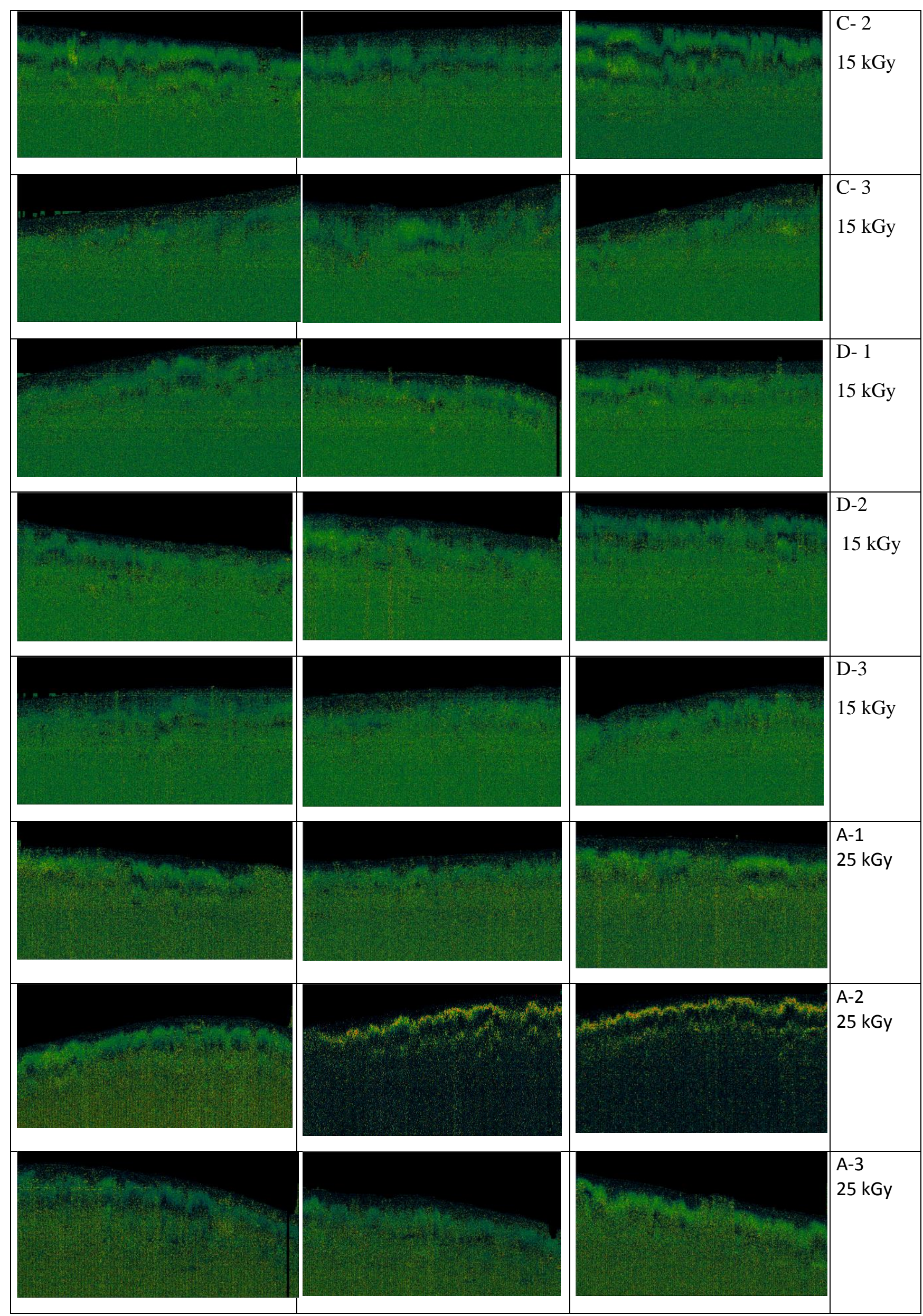




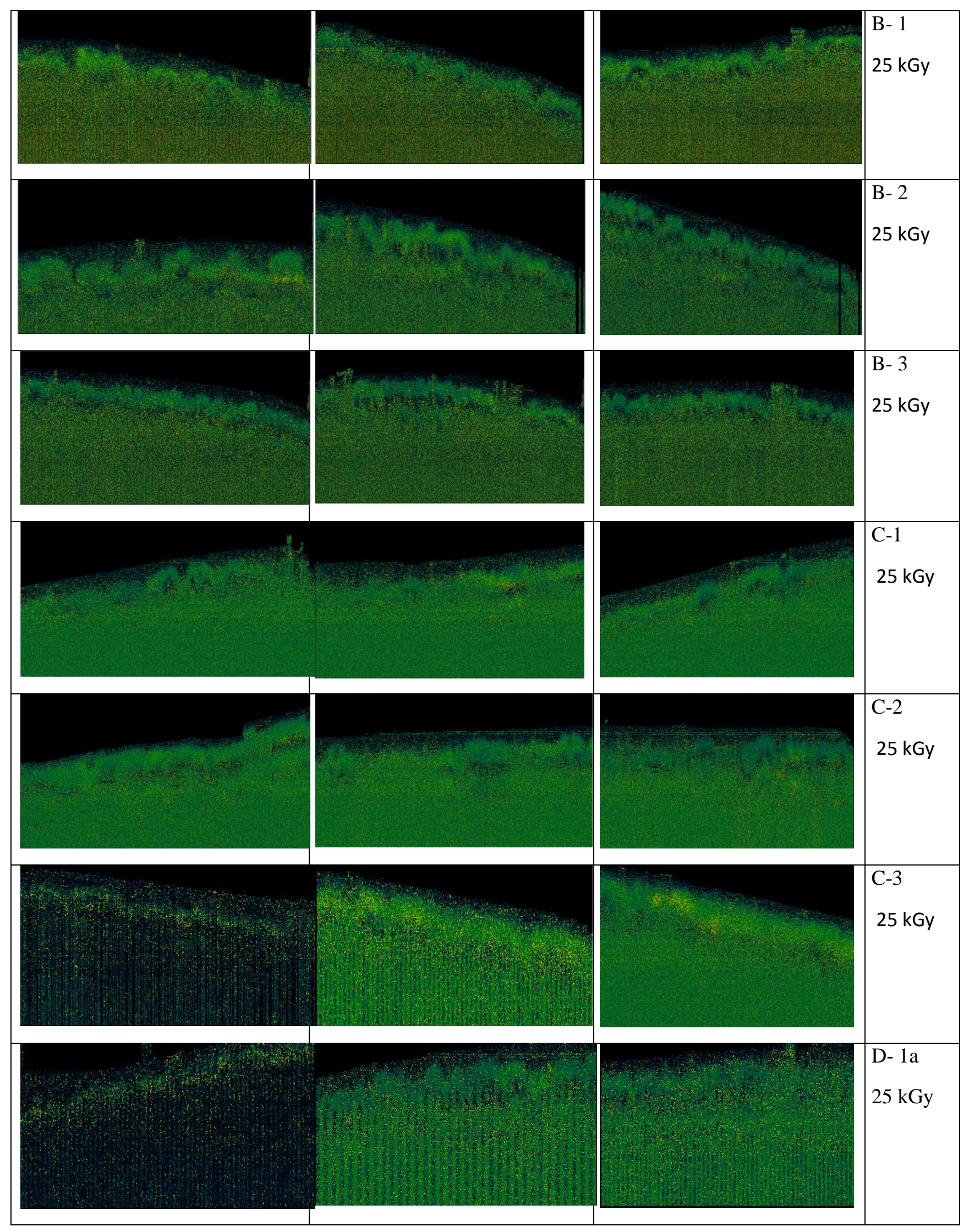




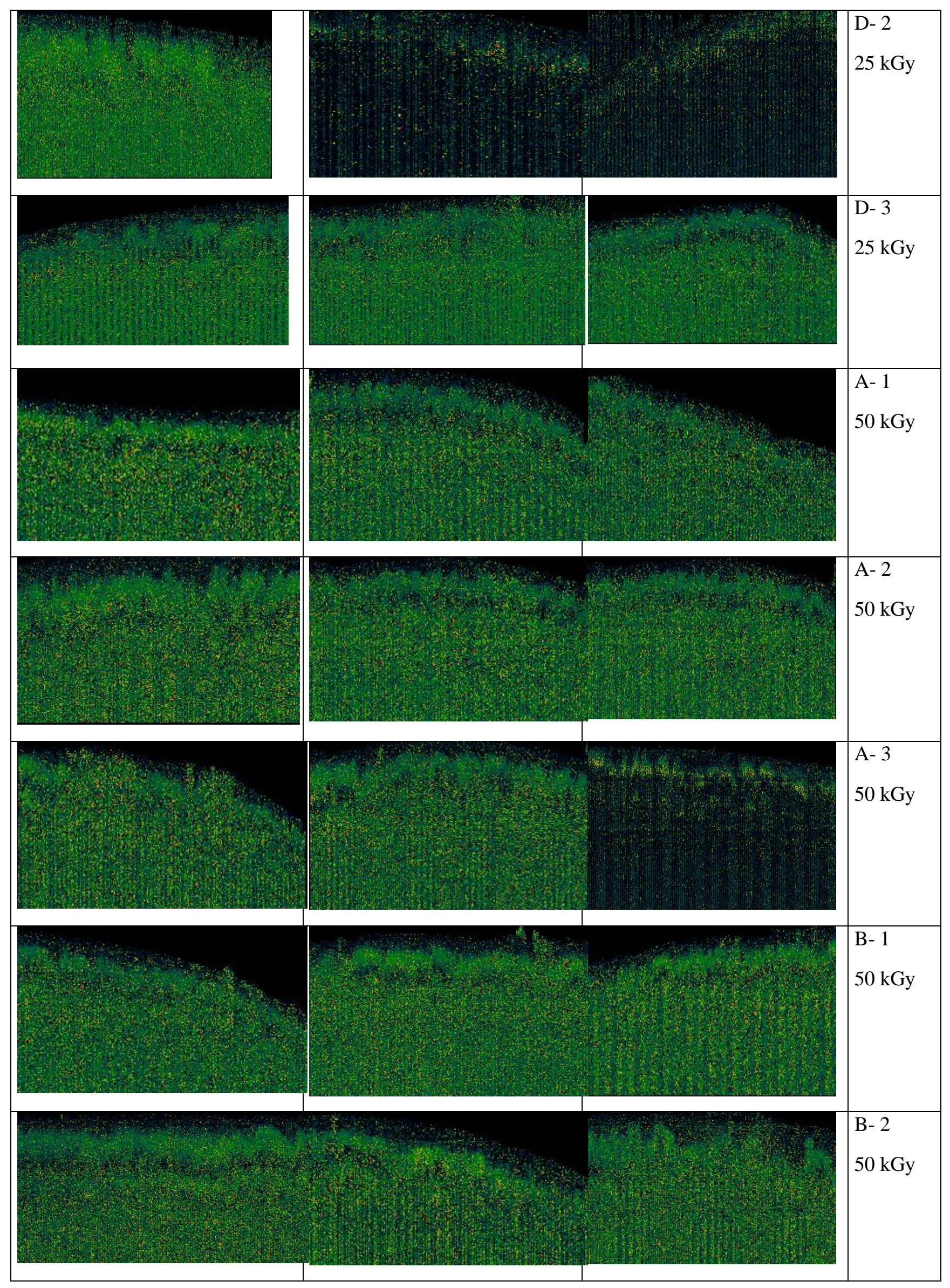




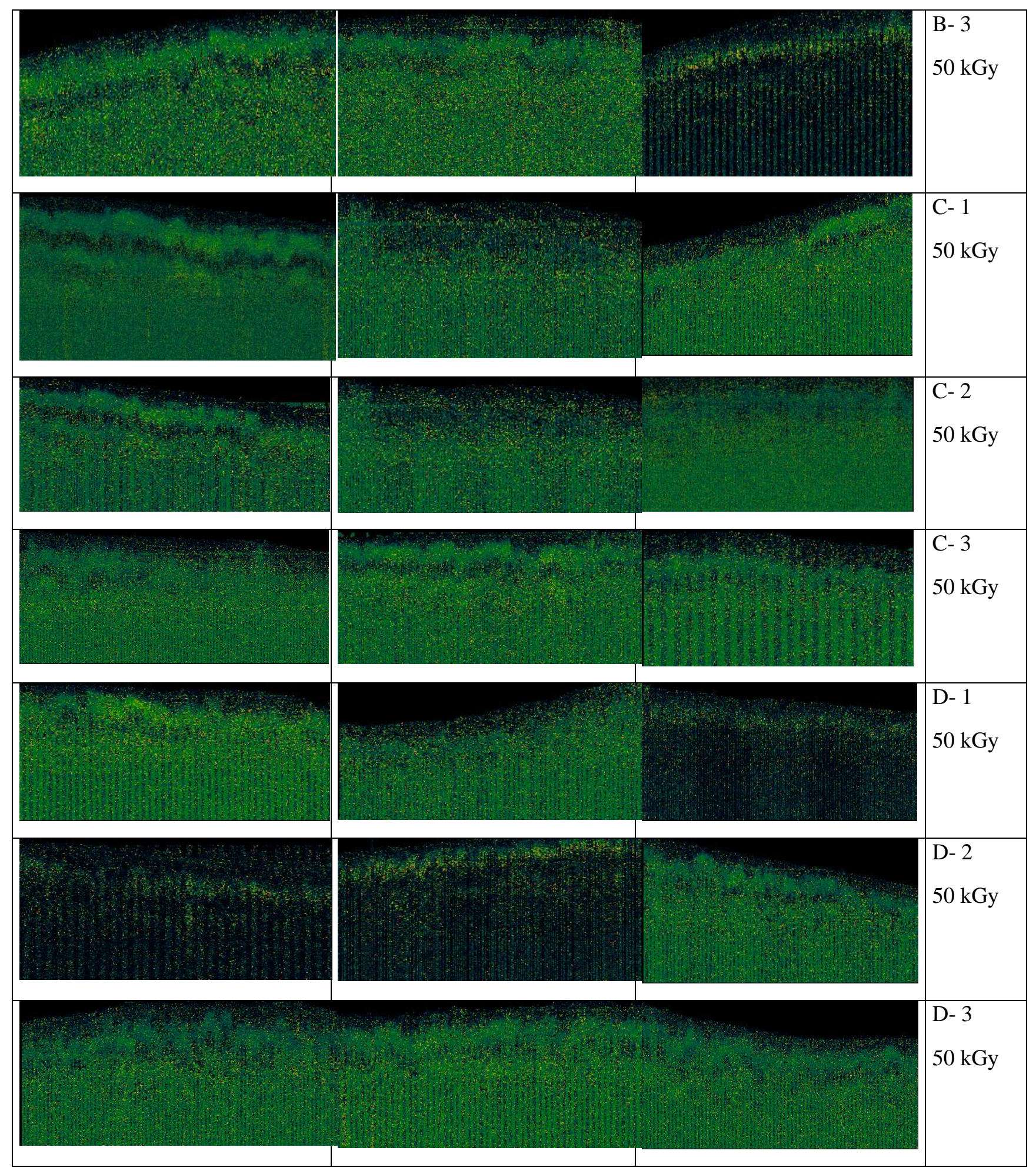




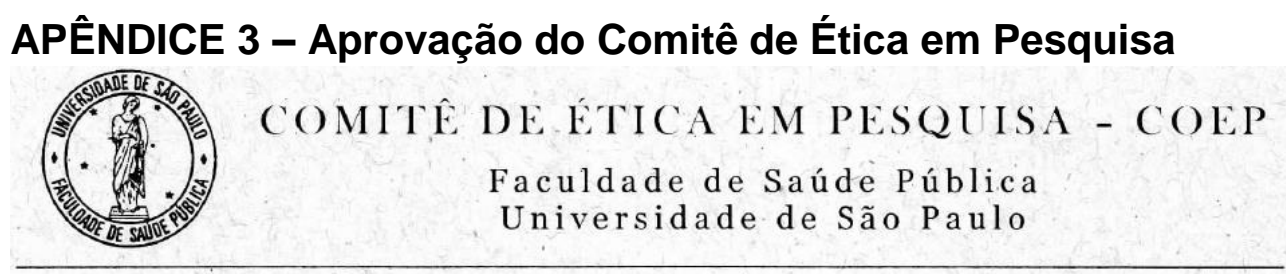

OF.COEP/013/12

31 de janeiro de 2012.

Prezadas pesquisadora e orientadora,

O Comitê de Ética em Pesquisa da Faculdade de Saúde Pública da Universidade de São Paulo, em sua 1. a/12 Sessão Ordinária, realizada em 27/01/2012, analisou de acordo com a Resolução n. ${ }^{\circ}$ 196/96 do Conselho Nacional de Saúde e suas complementares, o protocolo de pesquisa n..$^{\circ} 2311$, intitulado "AVALIAÇÃO MORFOLÓGICA E BIOMECÂNICA DOS EFEITOS DA RADIAÇÃO GAMA EM OSSO HUMANO LIOFILIZADO OU CONGELADO", do grupo III, sob responsabilịdade da pesquisadora Stefany Plumeri Santin e orientação da Professora Monica Beatriz Mathor, considerando-o APROVADO.

Cabe lembrar que, de acordo com a Res. CNS 196/96, são deveres do(a) pesquisador(a): 1) Comunicar de imediato qualquer alteração no projeto e aguárdar manifestação deste Comitê de Ética em Pesquisa para dar continuidade à pesquisa; 2) Manter sob sua guarda e em local seguro, pelo prazo de 5 (cinco) anos, os dados da pešquisa, contendo fichas individuais e todos os demais documentos recomendados pelo COEP, no caso eventual auditoria; 3) Comunicar̀ formalmente a este Comitê por ocasiāo do encerramento da pesquisa; 4) Elaborar e apresentar relatórios parciais e final; 5) Justificar perante o COEP interrupção do projeto ou a não publicação dos resultados.

Atenciosamente,

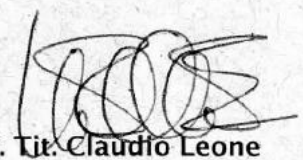

Prof. tit. Claurdio Leone

Coordenador do Comitê de Ética em Pesquisa - FSP/USP

Ilm. ${ }^{\text {a Sr}}{ }^{\text {a }}$

Prof. ${ }^{a}$ Dr. ${ }^{a}$ Monica Beatriz Mathor

Centro de Tecnologia das Radiaçōes - CTR - IPEN

Av. Dr. Arnaldo, 715 - Cerqueira Césąr - CEP 01246-904-São Paulo - SP Contato: (55 11) 30617779 | coep@fsp.usp.br | www.fsp.usp.br 


\section{APÊNDICE 4 - Legislação para utilização de tecidos biológicos em pesquisa}

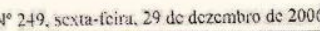

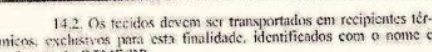

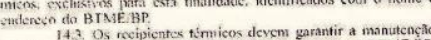

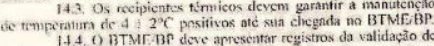

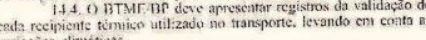

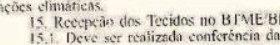

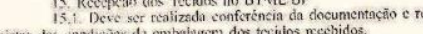

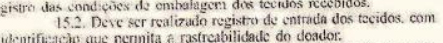

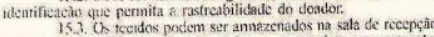

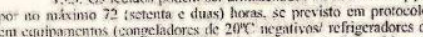

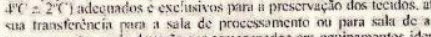

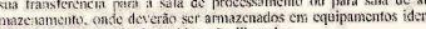

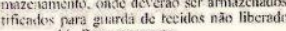

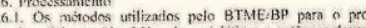

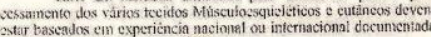
$\mathrm{cm}$ literatuma $\mathrm{c}$ descritos $\mathrm{cm}$ POP:

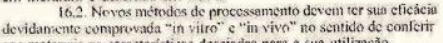

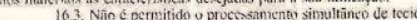
de mais de un doador na mesma sala de processamenro. 16.4. Nåa o permintido o processancento simultanco de

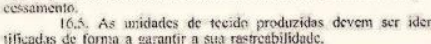

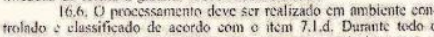

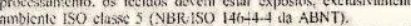

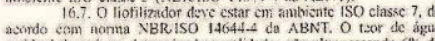

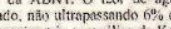
de grasinintertia ou andilise de Ka teagem deve assegurar este teor de unida

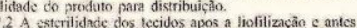

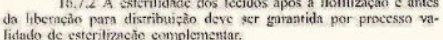

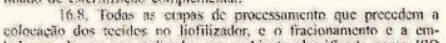

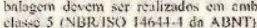

160. Tockins as clapes $\mathrm{c}$ kates de insumes utilizatos no pro.

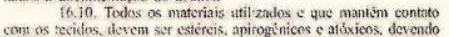

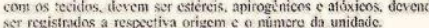

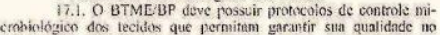
momweto da sal liberachio.

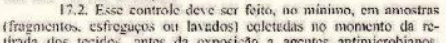

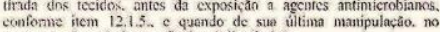

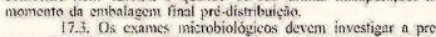

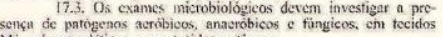

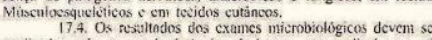
amalissades

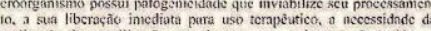

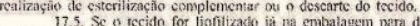

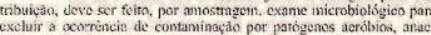

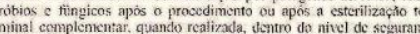
(SAL) i t

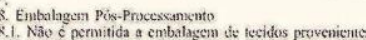

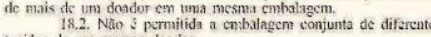
tecides de um necsmo doador.
19.3 A combahagen deve ser realizada dentro do espaco

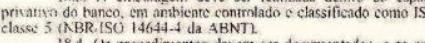

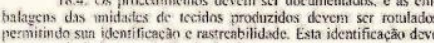

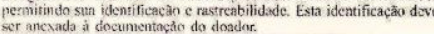

Diário Oficial da União - Seção 1

18.5. As pccas devem ser acondicionadas en cenbalagens

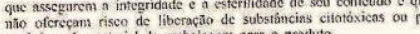

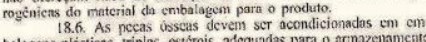

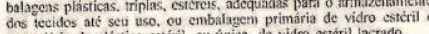

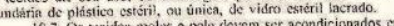
minatagens plasticas, diplas, estereis adcquadas para o armazcenacrerii, com socundíria de plistico cstcrit.

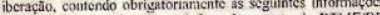

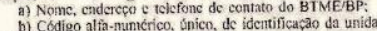

c) Tipo de tecido (p. ex: pele; osse; cartilagem): vado, liafilizado, cuns glicerol, ecc); e) Medida enn ífea, nassa, gramas out medidas lincares par

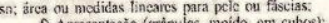

e) Dara de validade (dian, més e ano);

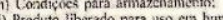

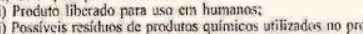

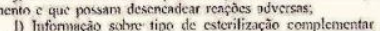
praze de validate: 18.8 .1 . Informar em rónulo adicional guando recido for do tinado ì pesquisa ou ctrsina,
19 . Examc radioticgico

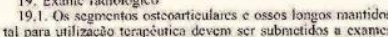

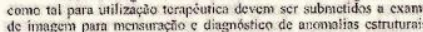
192 Estes exances devem ser arquivados fisicannente oul

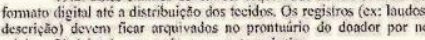

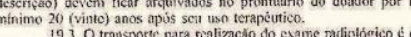

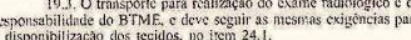

20. Esterilizacia Complementar
20.1. O BTMEBPP pode utilizar tienicas de esterilizacio

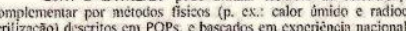
internacional docuncentada na liecratura.
20.2. A dose de radiosteriliząáo deve ser centificiuda pol

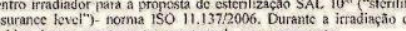

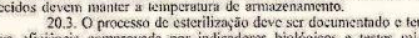
tia effivitincia comproveda por indicadores biológicos e tesses n $n$ 20.4. O transporte para a coterilizechio complementar is para o a acondicionamento dos tectido, como doscrito no itenn 24.1 . 21. Armazznamento
21.1. A forma de amazonamento deve ser definita em POP dos em experiéncia nacional. internacional c valiciada pelo bance 21.2. Os tecidos crioprestrvados, com ou sem crippres

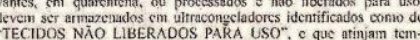
21.3. Os tecidens criogneservados, $\mathrm{sem}$ ou $\mathrm{sem}$ erioproses

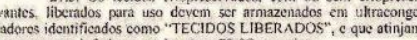

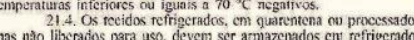

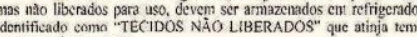
craturas de $4 \pm 2{ }^{\circ} \mathrm{C}$

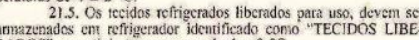

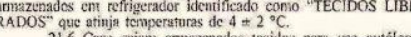

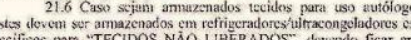

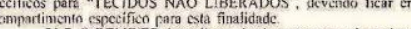

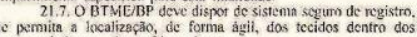

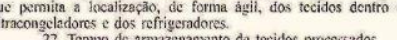

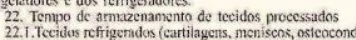

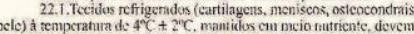

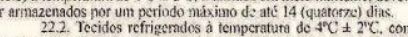

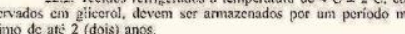

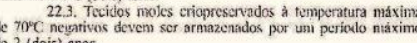

JSSY $1677-7042$

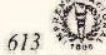

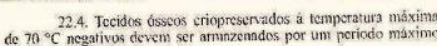

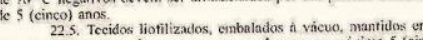

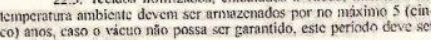
23. Disponibilizacsion dos tecidos

disponibilizados para us tador autorizado pelo CGSNT contenda informaçócs sobre o recepto

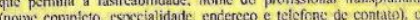

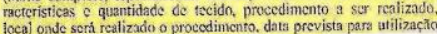
elecide 23.2. Os tocidos somente seráo disponibilizados para pes-

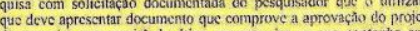

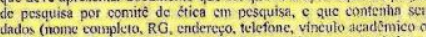
profissional), local onde scri realizado o projecto. caraeteristicas

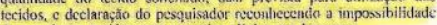
de usa destes tecidos para pesquisa clinica em litumanos.
23.3 . Os tecidos sonente seào disponibilizudos pars ensín

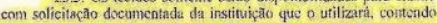

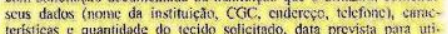

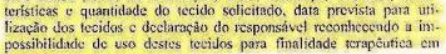
23.4. Deve ser acconpanthala de instruęes 1ścnicas, com

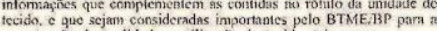

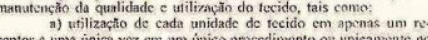

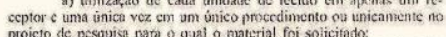

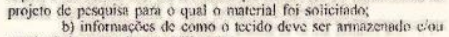
manipulado antes da sua utilizaçán:

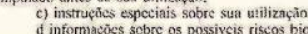

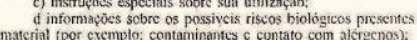
c) alera para a obrigatoricdade de informar ao banteo e érghans

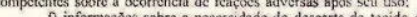

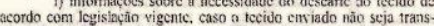
plantado tofal ou parcialmente, ou uilizado total ou parcialmente no projecto de pesquisa ou censino para o qual foi solicitado. Dese ser justificativa. 24 . Acondicionamento $\mathrm{C}$ tansporte do BTME/BP para o serviço que utilizará os fecidos
24.1 . 0 8TMEBPP fica responsivel em acondiciongr of te-

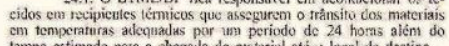

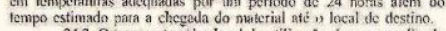

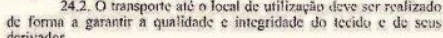

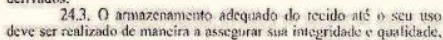

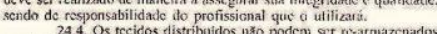
ou destinados o usn ternpeutico en outro peceptor, bem como ao uso

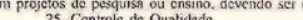
25.1. O BTME/BP deve desenvolver un programa de con-

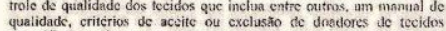
especificos, registrus completos descie a eatrevista atć a distribuicazo

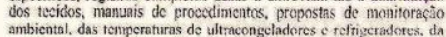

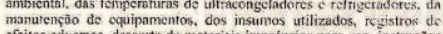

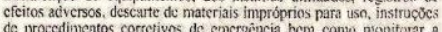

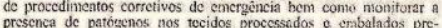
viamerate is as sua liberacio para uso gistro lógico que possibilite seu rastreaniento a qualquer momertit. petertes para a ocortíncia de efétios adversos após o uso terapécurico. 26. Descarte de residuos

de valicade iencido ou impreprios mara

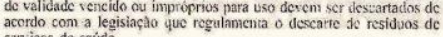

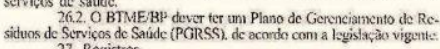
27. Registros
27.1. O BTMEBBP deve ter un sistema de registro apro-

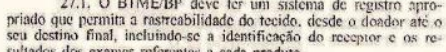


1)

110

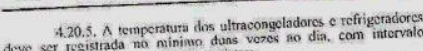

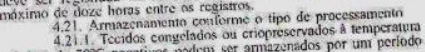

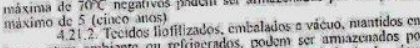

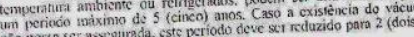

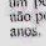

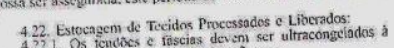

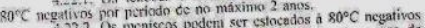

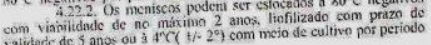

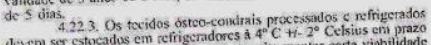

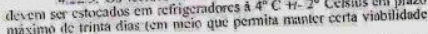

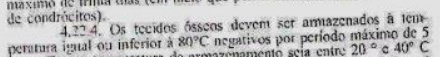

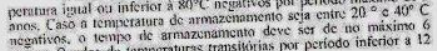

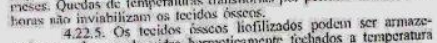

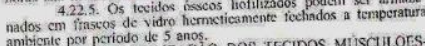

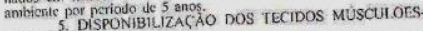

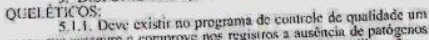

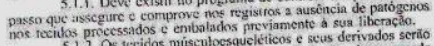

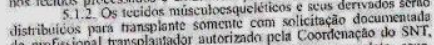

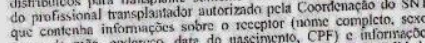

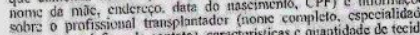

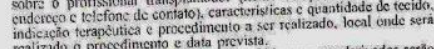

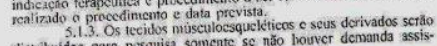

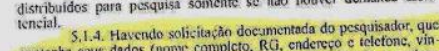

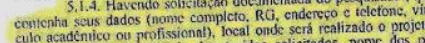

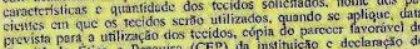

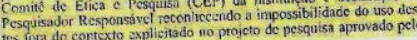

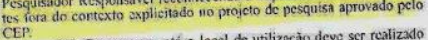

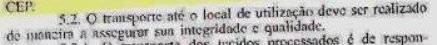

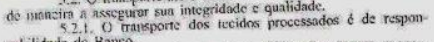

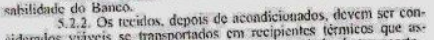

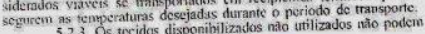

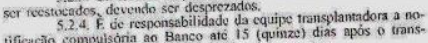

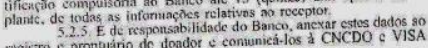

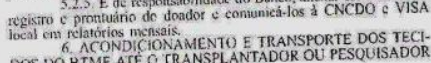

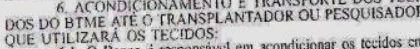

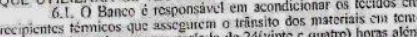

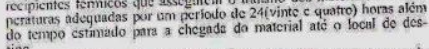

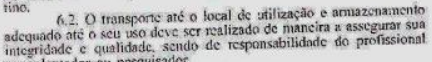

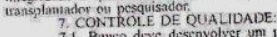

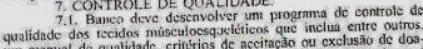

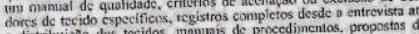

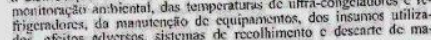

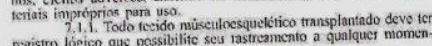
10. 7.2 Deve existir sistema de netificactio a CNCDOSNT

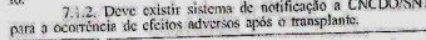

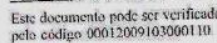

Diário Oficial da Uniāo - Seçăo 1

8. DESCARTE DE RESiDUTOS

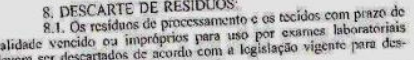

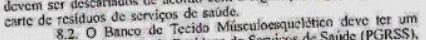

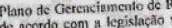

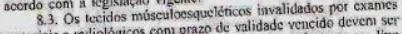

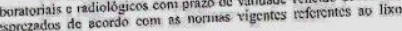

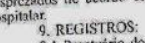

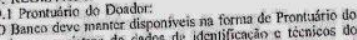

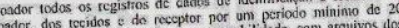

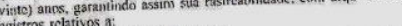

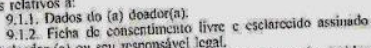

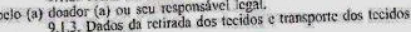
10 Banco. 9.1.4. Registros do processammento, incluindo a identificaçio

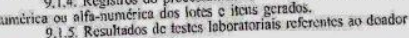

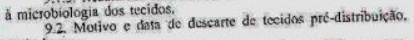

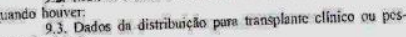

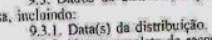

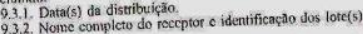

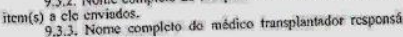

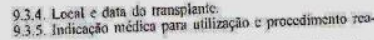

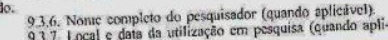

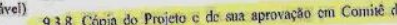

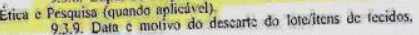

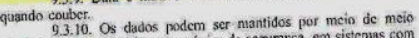

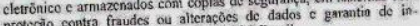

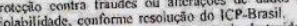

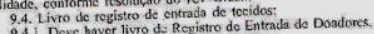

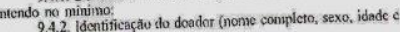

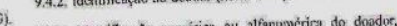

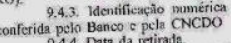

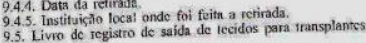

Intikes:

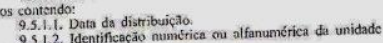
ido distributalai

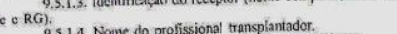

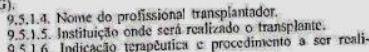

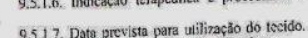

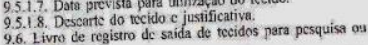

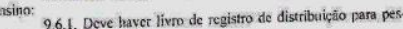

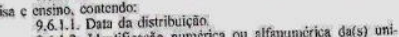

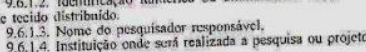

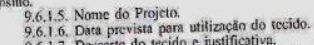
9.6.1.1. Descartc do tecido c justificativa

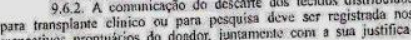
viva.

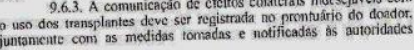

N* 208, sexta-feira, 30 de ourubro de 2009

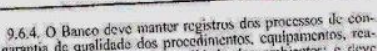

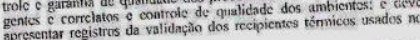

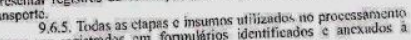

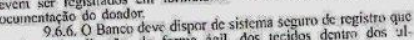

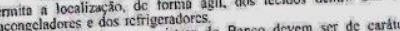

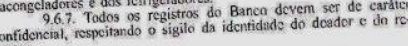
SISTEMA NACIONAL. DE TRANSPLANTES REGULAMENTO TÉCNICO ANEXO XIY

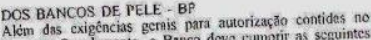

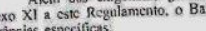

1. ER EUPIPES TECNICAS

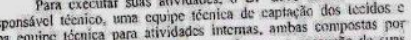

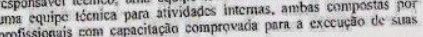

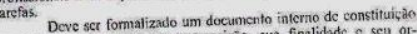

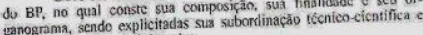

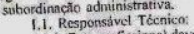

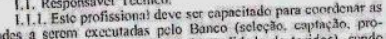

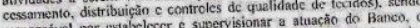

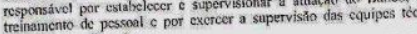

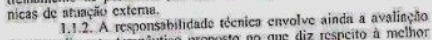

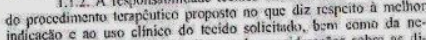

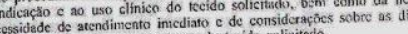

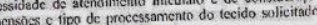

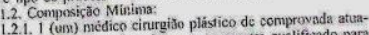

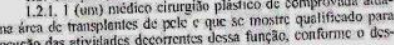

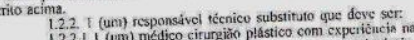

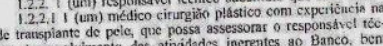

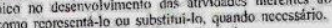

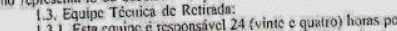

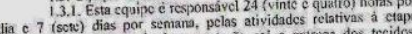

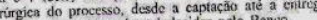

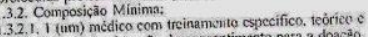

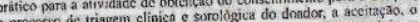

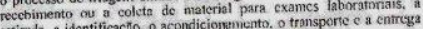

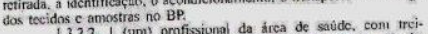

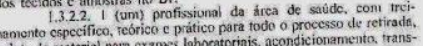

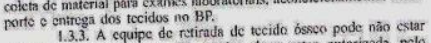

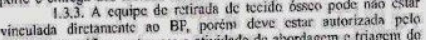

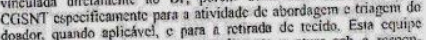

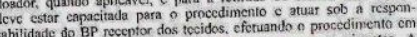

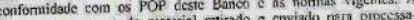

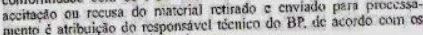

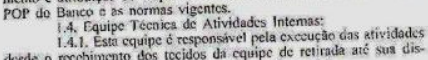

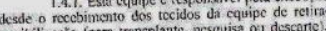

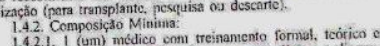

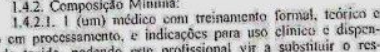

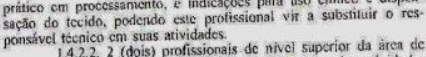

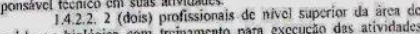

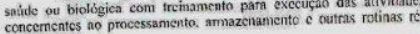

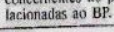

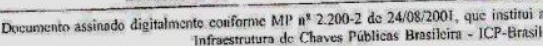

